\title{
Contributions to New Jersey Geology
}

A. The Lake Hopatcong Intrusive Suite (Middle Proterozoic) of the New Jersey Highlands

B. The High Point Member (Upper Ordovician) of the Martinsburg Formation in Northern New Jersey and Southeastern New York

C. The Mount Eve Granite (Middle Proterozoic) of Northern New Jersey and Southeastern New York

D. The Byram Intrusive Suite of the Reading Prong-Age and Tectonic Environment

\section{U.S. GEOLOGICAL SURVEY BULLETIN 1952}

Prepared in cooperation with the New Jersey Geological Survey

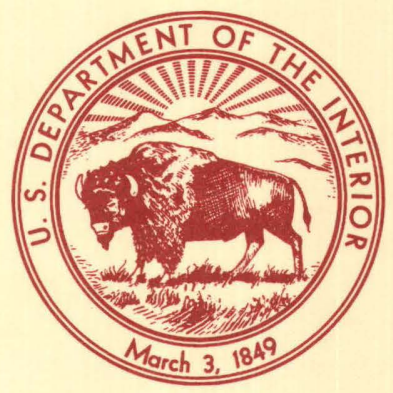




\section{AVAILABILITY OF BOOKS AND MAPS OF THE U.S. GEOLOGICAL SURVEY}

Instructions on ordering publications of the U.S. Geological Survey, along with the last offerings, are given in the current-year issues of the monthly catalog "New Publications of the U.S. Geological Survey." Prices of available U.S. Geological Survey publications released prior to the current year are listed in the most recent annual "Price and Availability List." Publications that are listed in various U.S. Geological Survey catalogs (see back inside cover) but not listed in the most recent annual "Price and Availability List" are no longer available.

Prices of reports released to the open files are given in the listing "U.S. Geological Survey Open-File Reports," updated monthly, which is for sale in microfiche from the U.S. Geological Survey, Books and Open-File Reports Section, Federal Center, Box 25425, Denver, CO 80225. Reports released through the NTIS may be obtained by writing to the National Technical Information Service, U.S. Department of Commerce, Springfield, VA 22161; please include NTIS report number with inquiry.

Order U.S. Geological Survey publications by mail or over the counter from the offices given below.

\section{BY MAIL}

\section{Books}

Professional Papers, Bulletins, Water-Supply Papers, Techniques of Water-Resources Investigations, Circulars, publications of general interest (such as leaflets, pamphlets, booklets), single copies of periodicals (Earthquakes \& Volcanoes, Preliminary Determination of Epicenters), and some miscellaneous reports, including some of the foregoing series that have gone out of print at the Superintendent of Documents, are obtainable by mail from

\section{U.S. Geological Survey, Books and Open-File Reports Section Federal Center, Box 25425 Denver, CO 80225}

Subscriptions to periodicals (Earthquakes \& Volcanoes and Preliminary Determination of Epicenters) can be obtained ONLY from

Superintendent of Documents

U.S. Government Printing Office Washington, DC 20402

(Check or money order must be payable to Superintendent of Documents.)

\section{Maps}

For maps, address mail orders to

\section{U.S. Geological Survey, Map Distribution \\ Federal Center, Box 25286 \\ Denver, CO 80225}

Residents of Alaska may order maps from

\author{
U.S. Geological Survey, Map Distribution \\ New Federal Building - Box 12 \\ 101 Twelfth Ave., Fairbanks, AK 99701
}

\section{OVER THE COUNTER}

\section{Books}

Books of the U.S. Geological Survey are available over the counter at the following U.S. Geological Survey offices, all of which are authorized agents of the Superintendent of Documents:

- ANCHORAGE, Alaska-4230 University Dr., Rm. 101

- ANCHORAGE, Alaska-605 West 4th Ave., Rm. G-84

- DENVER, Colorado-Federal Bldg., Rm. 169, 1961 Stout St.

- LOS ANGELES, California-Federal Bldg., Rm. 7638, 300 North Los Angeles St.

- MENLO PARK, California-Bldg. 3, Rm. 3128, 345 Middlefield Rd.

- RESTON, Virginia-National Center, Rm. 1C402, 12201 Sunrise Valley Dr.

- SALT LAKE CITY, Utah-Federal Bldg., Rm. 8105, 125 South State St.

- SAN FRANCISCO, California-Customhouse, Rm. 504, 555 Battery St.

- SPOKANE, Washington-U.S. Courthouse, Rm. 678, West 920 Riverside Ave.

- WASHINGTON, DC-U.S. Department of the Interior Bldg., Rm. 2650, 1849 C St., NW.

\section{Maps}

Maps may be purchased over the counter at the U.S. Geological Survey offices where books are sold (all addresses in above list) and at the following U.S. Geological Survey offices:

- ROLLA, Missouri-1400 Independence Rd.

- FAIRBANKS, Alaska-New Federal Bldg., 101 Twelfth Ave. 


\section{Contributions to New Jersey Geology}

\section{Edited by AVERY ALA DRAKE, JR.}

A. The Lake Hopatcong Intrusive Suite (Middle Proterozoic) of the New Jersey Highlands

BY AVERY ALA DRAKE, JR., and RICHARD A. VOLKERT

B. The High Point Member (Upper Ordovician) of the Martinsburg Formation in Northern New Jersey and Southeastern New York BY AVERY ALA DRAKE, JR.

C. The Mount Eve Granite (Middle Proterozoic) of Northern New Jersey and Southeastern New York

BY AVERY ALA DRAKE, JR., JOHN N. ALEINIKOFF, and RICHARD A. VOLKERT

D. The Byram Intrusive Suite of the Reading Prong-Age and Tectonic Environment By AVERY ALA DRAKE, JR., JOHN N. ALEINIKOFF, and RICHARD A. VOLKERT

Prepared in cooperation with the New Jersey Geological Survey

\section{U.S. GEOLOGICAL SURVEY BULLETIN 1952}




\title{
U.S. DEPARTMENT OF THE INTERIOR \\ MANUEL LUJAN, Jr., Secretary
}

\section{U.S. GEOLOGICAL SURVEY}

\author{
Dallas L. Peck, Director
}

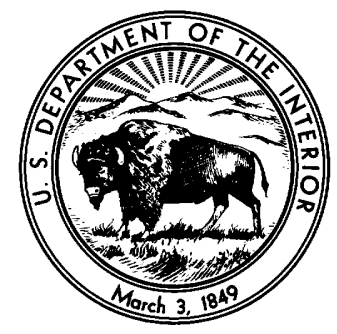

Any use of trade, product, or firm names in this publication is for descriptive purposes only and does not imply endorsement by the U.S. Government

For sale by the

Books and Open-File Reports Section

U.S. Geological Survey

Federal Center, Box 25425

Denver, CO 80225

Library of Congress Cataloging in Publication Data

Contributions to New Jersey geology / edited by Avery Ala Drake, Jr.

p. $\quad$ cm. - (U.S. Geological Survey bulletin ; 1952)

Includes bibliographical references.

Supt. of Docs. no.: 1 19.3:1952

1. Geology-New Jersey. 2. Geology-New York (State) I. Drake, Avery Ala, 1927- . II. Series.

QE75.B9 no. 1952

[QE141]

$557.3 \mathrm{~s}-\mathrm{dc} 20$

[557.49] 


\section{CONTENTS}

(Letters indicate the chapter)

(A) The Lake Hopatcong Intrusive Suite (Middle Proterozoic) of the New Jersey Highlands, by Avery Ala Drake, Jr., and Richard A. Volkert

(B) The High Point Member (Upper Ordovician) of the Martinsburg Formation in Northern New Jersey and Southeastern New York, by Avery Ala Drake, Jr.

(C) The Mount Eve Granite (Middle Proterozoic) of Northern New Jersey and Southeastern New York, by Avery Ala Drake, Jr., John N. Aleinikoff, and Richard A. Volkert

(D) The Byram Intrusive Suite of the Reading Prong-Age and Tectonic Environment, by Avery Ala Drake, Jr., John N. Aleinikoff, and Richard A. Volkert 
Chapter A

The Lake Hopatcong Intrusive Suite (Middle Proterozoic) of the New Jersey Highlands

By AVERY ALA DRAKE, JR., U.S. Geological Survey, and RICHARD A. VOLKERT, New Jersey Geological Survey

Prepared in cooperation with the

New Jersey Geological Survey

U.S. GEOLOGICAL SURVEY BULLETIN 1952

CONTRIBUTIONS TO NEW JERSEY GEOLOGY 


\title{
CONTENTS
}

\author{
Abstract A1 \\ Introduction A1 \\ Byram Intrusive Suite A1 \\ Lake Hopatcong Intrusive Suite A4 \\ Regional Relations $\quad$ A7 \\ References Cited A8
}

\section{FIGURES}

A1, A2. Maps showing:

A1. Distribution of rocks older than 1 billion years in Eastern North America A2

A2. Distribution of Middle Proterozoic rocks of the Reading Prong in New Jersey and immediately adjacent New York $\mathbf{A 3}$

A3. Normative feldspar plot of rocks of the Byram Intrusive Suite A4

A4. Quartz-alkali feldspar-plagioclase plot of rocks of the Lake Hopatcong Intrusive Suite A5

A5. Normative feldspar plot of rocks of the Lake Hopatcong Intrusive Suite A5 A6, A7. Plots comparing:

A6. Bulk chemistry of the Lake Hopatcong and Byram Intrusive Suites A6

A7. Normative mineralogy of rocks of the Lake Hopatcong and Byram Intrusive Suites A6

A8. Normative feldspar plot of hornblende granite and alaskite from the Adirondack massif A7

A9. AFM plot comparing rocks of the Byram Intrusive Suite with hornblende granite and alaskite from the Adirondack massif $\mathbf{A 7}$

A10. Normative feldspar plot of quartz syenites from the Adirondack massif $\mathbf{A 8}$

\section{TABLES}

A1. Chemical analyses and CIPW norms of rocks of the Byram Intrusive Suite A4

A2. Chemical analyses and CIPW norms of rocks of the Lake Hopatcong Intrusive Suite A5

A3. Fe-Mg ratios of some rocks of the Lake Hopatcong and Byram Intrusive Suites $\quad \mathbf{A 7}$ 


\title{
The Lake Hopatcong Intrusive Suite (Middle Proterozoic) of the New Jersey Highlands
}

\author{
By Avery Ala Drake, Jr., and Richard A. Volkert
}

\begin{abstract}
Detailed geologic mapping of the entire New Jersey Highlands has shown that quartz-poor and granitic rocks characterized by clinopyroxene and either mesoperthite or microantiperthite occur throughout. These rocks are particularly abundant in the Lake Hopatcong area and are included in the Lake Hopatcong Intrusive Suite (new name). They occur in large sheets thought to have been emplaced during the Girenville orogeny $(1.1 \mathrm{Ga})$. The Lake Hopatcong rocks have not been recognized either in Pennsylvania or in southeastern New York, but are similar to quartz syenites in the Adirondack massif of New York.
\end{abstract}

\section{INTRODUCTION}

The New Jersey Highlands is the middle segment of the Reading Prong, one of the major external massifs of Middle Proterozoic rocks in the Appalachian orogen of Eastern North America (fig. A1). These highlands are continuous with the Durham and Reading Hills to the west and the Hudson Highlands to the east, the other segments of the Reading Prong (Drake and others, 1988). The Middle Proterozoic rocks of the Reading Prong consist of intrusive rocks and attendant migmatites, quartzofeldspathic and calcareous metasedimentary rocks, sodium-rich rocks of probable volcanic origin, and hypersthene-bearing charnockitic rocks of problematic origin. The distribution of these rocks in the New Jersey Highlands is shown in figure A2.

Traditionally, the bulk of the Middle Proterozoic rocks in the New Jersey Highlands were considered to be intrusive and were divided into Byram "granite gneiss" (feldspar, dominantly potassic feldspar), Losee "diorite gneiss" (feldspar, dominantly plagioclase), and Pochuck "gabbro gneiss" (mafic rocks). These units were thought to grade into each other through intermediate forms (Spencer and others, 1908; Bayley, 1941). Some metasedimentary units were recognized, however, including the Franklin Limestone (Spencer and others, 1908) and the Pickering Gneiss near the Delaware River (Bayley, 1941). Since the

Manuscript approved for publication July 19, 1990. end of World War II, many detailed examinations have been made in New Jersey and immediately adjacent Pennsylvania and New York. The most important of these include studies by Baker and Buddington (1970), Buckwalter (1959, 1962), Dodd (1965), Drake (1969), Hague and others (1956), Hotz (1953), Offield (1967), Sims (1958), and Young $(1971,1972,1978)$. Most of these workers abandoned the classic formations in favor of more precise lithologic units.

More recent work (Drake, 1984) has shown that most of the intrusive rocks in the New Jersey Highlands belong to three suites: (1) hornblende granite, microperthite alaskite, and related rocks; (2) quartz-poor clinopyroxene-bearing rocks generally called syenite, and related clinopyroxenebearing granite; and (3) microantiperthite-bearing alaskite of complex origin. Much less abundant postkinematic Mount Eve Granite crops out in the Unionville, Pine Island, Hamburg, Wawayanda, and Newton East quadrangles (Drake and others, chap. C, this vol.) (fig. A2).

Drake (1984) redefined the name "Byram" to include the hornblende granite and associated rocks in a Byram Intrusive Suite. Although it was recognized in 1984 that the clinopyroxene rocks constitute a distinct suite of rocks, they were not formally named, as their relation to the Byram was uncertain. Recently, geologic mapping of all the 7.5-minute quadrangles in the New Jersey Highlands has been completed for the new geologic map of New Jersey. Although more detailed chemical work will be necessary to clearly establish the petrogenetic relation of the clinopyroxenebearing rocks to the Byram, it is clear that they constitute a distinct intrusive suite and deserve a formal name. They are here named the Lake Hopatcong Intrusive Suite for their abundance in the Lake Hopatcong area in the Stanhope and Dover 7.5-minute quadrangles, New Jersey (fig. A2).

\section{BYRAM INTRUSIVE SUITE}

Granitoid rocks consisting of quartz, microperthite, and oligoclase and containing varying amounts of mafic minerals (as much as 10 percent) crop out throughout the Reading Prong and constitute the Byram Intrusive Suite. 


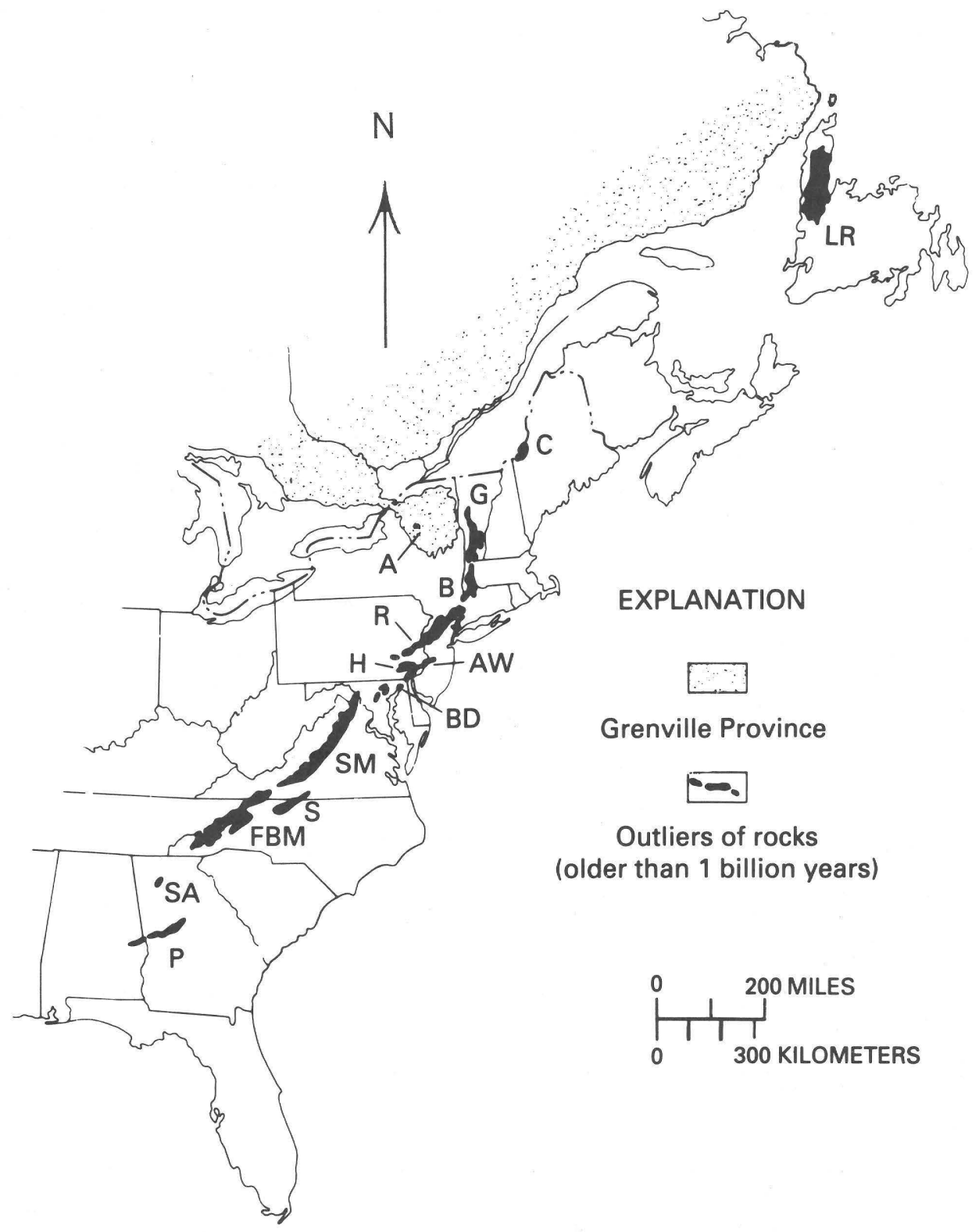

Figure A1. Distribution of rocks older than 1 billion years in Eastern North America. LR, Long Range; C, Chain Lakes massif; G, Green Mountain massif; A, Adirondack massif; B, Berkshire massif; R, Reading Prong; H, Honey Brook upland; AW, Avondale-West Chester massif; BD, Baltimore "gneiss domes"; SM, Shenandoah massif; S, Sauratown Mountains window; FBM, French Broad massif; SA, Salem Church anticline; and P, Pine Mountain window. Modified from Drake (1984).

They occur in regionally comformable sheets, but locally cut across the structure of the older rocks. They are interpreted to have been synkinematically emplaced during the Grenville orogeny (Drake, 1969, 1984; Rankin and others, 1989 , in press). These rocks are described below to allow comparison with the rocks of the Lake Hopatcong Intrusive Suite.

The Byram rocks are medium- to coarse-grained, pink to buff to bronze, gneissoid to indistinctly foliated granitoids and sparse granite gneiss. Petrographically, the
Byram consists of four different rock types: hornblende granite, alaskite, biotite granite, and hornblende syenite. The potassic feldspar is largely microcline microperthite, although some rocks contain microcline. The hornblende is largely ferrohastingsite. Regionally, the bulk of the rocks are monzogranite and syenogranite, although syenite and quartz syenite are fairly common, and alkali feldspar granite and quartz monzonite occur in some places (Drake, 1984).

Drake (1984) showed that rocks mapped as Byram have a similar chemistry from the southwestern end of the 


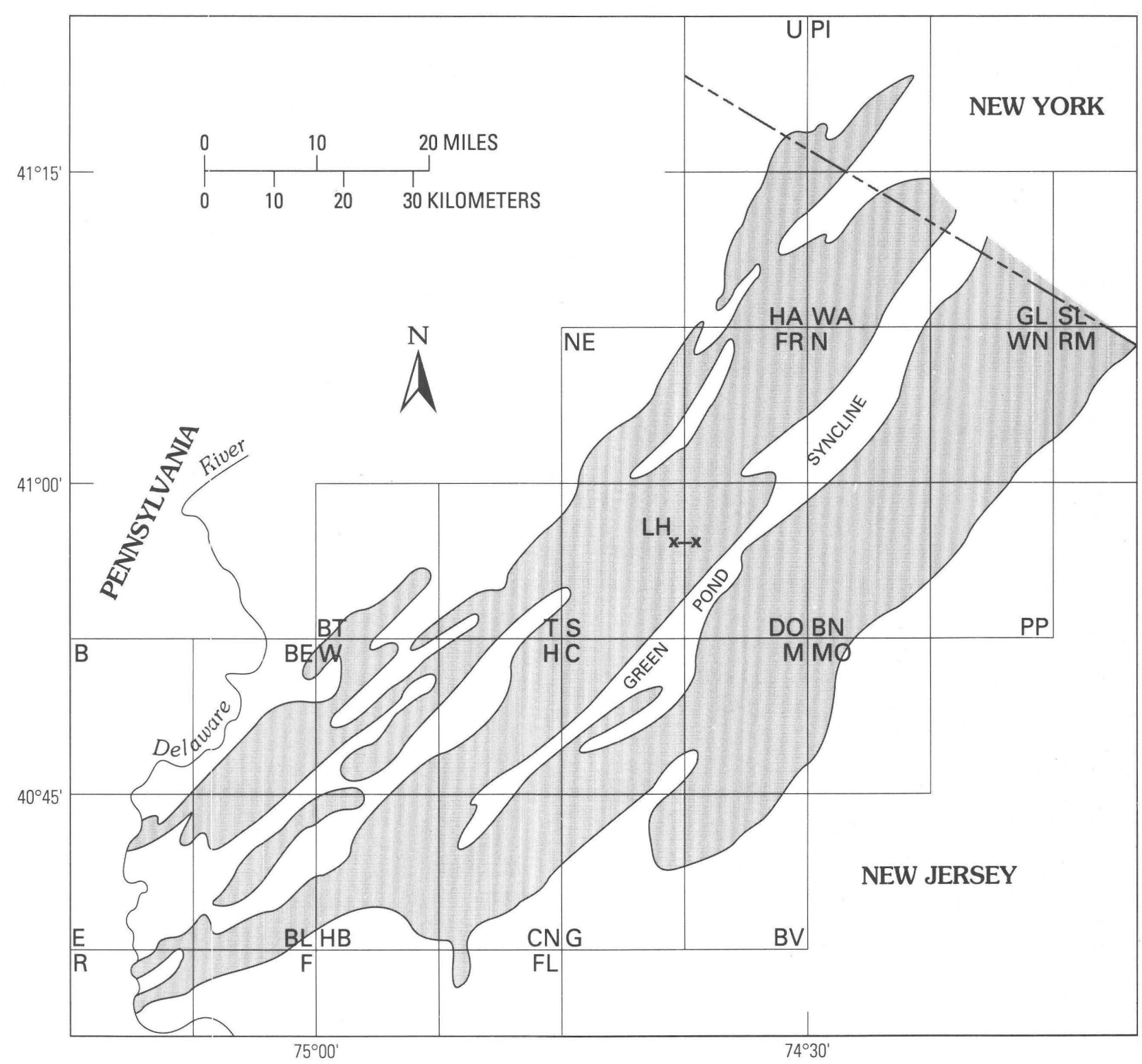

Figure A2. Distribution of Middle Proterozoic rocks of the Reading Prong in New Jersey and immediately adjacent New York. Quadrangles (7.5-minute) are as follows: R, Riegelsville; F, Frenchtown; FL, Flemington; E, Easton; BL, Bloomsbury; HB, High Bridge; CN, Califon; G, Gladstone; BV, Bernardsville; B, Banger; BE, Belvidere; W, Washington; H, Hackettstown; C, Chester; M, Mendham; MO, Morristown; BT, Blairstown; T, Tranquility; S, Stanhope; DO, Dover; BN, Boonton; PP, Pompton Plains; NE, Newton East; FR, Franklin; N, Newfoundland; WN, Wanaque; RM, Ramsey; HA, Hamburg; WA, Wawayanda; GL, Greenwood Lake; SL, Sloatsburg; U, Unionville; and PI, Pine Island. Place mentioned in text: LH, Lake Hopatcong area. The complexities of the Byram and Lake Hopatcong Intrusive Suites prevent them from being shown on a map at this scale.

Reading Prong in Pennsylvania at least to the Hudson River in New York, a distance of about $121 \mathrm{mi}$ (miles). Six new analyses of Byram rocks are presented in table A1. Chemically, the Byram rocks are granite or quartz monzonite (fig. A3). Drake (1984) pointed out that the chemistry of some of the Byram rocks in New Jersey suggests that they are hybrids. The samples plotting as trondhjemite, tonalite, and off the diagram (fig. A3) are also probably hybrids.
Rocks of the Byram Intrusive Suite are much more abundant in the southwestern part of the Reading Prong than in the eastern part of New Jersey and adjacent New York. The Byram has an upper intercept $\mathrm{Pb}-\mathrm{U}$ age of about 1090 Ma (Drake and others, chap. D, this vol.). The Byram is thought to have resulted from anatectic melting at a depth greater than the present erosion surface, because there is no evidence of melt generation in outcrop. 
Table A1. Chemical analyses and CIPW norms of rocks ${ }^{1}$ of the Byram Intrusive Suite

[In weight percent. Dashes indicate not present]

\begin{tabular}{|c|c|c|c|c|c|c|}
\hline & 1 & 2 & 3 & 4 & 5 & 6 \\
\hline \multicolumn{7}{|c|}{ Chemical analyses } \\
\hline $\mathrm{SiO}_{2}$ & 67.6 & 77.5 & 66.3 & 71.2 & 64.6 & 68.6 \\
\hline $\mathrm{Al}_{2} \mathrm{O}_{3}$ & 13.4 & 10.0 & 17.0 & 13.9 & 12.7 & 14.0 \\
\hline $\mathrm{Fe}_{2} \mathrm{O}_{3}$ & 3.4 & 1.0 & 1.5 & 1.1 & 3.9 & 3.81 \\
\hline $\mathrm{FeO}$ & 2.7 & 1.8 & 2.6 & 2.6 & 5.9 & 2.0 \\
\hline $\mathrm{MgO}$ & .56 & 1.0 & .66 & .34 & .19 & .32 \\
\hline $\mathrm{CaO}$ & 2.0 & 1.5 & 2.3 & 1.8 & 2.3 & .8 \\
\hline $\mathrm{Na}_{2} \mathrm{O}$ & 3.0 & .82 & 5.8 & 2.9 & 3.5 & 3.75 \\
\hline $\mathrm{K}_{2} \mathrm{O}$ & 4.4 & 4.5 & 1.8 & 5.6 & 4.2 & 5.31 \\
\hline $\mathrm{H}_{2} \mathrm{O}^{+}$ & .32 & .98 & .66 & .52 & .48 & .63 \\
\hline $\mathrm{H}_{2} \mathrm{O}^{-}$ & .2 & .32 & .3 & .07 & .07 & .06 \\
\hline $\mathrm{TiO}_{2}$ & .87 & .46 & 1.0 & .45 & .62 & .5 \\
\hline $\mathrm{P}_{2} \mathrm{O}_{5}$ & .15 & .1 & .2 & .11 & .09 & .09 \\
\hline $\mathrm{MnO}$ & .06 & .04 & .05 & .05 & .35 & .05 \\
\hline $\mathrm{CO}_{2}$ & .03 & .04 & .08 & .04 & .05 & .03 \\
\hline Total & 98.69 & 100.06 & 100.25 & 100.68 & 98.95 & 99.95 \\
\hline \multicolumn{7}{|c|}{ CIPW norms } \\
\hline Quartz & 29.6 & 51.2 & 19.7 & 27.4 & 21.2 & 24.8 \\
\hline Orthoclase & 26.7 & 27.2 & 10.6 & 33.4 & 25.6 & 31.7 \\
\hline Albite & 26.2 & 7.3 & 49.2 & 24.6 & 30.4 & 32.0 \\
\hline Anorthite & 9.2 & 6.7 & 10.6 & 8.1 & 6.1 & 3.1 \\
\hline Corundum & .2 & 1.2 & 1.7 & - & - & .9 \\
\hline Diopside & 1.6 & 4.2 & 3.6 & 1.9 & 3.9 & .8 \\
\hline Hypersthene & .7 & - & - & 2.0 & 5.4 & - \\
\hline Magnetite & 5.1 & 1.4 & 2.1 & 1.6 & 5.8 & 5.3 \\
\hline Ilmenite & 1.7 & .9 & 2.0 & .9 & 1.2 & .9 \\
\hline Apatite & .3 & .3 & .3 & .3 & .3 & .3 \\
\hline Hematite & - & - & - & - & - & .2 \\
\hline Total & 101.3 & 100.4 & 99.8 & 100.2 & 99.9 & 100.0 \\
\hline
\end{tabular}

${ }^{1}$ Descriptions and locations of rocks are as follows:

1. Hornblende granite from outcrops on east side of northbound lanes of N.J. Route 15 about 0.2 mile south of Tierney's Corner, Dover 7.5-minute quadrangle, N.J. Chemically, the rock is quartz monzonite. Rapid rock analysis by L. Mei, U.S. Geological Survey.

2. Hornblende granite from outcrops on southbound lane of N.J. Route 15 about 0.35 mile south of intersection with Sparta Road, Newton East 7.5-minute quadrangle, N.J. The rock has a "messy" appearance, contains abundant fluorite, and does not plot in a named field on the O'Connor (1965) normative feldspar plot. Same analyst as 1.

3. Hornblende granite from outcrops along west bank of Ravine Lake at the dam abutment, Gladstone 7.5-minute quadrangle, N.J. Chemically, the rock is trondhjemite. Same analyst as 1 .

4. Hornblende granite from outcrops on ridge nose along unnumbered road about 0.85 mile southwest of the village of Echo Lake, Newfoundland 7.5-minute quadrangle, N.J. Chemically, the rock is quartz monzonite. Rapid rock analysis by H. Smith, U.S. Geological Survey.

5. Hornblende granite from outcrops along unnumbered road about 0.55 airline mile N. $25^{\circ} \mathrm{W}$. from Seneca Lake, Newton East 7.5-minute quadrangle, N.J. Chemically, the rock is granite. Same analyst as 4 .

6. Magnetite alaskite from outcrops along unnumbered road about 1.3 airline miles from Califon, Califon 7.5-minute quadrangle, N.J. Chemically, the rock is granite. Rapid rock analysis by J. Taggart, A. Bartel, and D. Siems, U.S. Geological Survey.

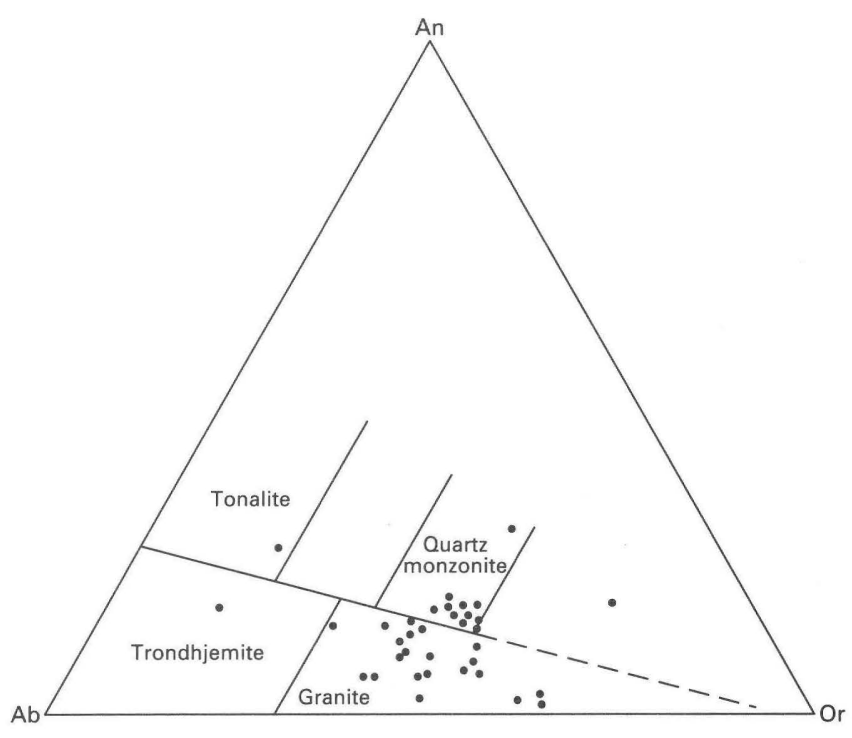

Figure A3. Normative feldspar plot (O'Connor, 1965) of rocks of the Byram Intrusive Suite. Data from Drake (1984) and this study.

\section{LAKE HOPATCONG INTRUSIVE SUITE}

Rocks of the clinopyroxene-bearing, quartz-poor Lake Hopatcong Intrusive Suite (here named) are characterized by mesoperthite or microantiperthite and were first mapped as such by Baker and Buddington (1970). Such rocks were recognized, however, by Hague and others (1956), who called them Type III Byram gneiss. In addition, Sims (1958) recognized a sheet of pyroxene granite in the Boonton quadrangle (fig. A2), but included it in his hornblende granite. Young $(1971,1972,1978)$ has made special studies of these rocks.

Rocks of the Lake Hopatcong Intrusive Suite are most abundant in the Stanhope, Franklin, Dover, and Wawayanda quadrangles (fig. A2). At one time it was thought they did not occur south of the Green Pond syncline (fig. A2). However, our work shows that they occur throughout the New Jersey Highlands, in the High Bridge, Califon, Hackettstown, Chester, Tranquility, Mendham, Pompton Plains, and Newfoundland quadrangles, pyroxene granite being much more abundant than quartz-poor varieties away from the Lake Hopatcong area. Lake Hopatcong rocks have not been recognized in the Hudson Highlands, although Dodd (1965) reported that two specimens of Storm King Granite from Bear Mountain, N.Y., contain less than 1 percent clinopyroxene, but contain neither mesoperthite nor microantiperthite. Neither pyroxene granite nor pyroxene syenite have been recognized in Pennsylvania.

Rocks of the Lake Hopatcong Intrusive Suite are medium to medium coarse grained, buff to greenish gray, and gneissoid to indistinctly foliated. They are composed largely of mesoperthite or microantiperthite, quartz, oligoclase, and clinopyroxene (ferrohedenbergite). The rocks 


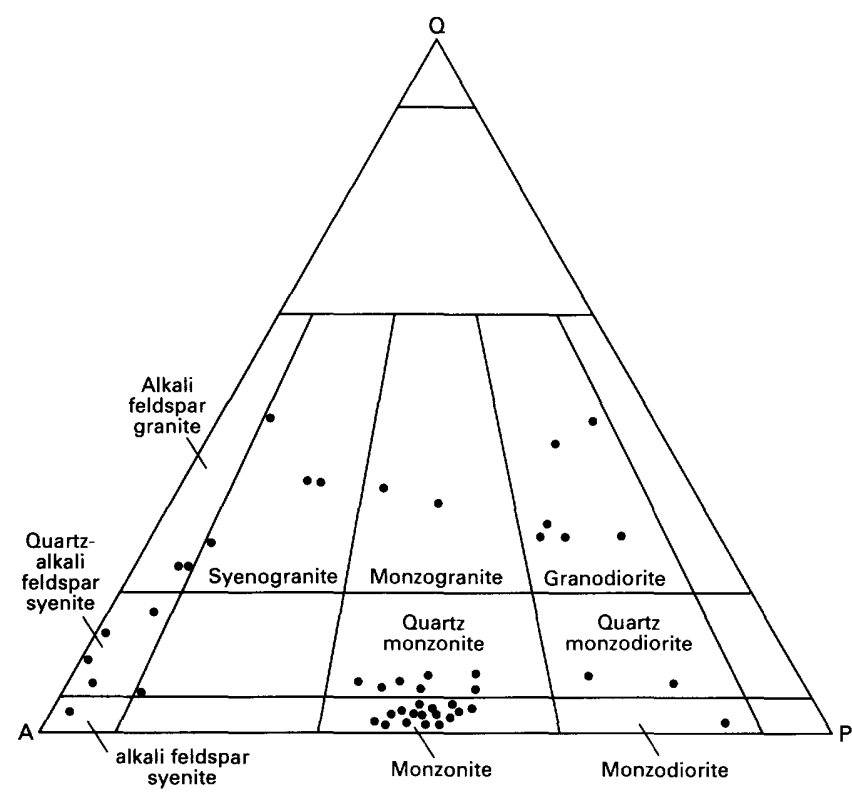

Figure A4. Quartz-alkali feldspar-plagioclase plot (Streckeisen, 1976) of rocks of the Lake Hopatcong Intrusive Suite. Data from Baker and Buddington (1970), Drake (1984, unpub.), Hague and others (1956), and Young (1971, 1972, 1978).

invariably contain titanite and trace amounts of sulfide. Petrographically, the quartz-poor rocks range from quartz monzodiorite to quartz-alkali feldspar syenite and alkali feldspar syenite (fig. A4). The granites range from granodiorite to alkali feldspar granite (fig. A4). Abundant chemical and modal data have been presented by Baker and Buddington (1970), Drake (1984), and Young (1978). Additional chemical data are given in table A2. Chemically, the rocks are trondhjemite and granite (fig. A5), the bulk of

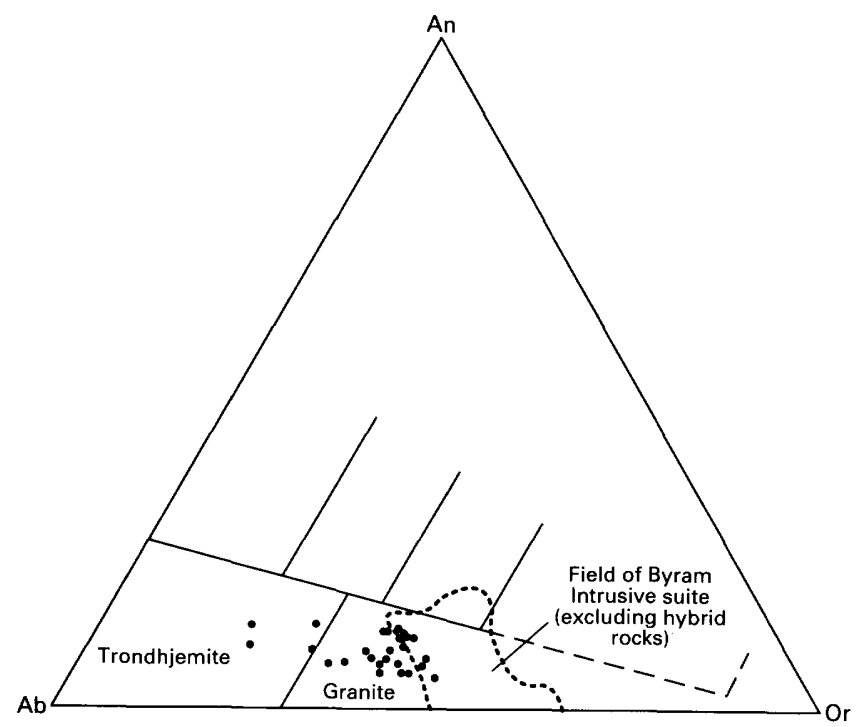

Figure A5. Normative feldspar plot (O'Connor, 1965) of rocks of the Lake Hopatcong Intrusive Suite. Data from Drake (1984), Young (1978), and this study.
Table A2. Chemical analyses and CIPW norms of rocks ${ }^{1}$ of the Lake Hopatcong Intrusive Suite

[In weight percent. Dashes indicate not present.]

\begin{tabular}{|c|c|c|c|c|c|c|c|}
\hline & 1 & 2 & 3 & 4 & 5 & 6 & 7 \\
\hline \multicolumn{8}{|c|}{ Chemical analyses } \\
\hline $\mathrm{SiO}_{2}$ & 64.5 & 74.4 & 68.6 & 73.5 & 68.9 & 65.5 & 61.3 \\
\hline $\mathrm{Al}_{2} \mathrm{O}_{3}$ & 17.8 & 12.6 & 14.0 & 12.2 & 14.1 & 14.3 & 16.1 \\
\hline $\mathrm{Fe}_{2} \mathrm{O}_{3}$ & 1.1 & 1.82 & 3.81 & 4.1 & 3.49 & 4.22 & 5.1 \\
\hline $\mathrm{FeO}$ & 1.4 & 1.0 & 2.0 & 1.3 & 1.3 & 2.6 & 3.1 \\
\hline $\mathrm{MgO}$ & 1.4 & .24 & .32 & .24 & .26 & .49 & .77 \\
\hline $\mathrm{CaO}$ & 2.5 & .89 & .80 & 1.69 & 1.27 & 2.4 & 2.4 \\
\hline $\mathrm{Na}_{2} \mathrm{O}$ & 7.1 & 4.42 & 3.75 & 4.58 & 4.65 & 4.65 & 5.74 \\
\hline $\mathrm{K}_{2} \mathrm{O}$ & 3.0 & 3.79 & 5.31 & 2.01 & 4.9 & 4.83 & 4.37 \\
\hline $\mathrm{H}_{2} \mathrm{O}^{+}$ & .65 & .15 & 160 & $\{08$ & $\{16$ & $\{08$ & $\{07$ \\
\hline $\mathrm{H}_{2} \mathrm{O}^{-}$ & .21 & .08 & $\{.69$ & $\{.08$ & $\{.16$ & $\{.08$ & $\{.0\}$ \\
\hline $\mathrm{TiO}_{2}$ & .42 & .29 & .50 & .40 & .37 & .60 & .99 \\
\hline $\mathrm{P}_{2} \mathrm{O}_{5}$ & .13 & .05 & .09 & .06 & .06 & .11 & .18 \\
\hline $\mathrm{MnO}$ & .04 & .02 & .05 & .04 & .06 & .08 & .13 \\
\hline $\mathrm{CO}_{2}$ & .02 & .02 & .03 & - & - & - & 一 \\
\hline Total & 100.27 & 99.77 & 99.95 & 100.2 & 99.52 & 99.86 & 100.25 \\
\hline \multicolumn{8}{|c|}{ CIPW norms } \\
\hline Quartz & 5.3 & 32.5 & 24.9 & 35.7 & 21.0 & 17.3 & 7.3 \\
\hline Orthoclase & 17.8 & 22.2 & 31.7 & 11.7 & 28.9 & 28.4 & 26.1 \\
\hline Albite & 60.3 & 37.7 & 32.0 & 38.8 & 39.8 & 39.3 & 48.7 \\
\hline Anorthite & 7.8 & 3.6 & 3.1 & 7.0 & 3.1 & 3.9 & 5.0 \\
\hline Corundum & - & - & .9 & - & - & - & 一 \\
\hline Wollastonite & - & - & - & - & .4 & 1.3 & .4 \\
\hline Diopside & 3.1 & .6 & .8 & .4 & 1.3 & 3.3 & 4.1 \\
\hline Hypersthene & 3.0 & - & - & .4 & - & - & - \\
\hline Magnetite & 1.6 & 2.3 & 5.3 & 3.0 & 3.2 & 6.0 & 7.4 \\
\hline Ilmenite & .8 & .6 & .9 & .8 & .8 & 1.2 & 2.1 \\
\hline Apatite & .3 & .3 & .3 & .3 & .3 & .3 & .3 \\
\hline Hematite & - & .2 & .2 & 2.1 & 1.3 & - & - \\
\hline Total & 100.0 & 100.0 & 100.1 & 100.2 & 100.1 & 101.0 & $\overline{101.4}$ \\
\hline
\end{tabular}

${ }^{1}$ Descriptions and locations of rocks are as follows:

1. Pyroxene granite from outcrops along Peapack Brook about 1 mile north-northwest of St. Bernardo School, Gladstone 7.5-minute quadrangle, N.J. Chemically, the rock is trondhjemite. Rapid rock analysis by L. Mei, U.S. Geological Survey.

2. Pyroxene granite from outcrops on east side of north-trending road 200 feet north of intersection with east-trending road 1,000 feet west of Fayson Lakes Village, Pompton Plains 7.5-minute quadrangle, N.J. Chemically, the rock is granite. Rapid rock analysis by J. Taggart, A. Bartel, and D. Siems, U.S. Geological Survey.

3. Pyroxene alaskite from outcrops on east side of northwesttrending road 1,100 feet northwest of intersection with northeast-trending road about 1.3 miles west of Lower Valley, Califon 7.5-minute quadrangle, N.J. Chemically, the rock is granite. X-ray fluorescence analysis by Nuclear Activation Services, Inc., Ann Arbor, Mich.

4. Pyroxene granite from outcrop on west side of road 0.45 mile north of road intersection 600 feet west of Hudson Maxim School, Hopatcong, Stanhope 7.5-minute quadrangle, N.J. Chemically, the rock is trondhjemite. Same analyst as 3 .

5. Pyroxene granite from outcrop at second right-angle bend in unimproved road 1,000 feet north of northern limit of Hopatcong Hills, Stanhope 7.5-minute quadrangle, N.J. Chemically, the rock is granite. Same analyst as 3 .

6. Pyroxene-quartz syenite from outcrop at road intersection 1,750 feet northwest of Byram Cove, Stanhope 7.5-minute quadrangle, N.J. Chemically, the rock is syenite. Same analyst as 3 .

7. Pyroxene syenite from outcrop along west-bound lane of Interstate 80900 feet east of Route 206 interchange. Chemically, the rock is syenite. Same analyst as 3 . 


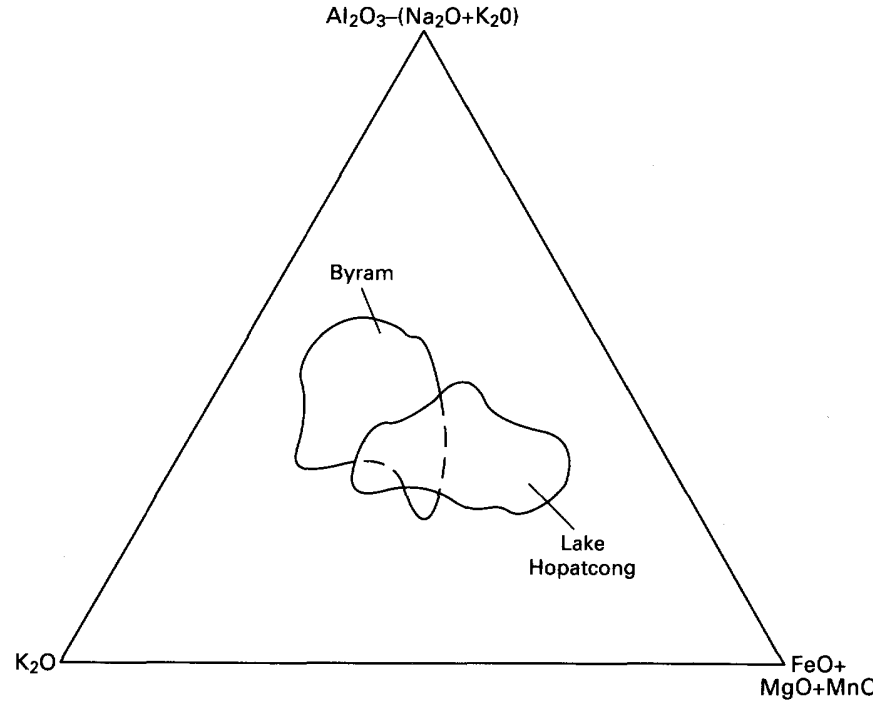

A

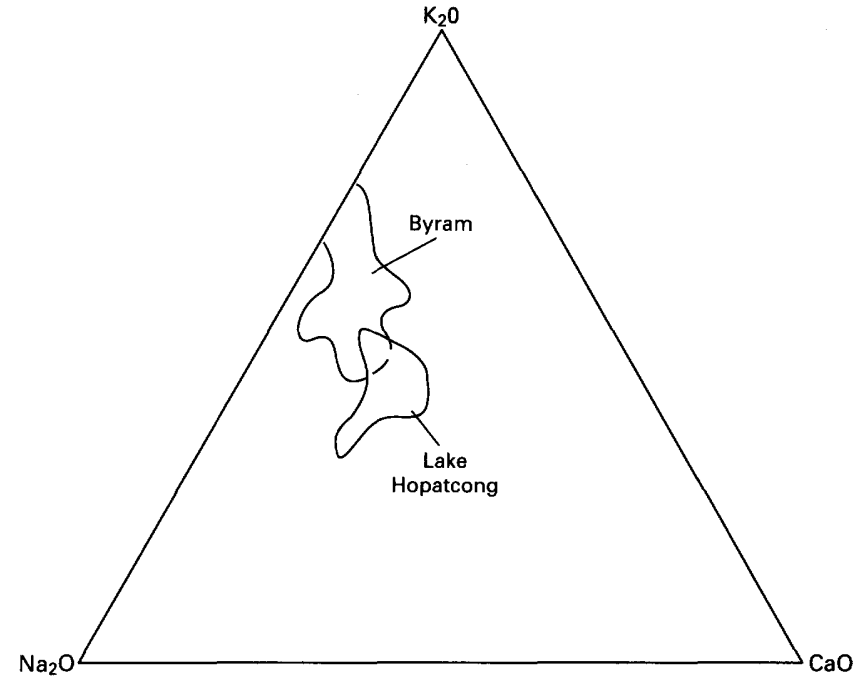

B

Figure A6. Plots comparing the bulk chemistry of the Lake Hopatcong (35 analyses) and Byram (40 analyses) Intrusive Suites. Data from Baker and Buddington (1970), Drake (1969, 1984, this study), and Young (1978). A, Modified A-K-F plot; $B, \mathrm{Na}_{2} \mathrm{O}-\mathrm{K}_{2} \mathrm{O}-\mathrm{CaO}$ plot.

the granites being more sodic than those of the Byram. Granitic and quartz-poor phases commonly are found in the same outcrop, and map units are defined by the major phase present. This being the case, neither granite nor syenite is formally named.

The relation of the Lake Hopatcong Intrusive Suite to the Byram Intrusive Suite is a major problem in New Jersey Highlands geology. Baker and Buddington (1970) suggested that the pyroxene-bearing rocks resulted from the desilication of Byram magma. This would not appear to be the case, as there is as much, if not more, amphibolite associated with mapped rocks of the Byram that are not desilicated. Drake (1984) presented chemical data for microperthite alaskite and amphibolite from the same outcrop, the alaskite containing a normal amount of quartz. In fact, Buckwalter $(1959,1962)$ and Drake $(1969,1984)$ suggested that some of the Byram hornblende granite is amphibolite granitized by alaskitic fluids.


A

B

Figure A7. Plots comparing normative mineralogy of rocks of the Lake Hopatcong (35 analyses) and Byram (40 analyses) Intrusive Suites. Data from Baker and Buddington (1970), Drake (1969, 1984, this study), and Young (1978). $A$, Q-Ab-Or plot; $B, \mathrm{Q}-\mathrm{Or}-\mathrm{Ab}+$ An plot. 
Table A3. Fe-Mg ratios of some rocks of the Lake Hopatcong and Byram Intrusive Suites,

[Data from Baker and Buddington (1970), Drake (1984), and this study]

\begin{tabular}{rr}
\hline Lake Hopatcong & Byram \\
\hline 38.0 & 18.3 \\
26.2 & 16.7 \\
23.1 & 15.2 \\
22.6 & 12.9 \\
22.5 & 10.0 \\
22.1 & 9.3 \\
22.0 & 7.5 \\
21.1 & 6.2 \\
18.4 & 6.0 \\
18.3 & 5.5 \\
18.2 & 4.1 \\
15.5 & 3.9 \\
13.9 & 3.7 \\
11.8 & 3.5 \\
10.5 & 2.8 \\
9.0 & 2.6 \\
8.3 & 2.3 \\
8.2 & 2.2 \\
1.8 & 2.1 \\
18.3 & Median 5.5 \\
Mean 17.4 & Mean 7.1 \\
\hline &
\end{tabular}

Rhett (1975) suggested that all the granite in the New Jersey Highlands originally contained pyroxene and that retrograde reactions south of the Green Pond syncline (fig. A2) altered the pyroxene to hornblende and quartz. This would not appear to be the case, as there is abundant hornblende granite north of the Green Pond syncline as well as east and west of the Lake Hopatcong area. In addition, the rocks south of the Green Pond syncline appear to be at higher metamorphic grade than those to the north (Offield, 1967; Drake, 1984).

The Lake Hopatcong and Byram Intrusive Suites differ in chemistry (fig. A6, table A3), normative mineralogy (fig. A7), and petrography. They clearly are two entities, but their petrogenetic relations await the completion of more sophisticated chemical studies.

\section{REGIONAL RELATIONS}

The similarity between the rocks of the Reading Prong and those of the Adirondacks has been recognized for many years (Engel, 1956; Sims, 1958; Drake, 1969, 1984; Baker and Buddington, 1970). Chemically, the hornblende granites and alaskites of the Adirondacks (fig. A8) are similar to many rocks of the Byram Intrusive Suite (fig. A3), although the Byram rocks have a much more variable composition. The two suites are also similar on an AFM plot (fig. A9), although the Byram rocks occupy a more extensive field. Rocks of the Lake Hopatcong Intrusive

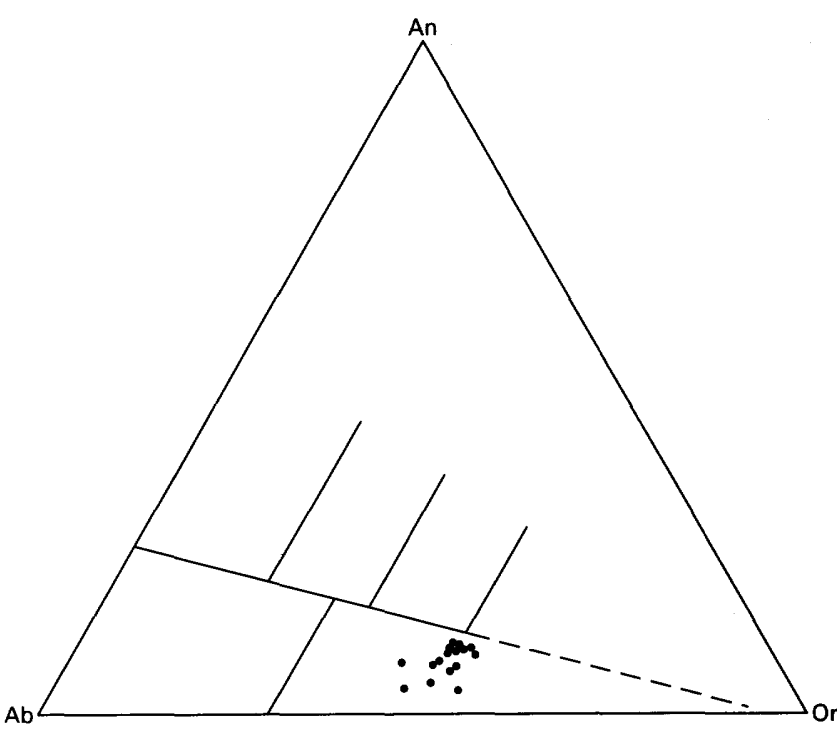

Figure A8. Normative feldspar plot $\left(\mathrm{O}^{\prime}\right.$ Connor, 1965) of hornblende granite and alaskite from the Adirondack massif. All rocks are granite. Data from Buddington (1939, 1957) and Buddington and Leonard (1962).

Suite have some similarities to the quartz syenites of the Adirondacks (fig. A10), although the Adirondack rocks typically contain more normative anorthite and lack the range of composition of the Lake Hopatcong rocks.

Rankin, Drake, and Ratcliffe (in press) have categorized the igneous rocks of the Reading Prong, Berkshire massif, and Green Mountain massif as defining prekine-

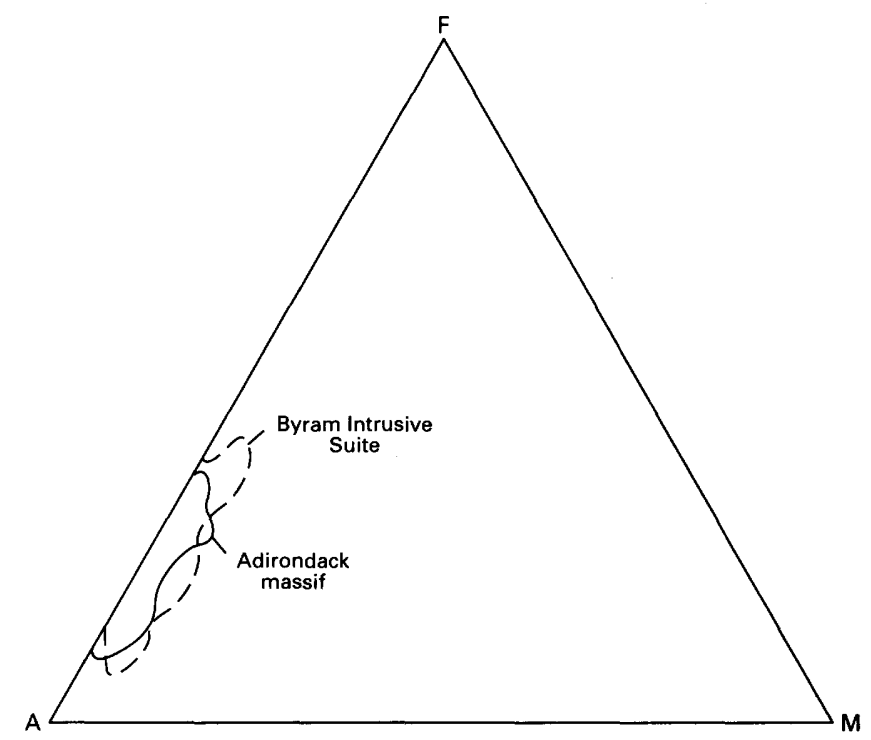

Figure A9. AFM plot comparing rocks of the Byram Intrusive Suite with hornblende granite and alaskite from the Adirondack massif. Data from Buddington (1939, 1957), Buddington and Leonard (1962), Drake (1984), and this study. 


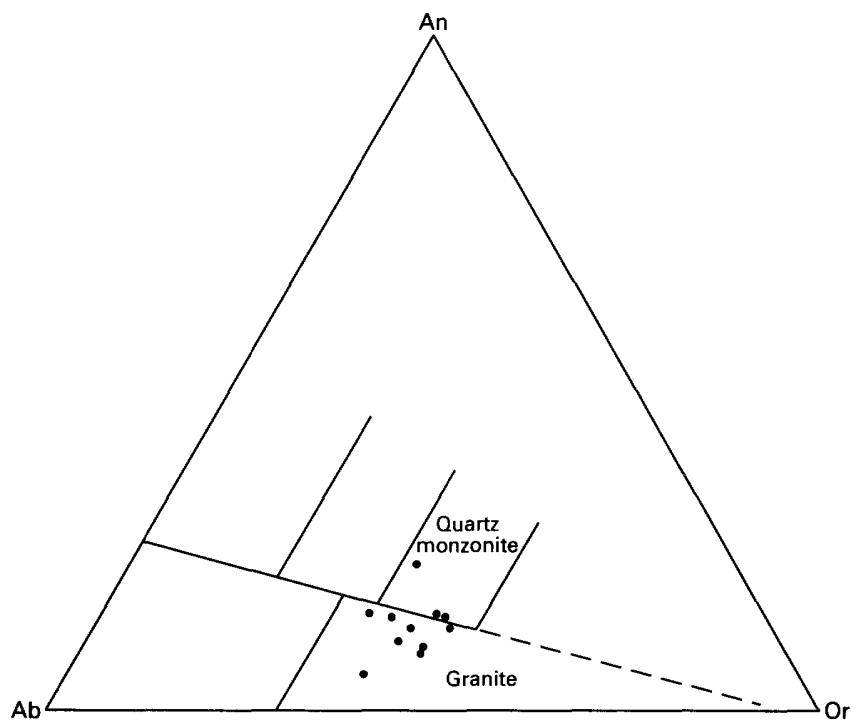

Figure A10. Normative feldspar plot of quartz syenites from the Adirondack massif. Data from Buddington (1939, 1957) and Buddington and Leonard (1962).

matic, synkinematic, and postkinematic sequences. The rocks of the Byram Intrusive Suite are similar chemically to the synkinematic rocks of both the Berkshire and Green Mountain massifs. No pyroxene-bearing granites or syenites, however, are known in those massifs. It would appear, then, that the Reading Prong is more similar to the Adirondacks than to the Berkshire and Green Mountain massifs. Interestingly, the prekinematic and postkinematic sequences in the Reading Prong, Berkshire massif, and Green Mountain massif are also similar (Rankin and others, in press). An understanding of the Middle Proterozoic geology of the Appalachian orogen is beginning to emerge.

\section{REFERENCES CITED}

Baker, D.R., and Buddington, A.F., 1970, Geology and magnetite deposits of the Franklin quadrangle and part of the Hamburg quadrangle, New Jersey: U.S. Geological Survey Professional Paper 638, 73 p.

Bayley, W.S., 1941, Pre-Cambrian geology and mineral resources of the Delaware Water Gap and Easton quadrangles, New Jersey and Pennsylvania: U.S. Geological Survey Bulletin 920, 96 p.

Buckwalter, T.V., 1959, Geology of the Precambrian rocks and Hardyston Formation of the Boyertown quadrangle: Pennsylvania Geological Survey, 4th ser., Geological Atlas 197, $15 \mathrm{p}$.

1962, The Precambrian geology of the Reading 15-minute quadrangle: Pennsylvania Geological Survey, 4th ser., Progress Report 161, 49 p.

Buddington, A.F., 1939, Adirondack igneous rocks and their metamorphism: Geological Society of America Memoir 7, $354 \mathrm{p}$.
1957, Interrelated Precambrian granitic rocks, northwest Adirondacks, New Y $\mathbf{k}$ : Geological Society of America Bulletin, v. 68, p. 291-306.

Buddington, A.F., and Leonard, B.F., 1962, Regional geology of the St. Lawrence County magnetite district, northwest Adirondacks, New York: U.S. Geological Survey Professional Paper 376, 145 p.

Dodd, R.T., Jr., 1965, Precambrian geology of the Popolopen Lake quadrangle, southeastern New York: New York State Museum and Science Service Map and Chart Series 6, 39 p.

Drake, A.A., Jr., 1969, Precambrian and Lower Paleozoic geology of the Delaware Valley, New Jersey-Pennsylvania, in Subitzky, Seymour, ed., Geology of selected areas in New Jersey and eastern Pennsylvania and Guidebook of excursions: New Brunswick, N.J., Rutgers University Press, p. 51-131.

1984, The Reading Prong of New Jersey and eastern Pennsylvania: An appraisal of rock relations and chemistry of a major Proterozoic terrane in the Appalachians, in Bartholomew, M.J., ed., The Grenville event in the Appalachians and related topics: Geological Society of America Special Paper 194, p. 75-109.

Drake, A.A., Jr., Hall, L.M., and Nelson, A.E., 1988, Basement and basement-cover relation map of the Appalachian orogen in the United States: U.S. Geological Survey Miscellaneous Investigations Map I-1655, scale 1:1,000,000.

Engel, A.E.J., 1956, Apropos the Grenville, in Thompson, J.E., The Grenville problem: Royal Society Canada Special Publication 1, p. 74-98.

Hague, J.M., Baum, J.L., Herrman, L.A., and Pickering, R.J., 1956, Geology and structure of the Franklin-Sterling area, New Jersey: Geological Society of America Bulletin, v. 67, p. 434-474.

Hotz, P.E., 1953, Magnetite deposits of the Sterling Lake, New York-Ringwood, New Jersey, area: U.S. Geological Survey Bulletin 982-F, p. 153-244.

O'Connor, J.T., 1965, A classification for quartz-rich igneous rocks based on feldspar ratios: U.S. Geological Survey Professional Paper 525-B, p. B79-B84.

Offield, T.W., 1967, Bedrock geology of the Goshen-Greenwood Lake area, New York: New York State Museum and Science Service Map and Chart Series 9, 78 p.

Rankin, D.W., Drake, A.A., Jr., and Ratcliffe, N.M., in press, Proterozoic North American (Laurentian) rocks of the Appalachian orogen, in Reed, J.C., Jr., Bickford, M.E., Houston, R.S., Link, P.K., Rankin, D.W., Sims, P.K., and Van Schmus, W.R., Precambrian: Conterminous U.S. (The Geology of North America, v. C-2): Boulder, Colo., Geological Society of America.

Rankin, D.W., Hall, L.M., Drake, A.A., Jr., Goldsmith, Richard, Ratcliffe, N.M., and Stanley, R.S., 1989, Proterozoic evolution of the rifted margin, in Hatcher, R.D., Jr., Thomas, W.A., and Viele, G.W., eds., The Appalachian and Ouachita regions (The Geology of North America, v. F-2): Boulder, Colo., Geological Society of America, p. 101-177.

Rhett, D.W., 1975, Phase relationships and petrogenetic environment of Precambrian granites: Unpub. Ph.D. dissertation, Rutgers University (New Brunswick, N.J.), 157 p. 
Sims, P.K., 1958, Geology and magnetite deposits of the Dover district, Morris County, New Jersey: U.S. Geological Survey Professional Paper 287, 162 p.

Spencer, A.C., Kummel, H.B., Wolff, J.E., Salisbury, R.D., and Palache, Charles, 1908, Franklin Furnace, New Jersey: U.S. Geological Survey Geologic Atlas of the United States, Folio 161, 27 p.

Streckeisen, Albert, 1976, To each plutonic rock its proper name: Earth Science Reviews, v. 12, p. 1-33.
Young, D.A., 1971, Precambrian rocks of the Lake Hopatcong area, New Jersey: Geological Society of America Bulletin, v. 82, p. 143-158.

1972, A quartz syenite intrusion in the New Jersey Highlands: Journal of Petrology, v. 13, p. 511-528.

1978, Precambrian salic intrusive rocks of the Reading Prong: Geological Society of America Bulletin, v. 89, p. 1502-1514. 
Chapter B

\section{The High Point Member (Upper Ordovician) of the Martinsburg Formation in Northern New Jersey and Southeastern New York}

By AVERY ALA DRAKE, JR.

Prepared in cooperation with the

New Jersey Geological Survey

U.S. GEOLOGICAL SURVEY BULLETIN 1952

CONTRIBUTIONS TO NEW JERSEY GEOLOGY 


\title{
CONTENTS
}

\author{
Abstract B1 \\ Introduction B1 \\ Bushkill Member B1 \\ Ramseyburg Member B2 \\ Pen Argyl Member B4 \\ High Point Member B4 \\ Regional Relations $\quad$ B7 \\ References Cited B9
}

\section{FIGURES}

B1. Generalized geologic map of parts of northern New Jersey and southeastern New York B2

B2. Simplified geologic map of the High Point Member of the Martinsburg Formation B3

B3. Schematic diagram showing the relation of the members of the Martinsburg Formation B4

B4. Ideal sequence (the Bouma sequence) of structures in a turbidite bed B4 B5-B10. Photographs showing:

B5. Typical exposure of Ramseyburg Member of the Martinsburg Formation B6

B6. Abundant load casts on the bottom of a Ramseyburg graywacke bed $\mathbf{B} 7$

B7. Scoured shale remnants on the top of a High Point graywacke bed $\mathbf{B} 7$

B8. Rip-up clasts of shale in High Point graywacke B7

B9. Outcrop of typical High Point $\mathbf{B 8}$

B10. Very large load casts in the High Point $\mathbf{B 8}$

TABLE

B1. Classification of turbidite and other resedimented facies

B5 


\title{
The High Point Member (Upper Ordovician) of the Martinsburg Formation in Northern New Jersey and Southeastern New York
}

\author{
By Avery Ala Drake, Jr.
}

\begin{abstract}
The High Point Member of the Martinsburg Formation is a unit of thick-bedded graywacke, amalgamated graywacke, and much less abundant dark-colored shale in northernmost New Jersey and southeastern New York. It occurs stratigraphically above the Ramseyburg Member, as does the Pen Argyl Member in the Delaware Valley. Although probably of about the same age, these units are radically different sedimentologically. The muddy turbidites of the Pen Argyl were deposited in a densitystratified, anoxic basin, whereas the High Point is a sequence of high-energy turbidite facies $B$ and less abundant facies $C$ deposits. The High Point is a much more proximal deposit than the rocks of the Martinsburg to the southwest, and its character supports the concept based on paleocurrent information that the Martinsburg foreland basin was filled longitudinally from the northeast.
\end{abstract}

\section{INTRODUCTION}

The Martinsburg Formation is the fill in the Martinsburg foreland basin in the central Appalachians (Drake and others, 1989). In the Delaware Valley of New Jersey and Pennsylvania, the Martinsburg consists of three members, a lower Bushkill, a middle Ramseyburg, and an upper Pen Argyl, aggregating to a total thickness of about $14,000 \mathrm{ft}$ (feet) (Drake and Epstein, 1967). This is the greatest thickness known from Virginia to New York, suggesting that the foreland basin is deepest here. This great thickness probably results from downbuckling due to the thrust load of the Hamburg klippe (Lash and Drake, 1984), following the concept of Jordan (1981).

Geologic mapping at a scale of 1:24,000 (Drake and others, 1969, 1985; Drake and Lyttle, 1985; A.A. Drake, Jr., unpub. data) has traced the Bushkill and Ramseyburg Members into southeastern New York (fig. B1), and

Manuscript approved for publication July 19, 1990.
Epstein and Lyttle (1987) reported that the Bushkill Member can be recognized at least as far northeast as the Newburgh, N.Y., area. In southeastern New York, the Bushkill and Ramseyburg were miscorrelated with the Mount Merino Shale Member of the Normanskill Shale and Austin Glen Graywacke, units of the Taconic klippe, by Offield (1967). The Pen Argyl Member, on the other hand, disappears beneath the Silurian Shawangunk Formation just west of the Delaware River (Drake and Epstein, 1967).

In northernmost New Jersey, a unit of thick-bedded graywacke and much less dark shale appears above the Ramseyburg (figs. B1, B2). This unit is here named the High Point Member of the Martinsburg Formation, for typical exposures at High Point State Park and south along New Jersey Route 23 to Colesville, Port Jervis South quadrangle, Sussex County, N.J. (fig. B2).

The Bushkill, Ramseyburg, and Pen Argyl Members of the Martinsburg Formation are discussed briefly below to establish their relation to the High Point and to point up the changes in the foreland basin between the Delaware Valley and southeastern New York. The relation of these members is shown in figure B3.

\section{BUSHKILL MEMBER}

In the Delaware Valley, the Bushkill Member overlies the euxinic cement rock facies of the Jacksonburg Limestone, the contact being marked by a decrease in carbonate and an increase in pelitic material (Drake, 1969). The basal Bushkill is black to dark-gray slate, reflecting the continuing stagnant conditions of the foreland basin at this time. Within a short vertical distance, thin-bedded slate and siltstone appear. Few beds exceed 4 in (inches) in thickness, and most are less than half an inch thick. Silt-shale ratios range from about 1:3 to 1:6, the lithologic change forming "ribbons" on slaty cleavage surfaces. In terms of Bouma's (1962) turbidite model (fig. B4), most beds lack one or more of the basal units and can be classed as $\mathrm{T}_{\mathrm{b}-\mathrm{e}}, \mathrm{T}_{\mathrm{c}-\mathrm{e}}$, or $T_{d-e}$ turbidites. $T_{c-e}$ beds appear to be most common. These 


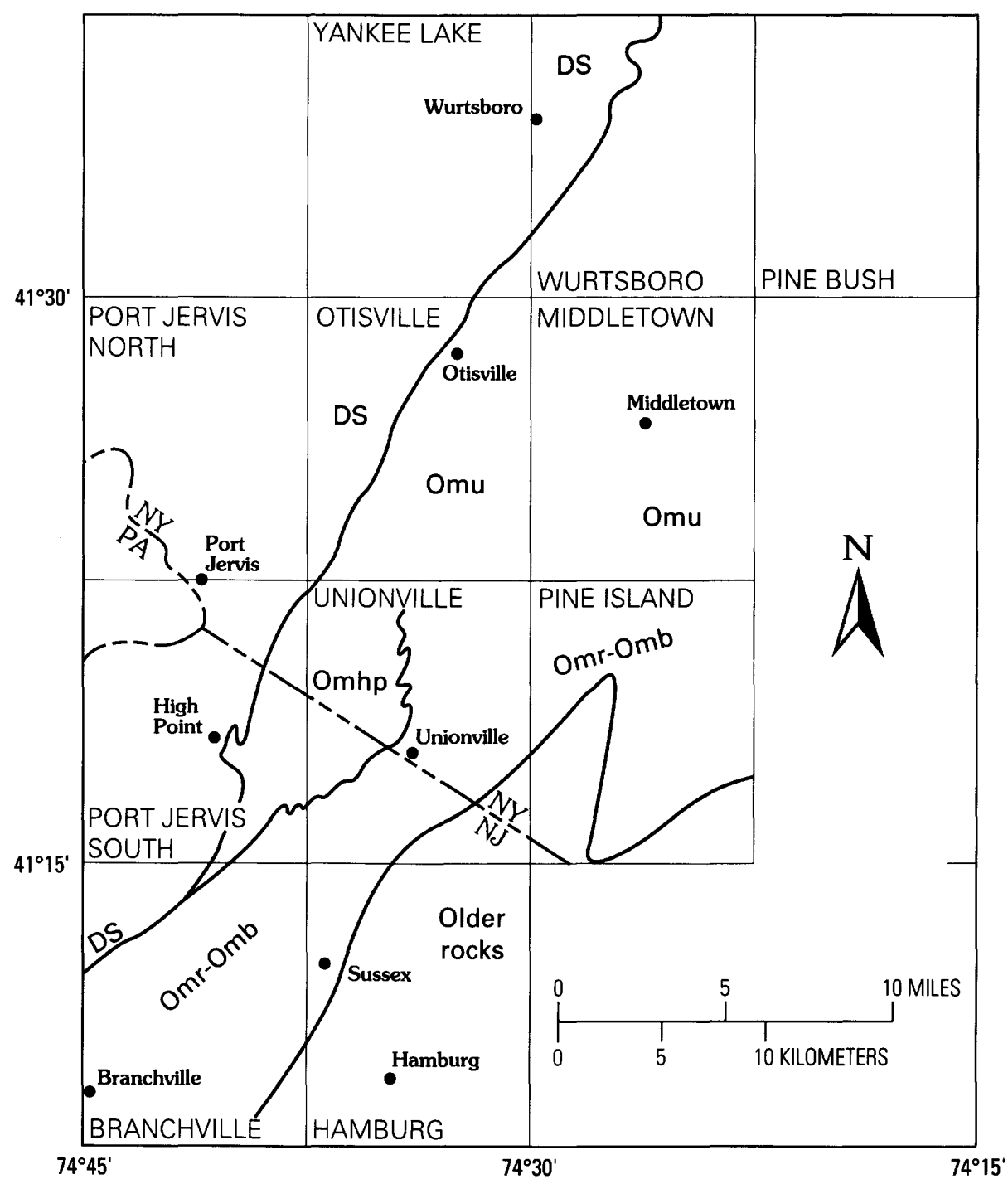

Figure B1. Generalized geologic map of parts of northern New Jersey and southeastern New York showing distribution of the Martinsburg Formation and location of 7.5-minute quadrangles. Rock units: DS, undivided Silurian and Devonian rocks; Omu, Martinsburg Formation undivided; Omhp, High Point Member of Martinsburg Formation; Omr-Omb, Bushkill and Ramseyburg Members of Martinsburg Formation undivided. Sources of data: New Jersey, detailed geologic mapping by A.A. Drake, Jr.; New York, Fisher and others (1970).

rocks are assigned to turbidite facies D of Mutti and Ricci Lucchi (1978) and Walker and Mutti (1973) (table B1). These rocks, then, are classic "distal" turbidites.

In the Delaware Valley, the Bushkill is about $4,000 \mathrm{ft}$ thick. To the northeast, in the Unionville quadrangle (fig. B1), it is about $1,500 \mathrm{ft}$ thick. The euxinic basal part of the unit thickens, and turbidites first appear higher in the Bushkill. The changes in thickness and facies are difficult to track because much of the Martinsburg is covered by klippen of carbonate rocks in north-central New Jersey (Drake and others, 1985; Drake and Lyttle, 1985; A.A. Drake, Jr., unpub. data).

The Bushkill is difficult to date precisely, as its contained graptolite fauna is sparse, represents a very restricted and extreme biofacies, and contains only a few species which are both hard to identify and long ranging. It is younger than the Jacksonburg Limestone, so its lower part is probably of Rocklandian to Kirkfieldian (Llandeilian) age, and on the basis of graptolites, the unit ranges from Kirkfieldian (Llandeilian) to Edenian (Caradocian) in age (Drake and others, 1989).

\section{RAMSEYBURG MEMBER}

The Bushkill grades up into the Ramseyburg Member, a sequence of alternating beds of slate and thin- to thick-bedded graywacke and graywacke siltstone (fig. B5). The graywacke beds range from less than an inch to as 




$15^{\prime}$

$74^{\circ} 37^{\prime} 30^{\prime \prime}$

Figure B2. Simplified geologic map of the High Point Member of the Martinsburg Formation in the Unionville quadrangle, New York-New Jersey, and the Port Jervis South quadrangle, New Jersey-New York. Ss, Shawangunk Formation (Middle Silurian); Omhp, High Point Member of Martinsburg Formation (Upper Ordovician); Omr, Ramseyburg Member of Martinsburg Formation (Upper Ordovician). A, B, C, and D: localities mentioned in text. F: graptolite locality. 


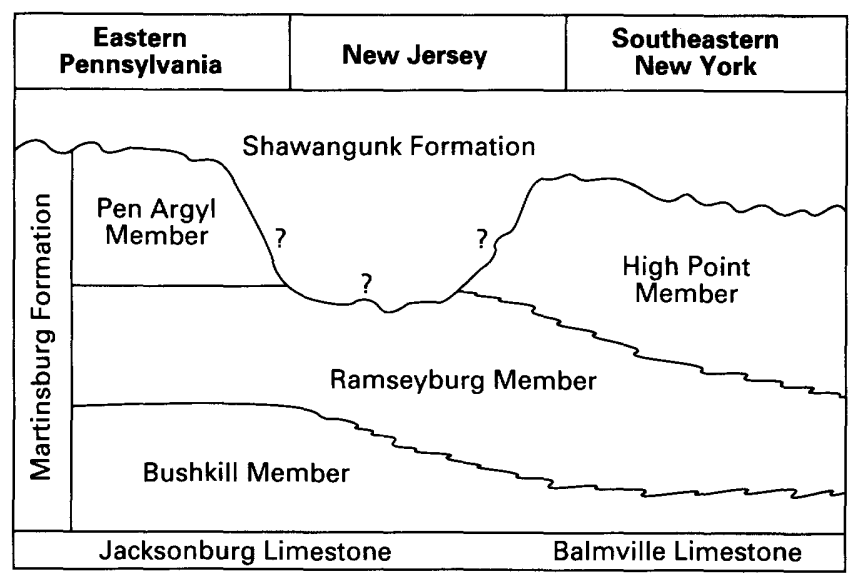

Figure B3. Schematic diagram showing the relation of the members of the Martinsburg Formation from eastern Pennsylvania to the Unionville quadrangle in southeastern New York.

much as about $5 \mathrm{ft}$ in thickness and average about $1 \mathrm{ft}$. The beds are very continuous in outcrop. Texturally, most of the graywacke is fine grained, but medium-grained sandstone occurs at places. Many beds contain the complete Bouma (1962) sequence (fig. B4), but basal cutout sequences, particularly $\mathrm{T}_{\mathrm{c} \cdot \mathrm{e}}$ sequences, are most common. Many beds contain abundant sole marks (fig. B6). It is difficult to assign the Ramseyburg to a turbidite facies of Mutti and Ricci Lucchi (1978) and Walker and Mutti (1973). The rocks have many characteristics of facies $\mathrm{C}$ (table B1), but bed thickness and continuity, grain size, and the basal cutout sequences are more typical of facies D (table B1). Certainly, the rocks of the Ramseyburg are much more "proximal" than those of the Bushkill Member, but they are not typical of the "proximal" turbidites of facies C (table B1).

The Ramseyburg is about $2,800 \mathrm{ft}$ thick in the Delaware Valley (Drake and Epstein, 1967) and about $3,500 \mathrm{ft}$ thick in the Unionville quadrangle (fig. B1). As with the Bushkill, the change is difficult to track because of the carbonate klippen in north-central New Jersey.

The Ramseyburg is also difficult to date. Drake and others (1989) estimate that it is Edenian (Caradocian) in age.

\section{PEN ARGYL MEMBER}

In the Delaware Valley the Ramseyburg grades up into the Pen Argyl Member, a unit consisting of laminated graywacke siltstone and slate, thick-bedded slate, and black slate. The beds in the laminated sequence rarely exceed a foot in thickness, although some are as much as $3 \mathrm{ft}$ thick. The black slate beds range from less than an inch to 20 inches in thickness, whereas the thick-bedded slate is commonly $5 \mathrm{ft}$ thick, though intervals as thick as $30 \mathrm{ft}$ have

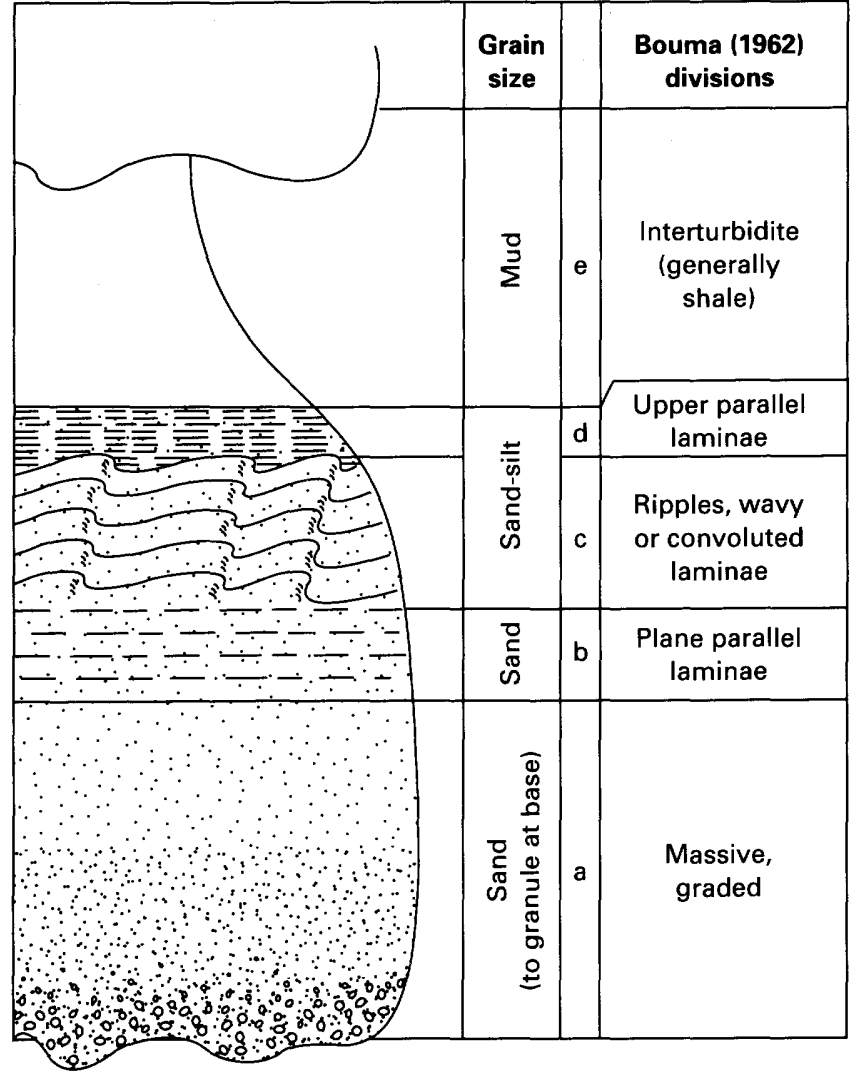

Figure B4. Ideal sequence (the Bouma sequence) of structures in a turbidite bed (modified from Middleton and Hampton, 1973).

been recognized. This rock is commercially exploited for roofing slate. Both the laminated rocks and the thickbedded slate are turbidites, but neither group has a predictable or cyclic arrangement of bedforms similar to that of sand turbidites (Bouma, 1962), and both groups are interpreted by Lash (1987) to be muddy turbidites deposited in an anoxic basin.

The Pen Argyl is estimated to be as much as $6,000 \mathrm{ft}$ thick in the Delaware Valley (Drake and Epstein, 1967). It does not crop out west of Hawk Mountain in Pennsylvania or east of the Delaware River.

The Pen Argyl contains graptolites of Edenian (Caradocian) age near its upper contact (Epstein and Berry, 1973).

\section{HIGH POINT MEMBER (HERE NAMED)}

The unit herein called the High Point Member was first recognized as a separate Martinsburg entity by Peter Lyttle (oral commun., 1983). It is characterized by thick or thick-appearing graywacke beds that have resulted from sedimentary amalgamation. At places, the graywacke contains intervals or interbeds of dark-colored shale. Much of the graywacke has a siliceous cement and typically contains rip-up clasts of dark-colored shale. The High Point lies 
Table B1. Classification of turbidite and other resedimented facies

[Modified from Walker and Mutti, 1973]

\begin{tabular}{|c|c|}
\hline Facies & Description \\
\hline 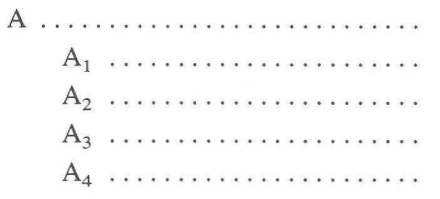 & $\begin{array}{l}\text { Coarse-grained sandstones and conglomerates. } \\
\text { Disorganized conglomerates. } \\
\text { Organized conglomerates. } \\
\text { Disorganized pebbly sandstones. } \\
\text { Organized pebbly sandstones. }\end{array}$ \\
\hline 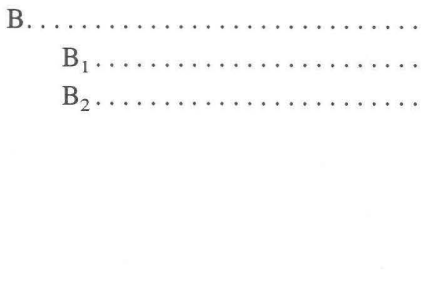 & $\begin{array}{l}\text { Medium-fine- to coarse-grained sandstones. } \\
\text { Massive sandstones having "dish" structure. } \\
\text { Massive sandstones not having "dish" structure. Most beds lack alternating } \\
\text { parallel lamination but may contain crude, subparallel, faint stratification. } \\
\text { Beds have a very high }(>10: 1) \text { sand/shale ratio, indicating that sandstones } \\
\text { are amalgamated; that is, beds are welded together without interbedded } \\
\text { shales. Beds range from tens of centimeters to about } 2 \text { meters thick and } \\
\text { have scoured bases, and most are lenticular. }\end{array}$ \\
\hline $\mathrm{C}, \ldots \ldots \ldots \ldots \ldots \ldots \ldots \ldots \ldots \ldots \ldots$ & $\begin{array}{l}\text { Medium- to fine-grained sandstones - classic "proximal" turbidites beginning with } \\
\text { Bouma division a. Strata typically are sharp, flat based, and regularly bedded, } \\
\text { and have good lateral continuity. Sandstones range from about } 10 \text { centimeters } \\
\text { to } 1 \text { meter thick and have sand/shale ratios of about } 5: 1 \text {. Amalgamation is } \\
\text { uncommon, and most sandstone beds grade up into shale (Bouma division e). } \\
\text { Most beds in a sequence begin with Bouma division a. Parallel (Bouma divi- } \\
\text { sions b and d) and ripple cross-lamination (Bouma division c) is uncommon, } \\
\text { and rock can typically be described as a } T_{\text {ae }} \text { turbidite. Facies } C \text { is not sharply } \\
\text { separated from Facies } B_{2} \text {, and there is a spectrum of beds between } B_{2} \text { and } C \text {. }\end{array}$ \\
\hline$\ldots \ldots \ldots \ldots \ldots$ & $\begin{array}{l}\text { Fine- to very fine grained sandstones and siltstones-classic "distal" turbidites } \\
\text { beginning with Bouma division b or c. Sandstone beds have sharp, flat bases, } \\
\text { are prominently graded, and are about } 1-10 \text { centimeters thick. The sand/shale } \\
\text { ratio is low, } 1: 1 \text { or less. Most sequences start with Bouma division b or c and } \\
\text { can be described as } \mathrm{T}_{\text {bcde }}, \mathrm{T}_{\text {bde }} \text {, or } \mathrm{T}_{\text {cde }} \text { turbidites, the } \mathrm{T}_{\text {cde }} \text { being the model } \\
\text { sequence. There is a gradation between turbidites of facies C and } \mathrm{D} \text {. }\end{array}$ \\
\hline E...... & $\begin{array}{l}\text { Similar to facies } \mathrm{D} \text {, but has higher sand/shale ratios, thinner, more irregular } \\
\text { beds, and more discontinuous beds in wedges and lenses. The tops of most } \\
\text { sandstone beds are not graded but are in sharp contact with overlying shales. } \\
\text { Facies is characterized by } \mathrm{T}_{\mathrm{ae}} \text { turbidites. }\end{array}$ \\
\hline $\mathrm{F} \ldots \ldots \ldots \ldots \ldots \ldots \ldots \ldots \ldots \ldots$ & Chaotic deposits formed by downslope mass movements. \\
\hline$\ldots \ldots$ & $\begin{array}{l}\text { Hemipelagic and pelagic shales and marl-silty or calcareous deposits having } \\
\text { indistinct and poorly developed lamination or distinct parallel bedding and } \\
\text { resulting from very dilute suspensions. }\end{array}$ \\
\hline
\end{tabular}

above the Ramseyburg in an unknown manner. The contact occurs between rocks that were deposited in quite different sedimentary environments. It is placed at the first appearance of thick-bedded graywacke or amalgamated graywacke containing clasts of dark-colored shale. The contact is probably gradational, as Peter Lyttle (oral commun., 1989) has reported that rocks like those herein called High Point are interbedded with rocks resembling the Ramseyburg in a unit informally called the graywacke at Pine Bush (Epstein and Lyttle, 1987) in the Pine Bush quadrangle, New York (fig. B1).

Descriptions of important outcrops follow. The Ramseyburg in the nearest good exposure to the contact, locality $\mathrm{A}$ in figure B2, is interbedded graywacke and slate in intervals 0.5 to 5 in thick. The rocks are Bouma sequence
$\mathrm{T}_{\mathrm{bc}}$ or $\mathrm{T}_{\mathrm{c} \text {-e }}$ (fig. B4) and have all the characteristics of turbidite facies D (table B1). The High Point in the nearest good exposure to the contact, locality D in figure B2, consists of three amalgamated beds having a total thickness of 57 in. Most of the graywacke is dark gray (N3) on fresh surfaces and weathers olive gray (5Y 4/1). Bed tops are marked by the scoured remnants of shale that is grayish black where fresh and pale yellowish brown (10YR 6/2) where weathered (fig. B7). The graywacke also contains abundant rip-up clasts of shale (fig. B8), some of which are as long as $7 \mathrm{in}$. The graywacke beds here have graded bases and parallel laminated tops, so are $\mathrm{T}_{\mathrm{ab}}$ turbidites (fig. $\mathrm{B} 4$ ). Another good exposure of High Point, locality B in figure B2, consists of $4 \mathrm{ft}$ of graywacke, which is actually two amalgamated beds, the top of the lower bed being 


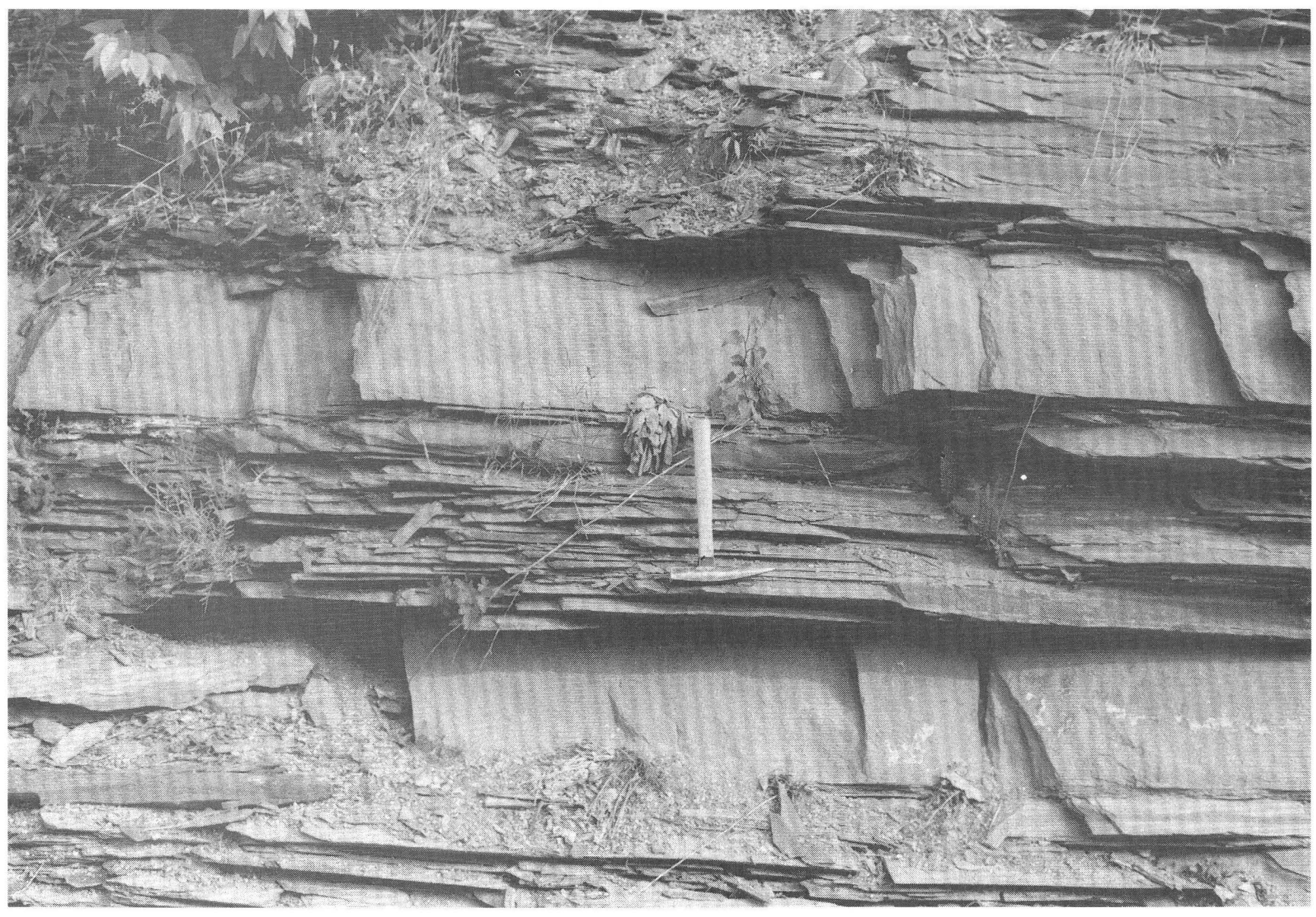

Figure B5. Typical exposure of the Ramseyburg Member of the Martinsburg Formation. Hammer is 12.75 inches long.

marked by sparse remnants of shale. Four feet of dark shale underlies the graywacke.

Exceptional exposures of High Point occur at locality $\mathrm{C}$ in figure $\mathrm{B} 2$. In one exposure, a bed of graywacke is at least 63 in thick. Its bottom is not exposed, and there is no evidence of amalgamation. In another exposure, a 70-in bed is amalgamated to an 18-in bed below and a 24-in bed above. Grading was the only sedimentary structure noted, so the rocks here are $\mathrm{T}_{\mathrm{a}}$ turbidites.

Few long exposures of High Point were found. One of the best (fig. B9) contains only a minor amount of shale. In other areas, such as in High Point State Park and along Interstate 84 (fig. B2), dark shale is fairly abundant.

The High Point is characterized by abundant load casts, some of which are very large (fig. B10). Most of the rock in the High Point is silica cemented, but many beds in the lower part of the unit contain carbonate in their matrix.

Much of the High Point can be assigned to turbidite facies B (table B1), but other parts, particularly those that contain interbedded shale, are better assigned to turbidite facies C. In any case, the rocks were deposited in a much higher energy environment than the other parts of the Martinsburg Formation.
The High Point may be as much as 4,500 $\mathrm{ft}$ thick in the Unionville quadrangle, but this is only an estimate. Berry (1971) described four species of graptolites collected from the High Point $50-100 \mathrm{ft}$ stratigraphically below the Shawangunk Formation along Interstate 84 in the Port Jervis South quadrangle (fig. B2). He assigned these graptolites to his Climacograptus spiniferus zone, suggesting that at least this part of the High Point is Edenian (Caradocian) in age. More recently, Parris and Cruikshank (in press) collected three specimens of Orthograptus quadrimucronatus from the High Point about $750 \mathrm{ft}$ stratigraphically below the Shawangunk Formation along New Jersey Route 519 in the Port Jervis South quadrangle (fig. B2). It is, however, impossible to assign a zone or age on the basis of one species. It would appear, therefore, that at least the upper part of the High Point is the same age as the Pen Argyl Member in the Delaware Valley.

The High Point is unconformably overlain by rocks of the Shawangunk Formation of probable Middle Silurian age. The low-angle unconformity is marked by an interval, less than $1 \mathrm{ft}$ thick, of diamictite interpreted to be a colluvial deposit by Epstein and Lyttle (1987). 


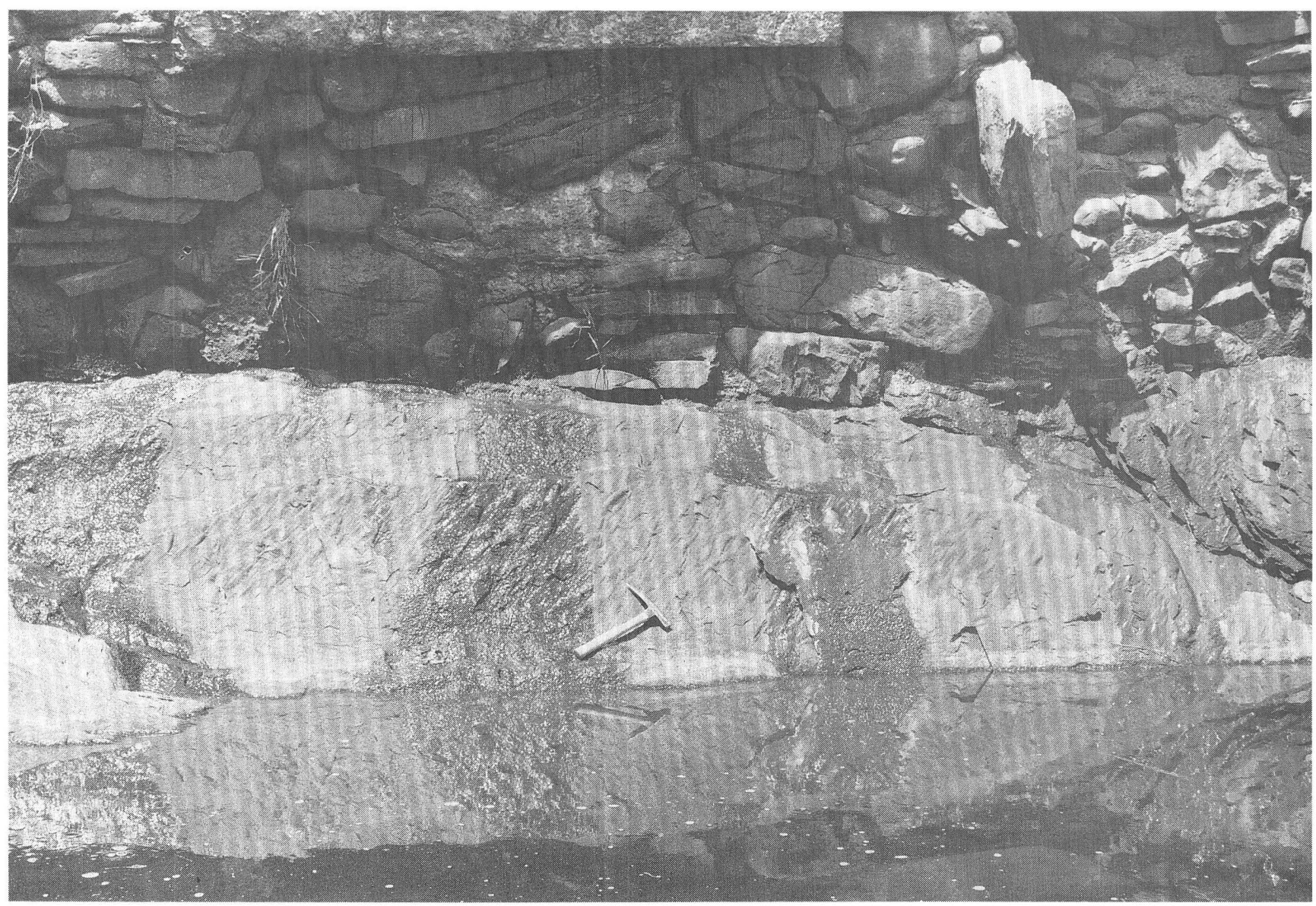

Figure B6. Abundant load casts on the bottom of a Ramseyburg graywacke bed. Bed dips toward viewer and is overturned. Hammer is 12.75 inches long.

\section{REGIONAL RELATIONS}

McBride (1962), on the basis of paleocurrent indicators, first suggested that the Martinsburg foreland basin was filled from the northeast. Data reported herein support that

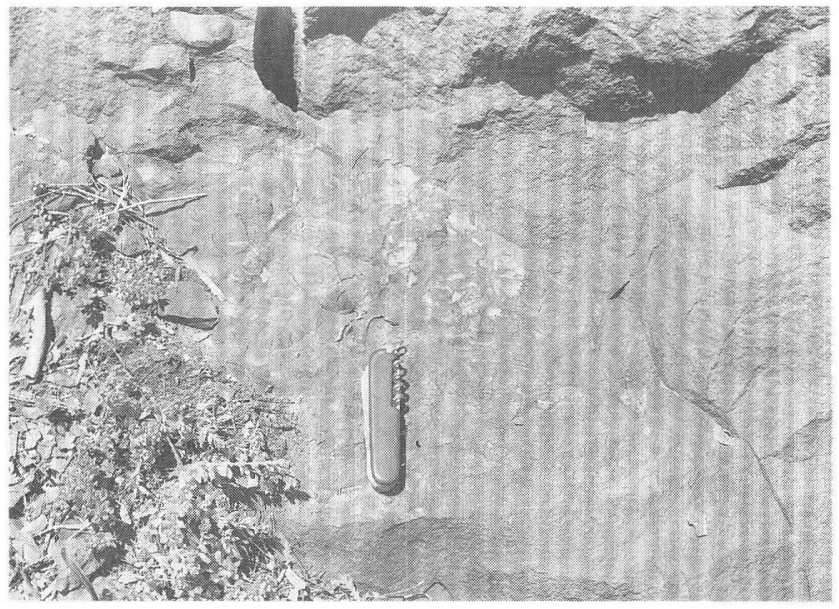

Figure B7. Scoured shale remnants on the top of a High Point graywacke bed. Knife is 3.5 inches long. concept, as the Martinsburg lithology clearly becomes more proximal to the northeast. Much of the Bushkill Member is replaced by the turbidite facies $C$ deposits of the Ramseyburg Member. The Bushkill-Ramseyburg sequence has been interpreted as unconfined sheet flows or as turbidites

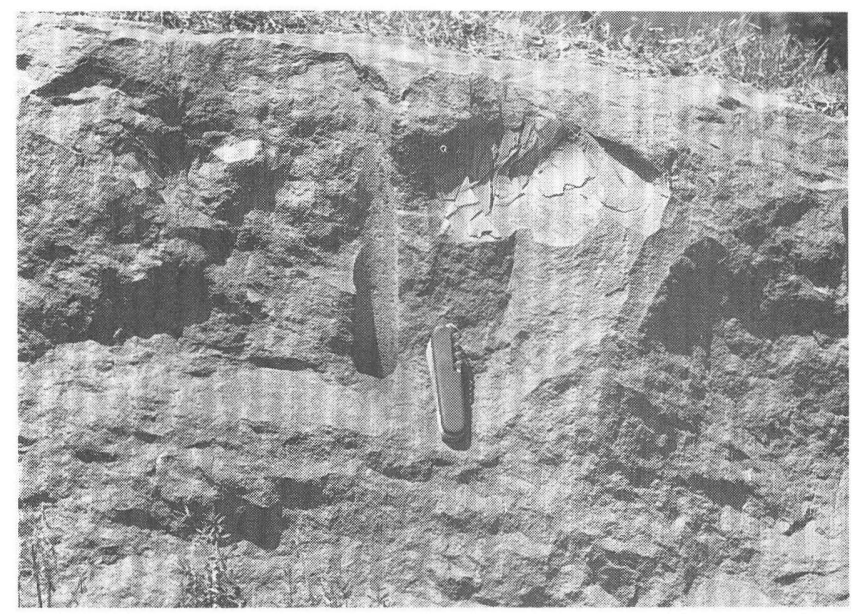

Figure B8. Rip-up clasts of shale in High Point graywacke. Knife is 3.5 inches long. 




Figure B9. Outcrop of typical High Point. Two thin shale interbeds occur in the lower right of the photograph. The thin-bedded material in the upper part of the photograph is graywacke. Hammer is 12.75 inches long. deposited within wide, shallow channels (Lash, 1987). The high proportion of basal cutout sequences supports the latter concept. Much of the Bushkill-Ramseyburg interval in northernmost New Jersey and adjacent New York is replaced by the much more proximal turbidite facies $\mathrm{B}$ and lesser C High Point Member. Farther to the northeast in the Pine Bush quadrangle (fig. B1), Ramseyburg-like rocks occur only within the High Point-like graywacke in the Pine Bush sequence (Epstein and Lyttle, 1987). Yet another Martinsburg unit, the shale and graywacke at Mamakating of Epstein and Lyttle (1987), occurs above the Pine Bush. Their brief description suggests that this unit was deposited in a lower energy environment than the High Point. The Pen Argyl Member in the Delaware Valley, the High Point, and the shale and graywacke at Mamakating (Berry, 1971) all contain graptolites of the Climacograptus spiniferus zone, suggesting that they all might be of about the same age, although they were deposited in radically different sedimentary environments. The Martinsburg would be an excellent field laboratory to study the evolution of foreland basins.

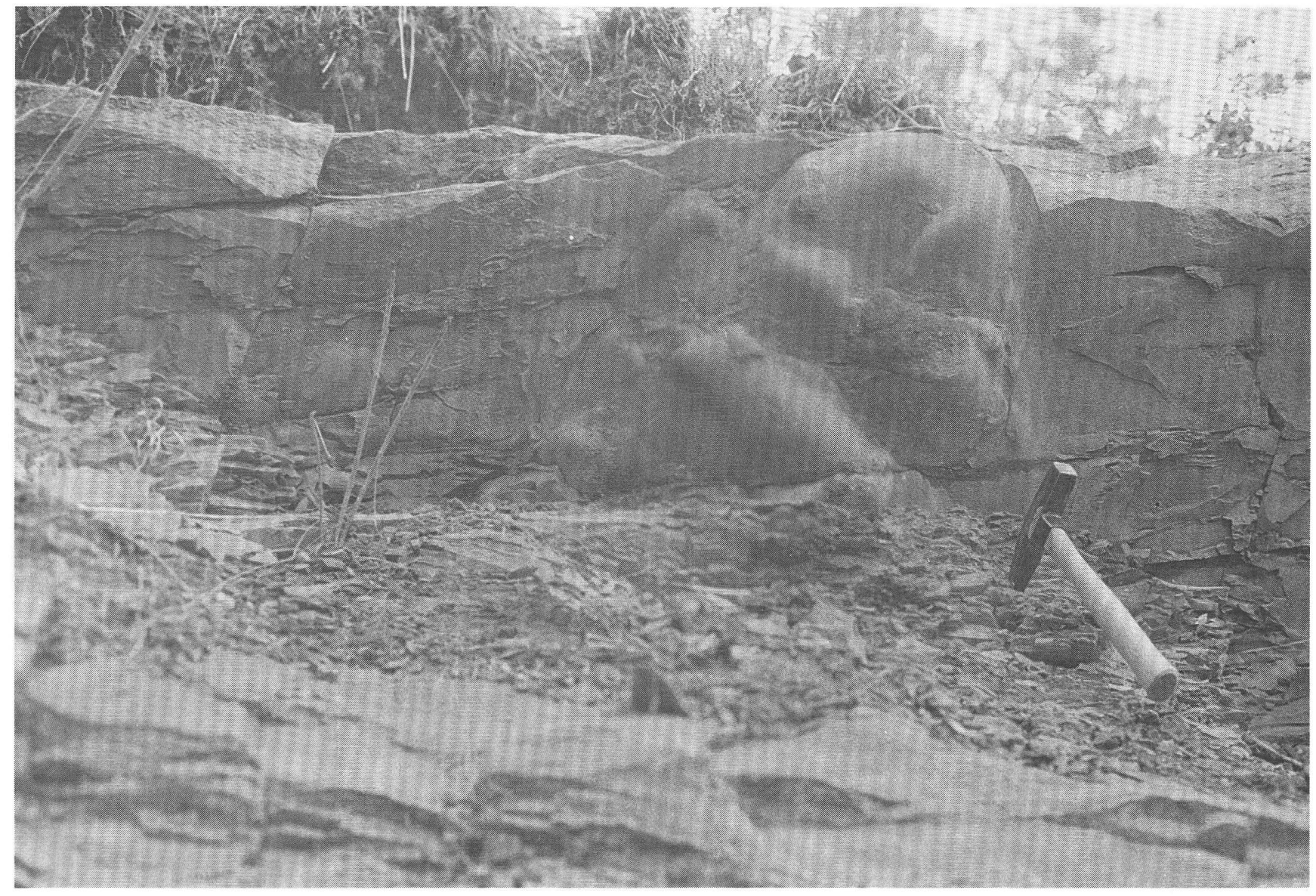

Figure B10. Very large load casts in the High Point. Hammer is 12.75 inches long. 


\section{REFERENCES CITED}

Berry, W.B.N., 1971, Late Ordovician graptolites from southeastern New York: Journal of Paleontology, v. 45, p. 633-640.

Bouma, A.H., 1962, Sedimentology of some flysch deposits: Amsterdam, Elsevier, 168 p.

Drake, A.A., Jr., 1969, Precambrian and Lower Paleozoic geology of the Delaware Valley, New Jersey-Pennsylvania, in Subitzky, Seymour, ed., Geology of selected areas in New Jersey and eastern Pennsylvania and Guidebook of excursions: New Brunswick, N.J., Rutgers University Press, p. 51-131.

Drake, A.A., Jr., and Epstein, J.B., 1967, The Martinsburg Formation (Middle and Upper Ordovician) in the Delaware Valley, Pennsylvania-New Jersey: U.S. Geological Survey Bulletin 1244-H, 16 p.

Drake, A.A., Jr., Epstein, J.B., and Aaron, J.M., 1969, Geologic map and sections of parts of the Portland and Belvidere quadrangles, New Jersey-Pennsylvania: U.S. Geological Survey Miscellaneous Investigations Map I-552, scale $1: 24,000$.

Drake, A.A., Jr., Kastelic, R.L., Jr., and Lyttle, P.T., 1985, Geologic map of the eastern parts of the Belvidere and Portland quadrangles, Warren County, New Jersey: U.S. Geological Survey Miscellaneous Investigations Map I-1530, scale 1:24,000.

Drake, A.A., Jr., and Lyttle, P.T., 1985, Geologic map of the Blairstown quadrangle, Warren County, New Jersey: U.S. Geological Survey Geologic Quadrangle Map GQ-1585, scale $1: 24,000$.

Drake, A.A., Jr., Sinha, A.K., Laird, Jo, and Guy, R.E., 1989, The Taconic orogen, in Hatcher, R.D., Jr., Thomas, W.A., and Viele, G.W., eds., The Appalachian-Ouachita orogen in the U.S. (The geology of North America, v. F-2): Boulder, Colo., Geological Society of America, p. 101-177.

Epstein, J.B., and Berry, W.B.N., 1973, Graptolites from the Martinsburg Formation, Lehigh Gap, Pennsylvania: U.S. Geological Survey Journal of Research, v. 1, no. 1, p. $33-37$.

Epstein, J.B., and Lyttle, P.T., 1987, Structure and stratigraphy above, below, and within the Taconic unconformity, southeastern New York, in Waines, R.H., ed., New York State
Geological Association annual meeting, 59th, Kingston, N.Y., November 6-8, 1987, Field trip guidebook, p. C1-C78.

Fisher, D.W., Isachsen, Y.W., and Rickard, L.V., 1970, Geologic map of New York State, Lower Hudson sheet: New York State Museum and Science Service Map and Chart Series 15, scale 1:250,000.

Jordan, T.E., 1981, Thrust loads and foreland basin evolution, Cretaceous, Western United States: American Association of Petroleum Geologists Bulletin, v. 65, p. 2506-2520.

Lash, G.G., 1987, Sedimentology and possible paleooceanographic significance of mudstone turbidites and associated deposits of the Pen Argyl Member, Martinsburg Formation (Upper Ordovician), eastern Pennsylvania: Sedimentary Geology, v. 54, p. 113-135.

Lash, G.G., and Drake, A.A., Jr., 1984, The Richmond and Greenwich slices of the Hamburg klippe in eastern Pennsylvania-Stratigraphy, sedimentology, structure, and plate tectonic implications: U.S. Geological Survey Professional Paper 1312, 40 p.

McBride, E.F., 1962, Flysch and associated beds of the Martinsburg Formation (Ordovician), central Appalachians: Journal of Sedimentary Petrology, v, 32, no. 1, p. 39-91.

Middleton, G.V., and Hampton, M.A., 1973, Sediment gravity flows; Mechanics of flow and deposition, in Middleton, G.V., and Bouma, A.H., co-chairmen, Turbidites and deepwater sedimentation: Los Angeles, Society of Economic Paleontologists and Mineralogists, Pacific Section, p. 1-38.

Mutti, Emiliano, and Ricci Lucchi, F.R., 1978, Turbidites of the northern Apennines; Introduction to facies analysis: American Geological Institute Reprint Series 3, p. 125-166.

Offield, T.W., 1967, Bedrock geology of the Goshen-Greenwood Lake area, New York: New York State Museum and Science Service Map and Chart Series 9, 78 p.

Parris, D.C., and Cruikshank, K.M., in press, New biostratigraphic information on the Ordovician Martinsburg Formation of New Jersey and adjacent areas: New Jersey State Museum Investigation.

Walker, R.G., and Mutti, Emiliano, 1973, Turbidite facies and facies associations, in Middleton, G.V., and Bouma, A.H., co-chairmen, Turbidites and deep-water sedimentation: Los Angeles, Society of Economic Paleontologists and Mineralogists, Pacific Section, p. 118-157. 


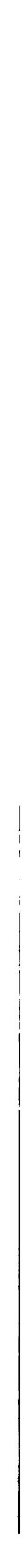


Chapter C

\title{
The Mount Eve Granite (Middle Proterozoic) of Northern New Jersey and Southeastern New York
}

\author{
By AVERY ALA DRAKE, JR., and JOHN N. ALEINIKOFF, \\ U.S. Geological Survey, and RICHARD A. VOLKERT, \\ New Jersey Geological Survey
}




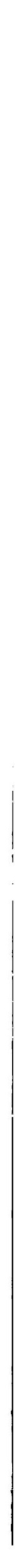




\title{
CONTENTS
}

\author{
Abstract C1 \\ Introduction $\mathbf{C 1}$ \\ Regional Geology C1 \\ Mount Eve Granite C3 \\ Petrography and Field Relations C3 \\ Chemistry C5 \\ U-Pb Geochronology C6 \\ Conclusions C7 \\ References Cited C10
}

FIGURES

C1, C2. Maps showing:

C1. Distribution of rocks older than 1 billion years in Eastern North America C2

C2. Distribution of Middle Proterozoic rocks of the Reading Prong in northernmost New Jersey and immediately adjacent New

York C3

C3, C4. Generalized geologic maps of:

C3. Parts of the Pine Island (New York-New Jersey), Unionville

(New York-New Jersey), and Hamburg (New Jersey) 7.5-minute quadrangles showing distribution of the Mount Eve Granite C4

C4. Southeast corner of the Newton East 7.5-minute quadrangle showing location of an undeformed granitoid that may correlate with the Mount Eve Granite C5

C5. Quartz-alkali feldspar-plagioclase plot of Mount Eve Granite C6

C6-C9. Photographs showing:

C6. Typical texture of Mount Eve Granite C6

C7. Mount Eve Granite intruding amphibolite C6

C8. Lenticular inclusion of potassic feldspar gneiss in Mount Eve Granite C7

C9. Inclusions of amphibolite in Mount Eve Granite showing a slight preferred orientation $\mathbf{C 7}$

C10. Normative feldspar plot of Mount Eve Granite C8

C11. Concordia diagram for zircons from the Mount Eve Granite C9

\section{TABLES}

C1. Chemical analyses and CIPW norms of Mount Eve Granite $\mathbf{C 8}$

C2. Uranium-lead concentration and isotopic composition data from zircon from the Mount Eve Granite 


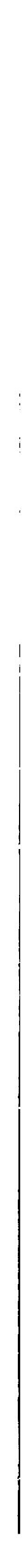




\title{
The Mount Eve Granite (Middle Proterozoic) of Northern New Jersey and Southeastern New York
}

\author{
By Avery Ala Drake, Jr., John N. Aleinikoff, and Richard A. Volkert
}

\begin{abstract}
The Mount Eve Granite forms small intrusive bodies in a limited area of northern New Jersey and adjacent New York. Most of the rock is syenogranite, and the unit is interpreted to be a Caledonian I-type granite. The Mount Eve cuts across the structures in the metamorphic country rocks, and is itself undeformed. U-Pb data from abraded zircons plotted on a concordia diagram give an age of $1,020 \pm 4 \mathrm{Ma}$, which is interpreted to be the crystallization age of the Mount Eve Granite. The lower intercept $(280 \pm 190 \mathrm{Ma})$ suggests lead loss related to the Alleghanian orogeny, but the large uncertainty permits disturbance of the zircons during any event during the Phanerozoic. The Mount Eve is a postkinematic intrusion emplaced during postcollision uplift. It, therefore, gives an upper bound for Grenvillian orogenesis in the Reading Prong. U-Pb systematics of unabraded zircons suggest an episode of lead loss coincident with the Avalonian event in southeastern New England and adjacent New York.
\end{abstract}

\section{INTRODUCTION}

Three suites of granitoid intrusive rocks occur in the New Jersey Highlands segment of the Reading Prong (figs. $\mathrm{C} 1, \mathrm{C} 2$ ). The bulk of these rocks belong to the synkinematic Byram (Drake, 1984) and Lake Hopatcong (Drake and Volkert, chap. A, this vol.) Intrusive Suites, which form small to large, essentially conformable sheets within hornblende granulite facies country rocks that range from about $200 \mathrm{ft}$ (feet) to as much as $4 \mathrm{mi}$ (miles) long. The granitoid herein called Mount Eve Granite, on the other hand, forms small stocks that have dikelike and sill-like apophyses. The Mount Eve is restricted to the Pine Island, Unionville, Wawayanda, and Hamburg 7.5-minute quadrangles of New York and New Jersey (fig. C2). A small body of granitoid in the Newton East quadrangle (fig. C2) resembles the Mount Eve but differs from it in both petrography and chemistry. The purposes of this paper are to describe the Mount Eve Granite and to discuss its importance in deciphering the Grenvillian history of the Reading Prong.

Manuscript approved for publication July 19, 1990.

\section{REGIONAL GEOLOGY}

The Losee Metamorphic Suite appears to constitute the oldest sequence of Middle Proterozoic rocks in the New Jersey Highlands. Parts of the Losee are well layered and foliated; other parts are poorly foliated granofels, and still others are granitoid or pegmatitic. Parts of the Losce contain fairly abundant amphibolite. The Losee rocks are very soda rich and have been interpreted to be metamorphosed quartz keratophyre and perhaps some trondhjemite intrusions (Drake, 1984).

Closely associated with the Losee are charnockitic rocks. Some of these rocks have conspicuous alternating light and dark layers and have been interpreted to result from the high-grade metamorphism and anatexis of amphibolite-rich parts of the Losee Metamorphic Suite (Drake, 1984). A perplexing problem of these rocks is the general sparsity of orthopyroxene. Many rocks that have all the other attributes of charnockite lack hypersthene. Other charnockitic rocks are massive and have igneous textures. These rocks are interpreted to be enderbites. It appears that the charnockitic suite in the New Jersey Highlands includes both metamorphosed volcanic rocks and intrusions.

The Losee and charnockitic rocks are unconformably overlain by a sequence of calcareous and quartzofeldspathic metasedimentary rocks. Calcareous rocks in the area of this report include marble and pyroxene (diopside) gneiss (fig. C3). The marble has traditionally been called Franklin Limestone (Spencer and others, 1908). Hague and others (1956) found that the marble in its type area, the Franklin 7.5-minute quadrangle (fig. C2), occurs in two major layers separated by a unit of potassic feldspar gneiss. They termed these layers the Franklin and Wildcat bands of marble and mapped them into the Pine Island quadrangle (fig. C2), where they are covered by lower Paleozoic sedimentary rocks. Detailed geologic mapping in connection with the new geologic map of New Jersey (R.A. Volkert and A.A. Drake, Jr., unpub. data) confirms the work of Hague and others (1956), and the Franklin Limestone is here redefined as Franklin Marble and revised to include only the Franklin band of marble. The Wildcat band of marble is herein formally named the Wildcat Marble. The lithic designation 


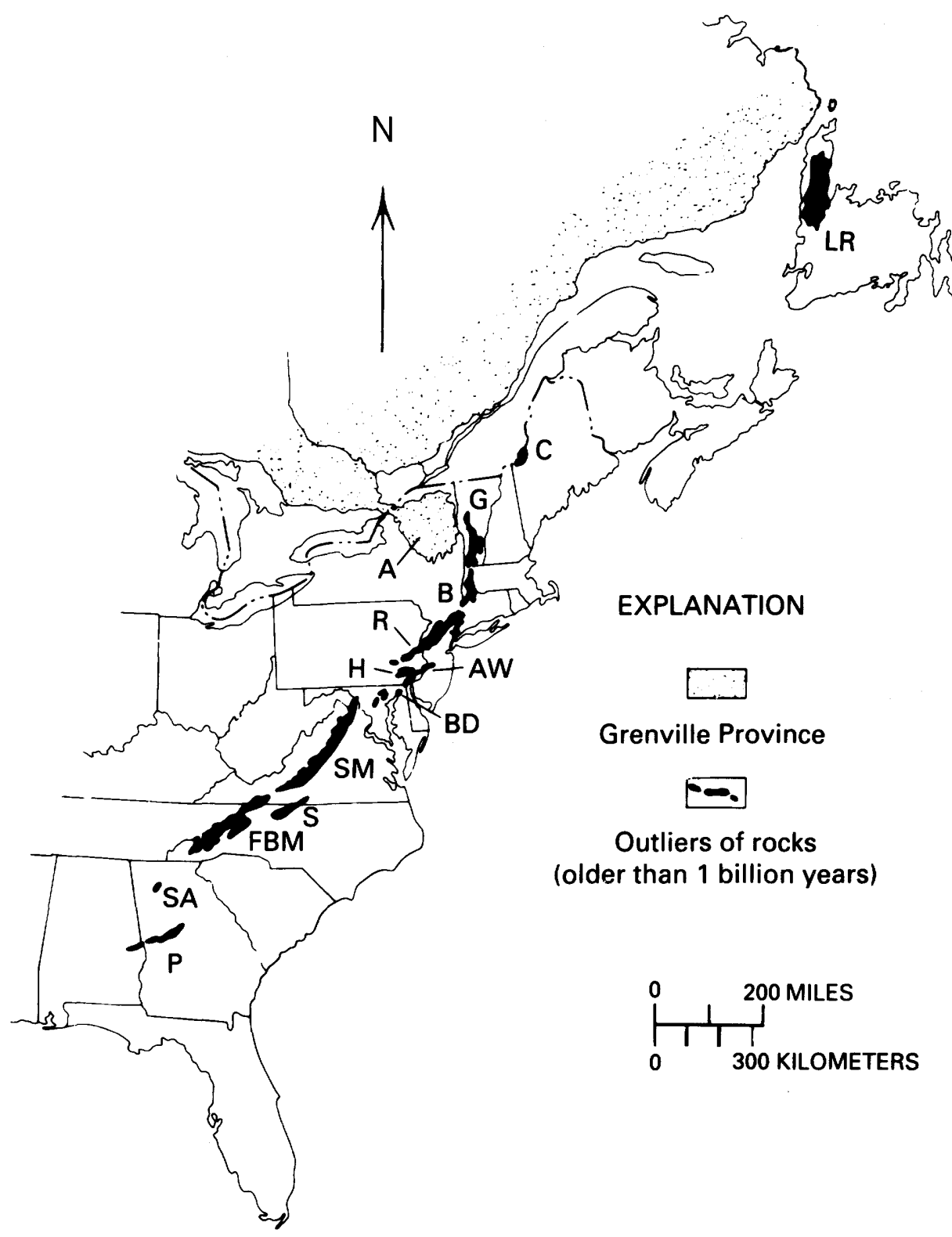

Figure C1. Distribution of rocks older than 1 billion years in Eastern North America. LR, Long Range; C, Chain Lakes massif; G, Green Mountain massif; A, Adirondack massif; B, Berkshire massif; R, Reading Prong; H, Honey Brook upland; AW, Avondale-West Chester massif; BD, Baltimore "gneiss domes"; SM, Shenandoah massif; S, Sauratown Mountains window; FBM, French Broad massif; SA, Salem Church anticline; and P, Pine Mountain window. Modified from Drake (1984).

"marble" is preferred to "Limestone" because the rock is marble.

Pyroxene gneiss is highly variable in composition and may contain as much as 90 percent diopside or as much as 80 percent plagioclase. That on Pochuck Mountain (fig. C3) is quite salic and contains layers of quartzite.

Quartzofeldspathic gneiss includes a highly heterogeneous unit of biotite-quartz-feldspar gneiss and potassic feldspar gneiss. The more aluminous parts of both units contain sillimanite. The potassic feldspar gneiss on Pochuck Mountain (fig. C3) is characterized by quartz-sillimanite lenses as long as 3 in (inches). The biotite-quartz-feldspar gneiss is interpreted to be a metamorphosed graywackelike sand (Drake, 1984). Much of the potassic feldspar gneiss is interpreted to be a meta-arkose; other parts, however, are magnetite rich and resemble metamorphosed iron forma- 

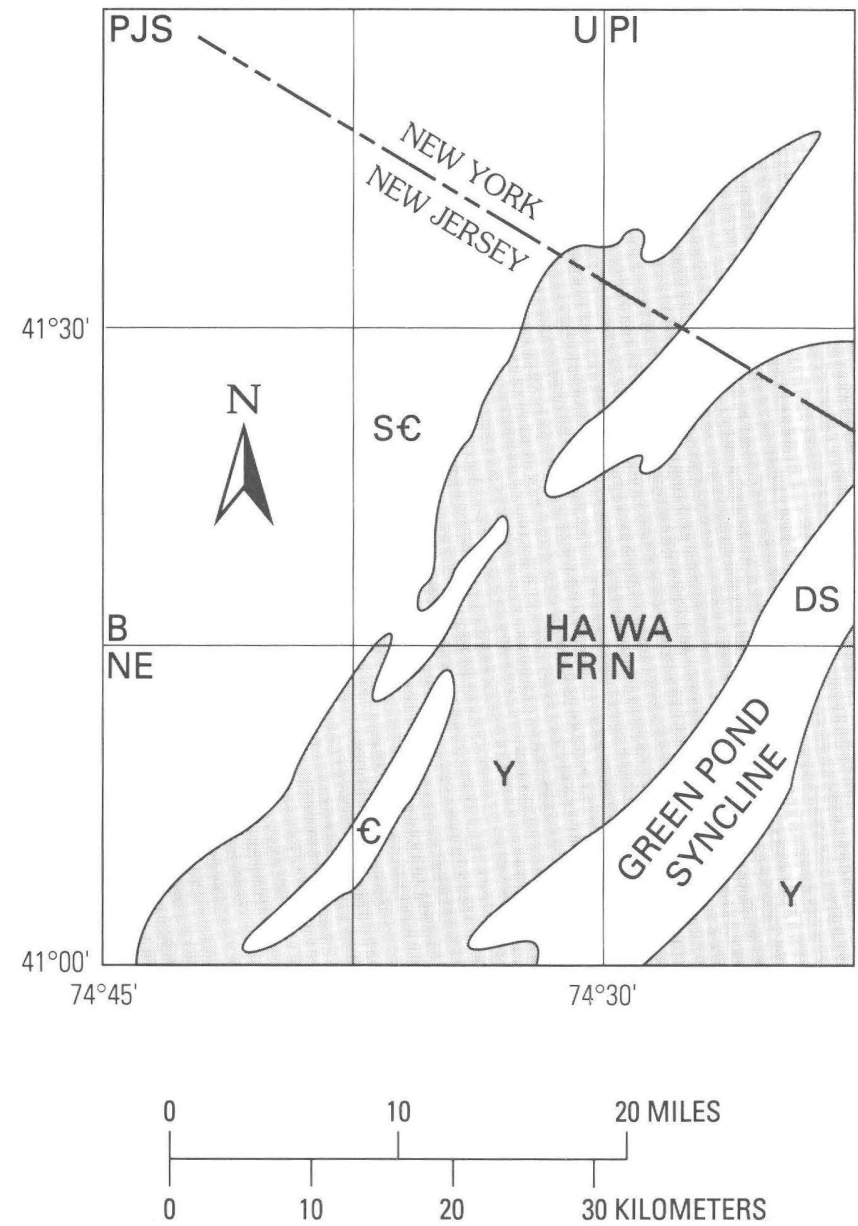

Figure C2. Distribution of Middle Proterozoic rocks, $Y$, of the Reading Prong in northernmost New Jersey and immediately adjacent New York; $€$, Cambrian rocks; $S €$, Cambrian, Ordovician, Silurian rocks; DS, Silurian and Devonian rocks. Quadrangles (7.5-minute) are as follows: PJS, Port Jervis South; U, Unionville; PI, Pine Island; B, Branchville; HA, Hamburg; WA, Wawayanda; NE, Newton East; FR, Franklin; and N, Newfoundland.

tion. Some workers (Grauch and Ludwig, 1980) have interpreted the potassic feldspar gneiss to be metamorphosed rhyolite, but many layers of the rock approach quartzite in composition, and a volcanic origin does not seem likely. The rocks, however, have magnetite-uraniumrare earth deposits that have a high barium content and, therefore, may well contain an exhalitive component.

Amphibolite occurs with all the other rock units. Much is probably metasedimentary, as it occurs in uniform layers with the metasedimentary rocks. Small enclaves within other amphibolite bodies have coarsely crystalline igneous textures, so are probably metagabbro. Still other bodies, such as that on the south border of figure $\mathrm{C} 3$, contain relict pillow structures (Hague and others, 1956; Volkert and Drake, 1986) and are probably metavolcanic.
Three phases of folds have been mapped in the New Jersey Highlands (Drake and others, 1985). These folds deform compositional layering and foliation marked by hornblende and feldspar crystals as well as lens-shaped lithologic units that probably resulted from regional transposition. None of the three mapped phases are first folds. The only evidence for earlier deformation is provided by the foliation and the regional transposition. The rocks of the Byram and Lake Hopatcong Intrusive Suites were emplaced synkinematically during the event, resulting in the oldest mapped folds.

\section{MOUNT EVE GRANITE}

The Mount Eve Granite is herein named for Mount Eve, Orange County, N.Y., in the Pine Island 7.5-minute quadrangle (figs, C2, C3), which is designated the type area. It also crops out on Mount Adam and in bodies both northeast and southwest of the type area. Intrusive bodies are abundant on Pochuck Mountain, and small bodies intrude the Franklin Marble near Amity (fig. C3). The granite was first recognized by Mather (1843), was later described by Kemp and Hollick (1894), and was mapped by Ries (1895). The name was first used by Hague and others (1956), although there is no evidence that they meant to formalize it. Offield (1967) mapped and described the granite, but did not use the name Mount Eve. The name Mount Eve Granite as used by Hague and others (1956) is here accepted for use by the U.S. Geological Survey.

Hague and others (1956) mapped a small granite body to the southeast of Lake Mohawk in the Newton East 7.5-minute quadrangle (figs. C2, C4). This granite is not deformed and physically resembles the Mount Eve, but it differs from the Mount Eve considerably, both petrographically and chemically (see below).

The Mount Eve intrudes all the other map units in the Pine Island, Unionville, Wawayanda, and Hamburg quadrangles (fig. C3). The body in the Newton East quadrangle intrudes strongly foliated and lineated hornblende granite of the Byram Intrusive Suite.

\section{Petrography and Field Relations}

The Mount Eve Granite is a coarse- to mediumgrained, light-gray rock containing microcline or microcline microperthite, quartz, oligoclase, hornblende, and biotite. Allanite is a common accessory mineral, as is magnetite. Most of the rock is syenogranite, reflecting the high content of potassic feldspar (fig. C5). The one specimen from the Newton East quadrangle is, however, granodiorite.

The Mount Eve Granite is undeformed (fig. C6), but at many places near contacts it has both a flow foliation and lineation. The fabric contains no evidence of either strain or recrystallization. There is abundant evidence at both map 


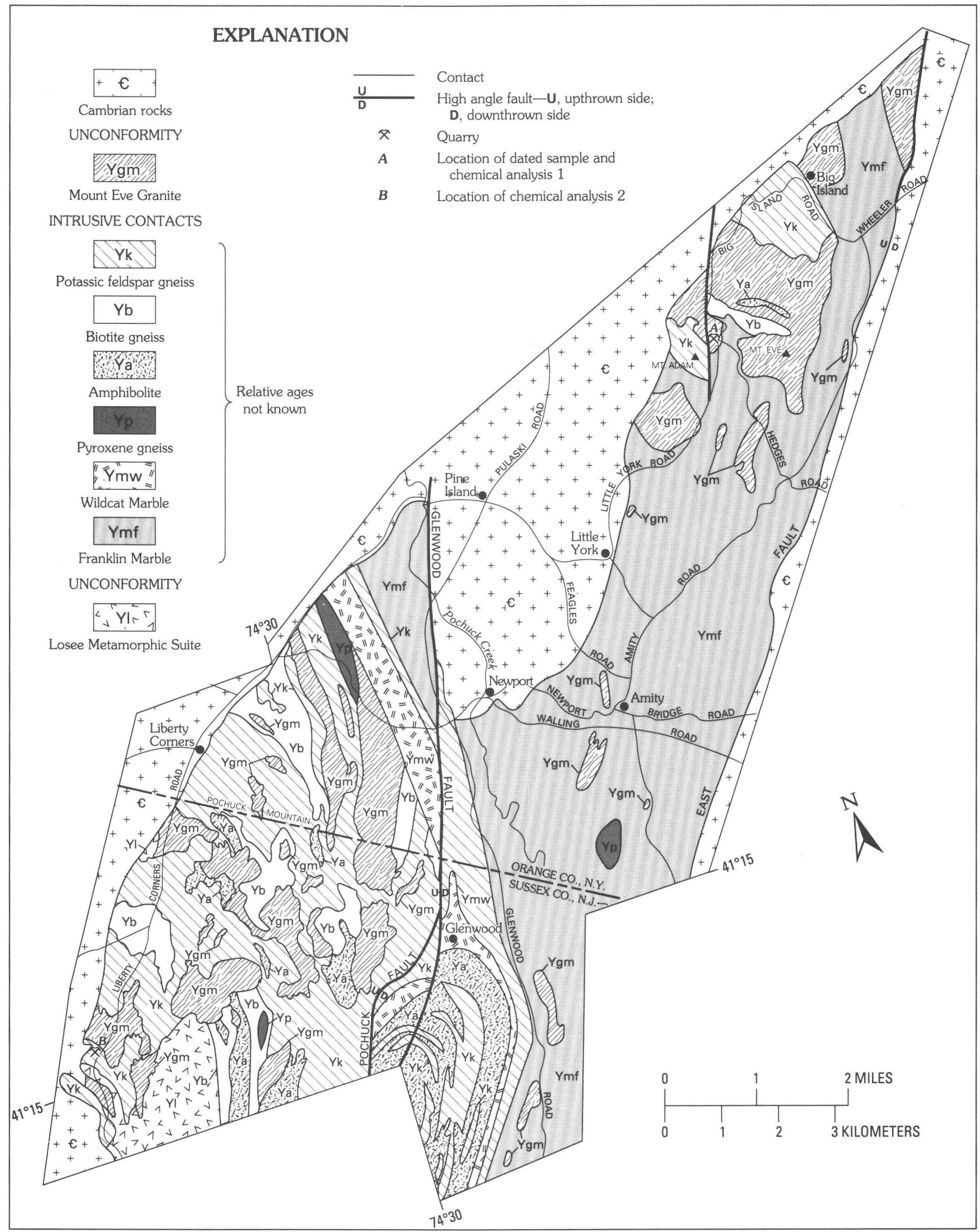

Figure C3. Generalized geologic map of parts of the Pine Island (New York-New Jersey), Unionville (New York-New Jersey), and Hamburg (New Jersey), Wawayanda (New Jersey-New York), 7.5-minute quadrangles showing distribution of the Mount Eve Granite. Geology of the Unionville quadrangle and the New Jersey part of the Pine Island quadrangles by A.A. Drake, Jr. (unpub. data). Geology of the Wawayanda and Hamburg quadrangles by R.A. Volkert (unpub. data). Geology of the New York part of the Pine Island quadrangle modified from Offield (1967). 


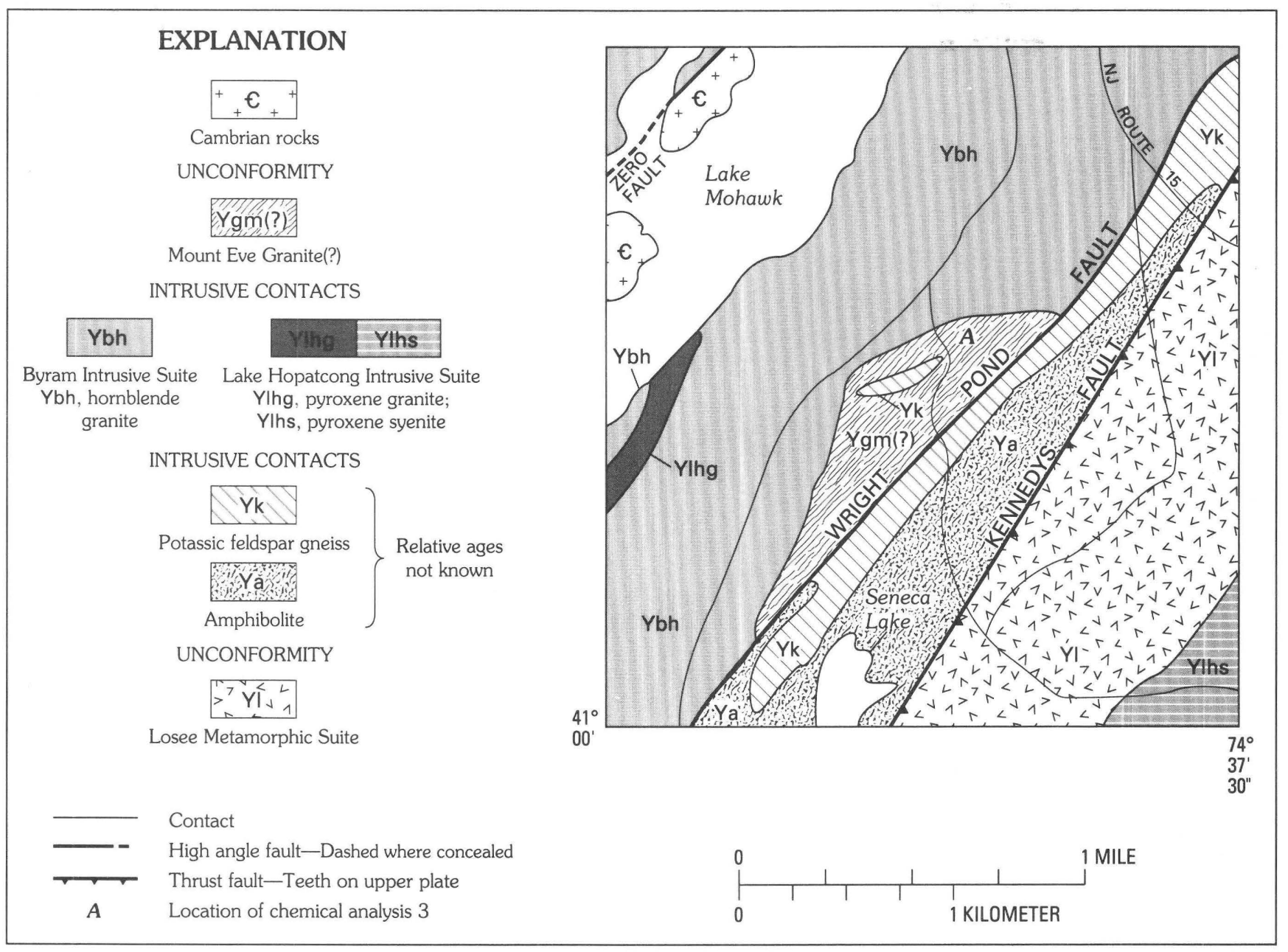

Figure C4. Generalized geologic map of the southeast corner of the Newton East 7.5-minute quadrangle showing location of an undeformed granitoid that may correlate with the Mount Eve Granite. Geology modified from Hague and others (1956).

(fig. C3) and outcrop scales (figs. C7, C8) that the granite cuts across the layering, foliation, and folds in the metamorphic rocks. The Mount Eve contains abundant inclusions of the country rocks (figs. C7-C9).

There is no evidence of either chilling against or reaction with the country rocks other than marble, although fairly abundant allanite-bearing pegmatites suggest that the magma was fairly fluid, as shown by contact aureoles in marble that are rich in chondrodite, scapolite, and other hydrous phases.

Contact relations of the granitoid in the Newton East quadrangle could not be determined, but the body of potassic feldspar gneiss shown within the granite was probably engulfed. The granite does not have the strong penetrative fabric of the surrounding hornblende granite.

\section{Chemistry}

The limited amount of chemical data pertaining to the Mount Eve Granite are presented in table $\mathrm{C} 1$ and classified in figure $\mathrm{C} 10$. The sample from the Mount Eve quarry is a metaluminous granite, whereas the sample from Pochuck Mountain is corundum normative and is a peraluminous granite. Analyses of many more data will be needed to properly classify the Mount Eve Granite.

Chemistry strongly suggests that the undeformed granite in the Newton East quadrangle is not Mount Eve Granite, and unless further chemical work shows a bimodal distribution of each type, the rocks are probably not petrogenetically related. 


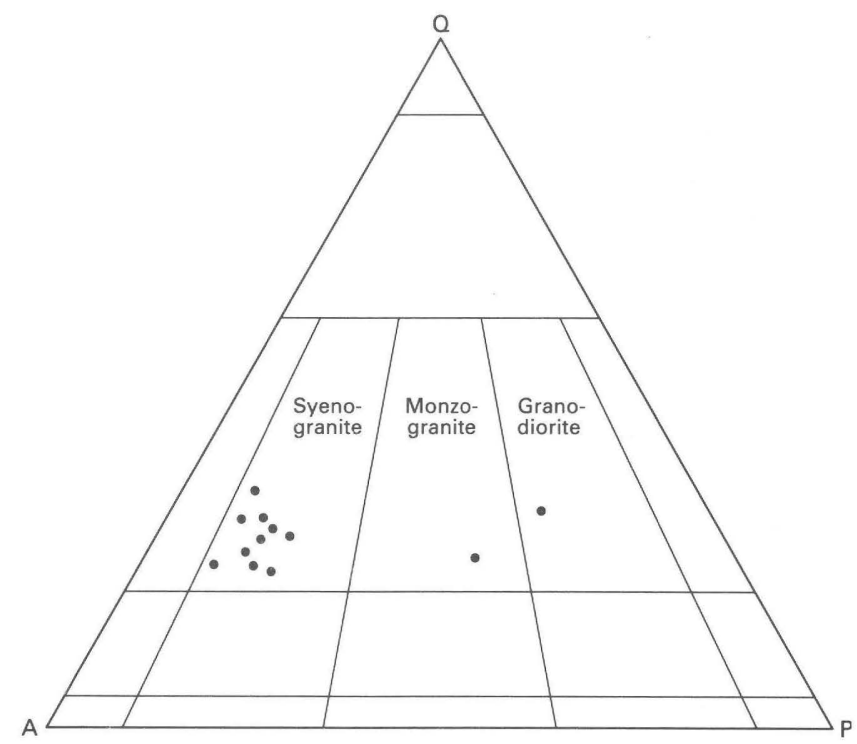

Figure C5. Quartz-alkali feldspar-plagioclase plot (Streckeisen, 1976) of 12 samples of Mount Eve Granite.

\section{U-Pb Geochronology}

Zircons were separated from about $11.5 \mathrm{lb}$ (pounds) of granite collected from a small, abandoned quarry on the east side of Mt. Adam (locality A in fig. C3). Most of the zircons are light to medium brown; some are gemlike and nearly clear. Length-to-width ratios range from 1 to 7 , and lighter grains tend to be more acicular and doubly terminated. All grains have an adamantine luster. The smooth

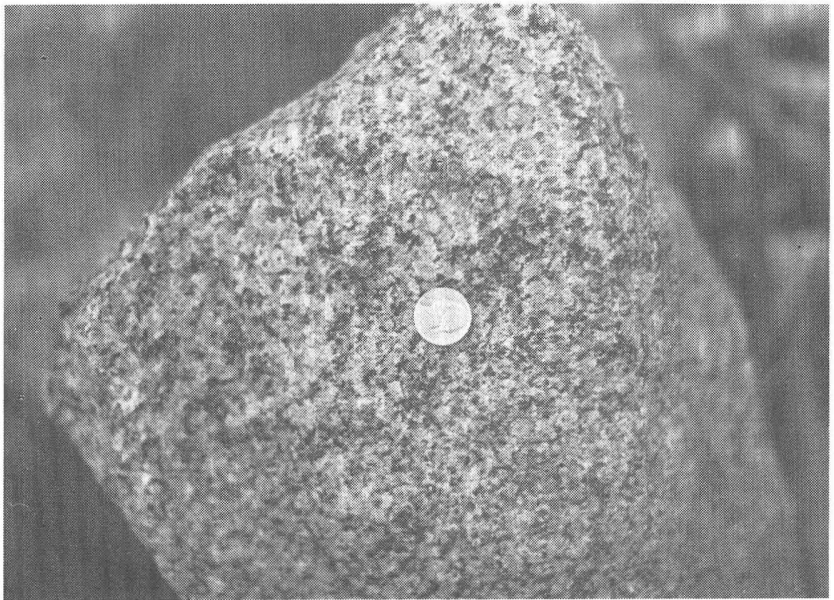

Figure C6. Typical texture of Mount Eve Granite in quarry in the saddle between Mounts Adam and Eve (loc. A in fig. C3). Coin is 0.75 inch in diameter. faces and sharp interfacial angles on all grains indicate that these crystals have not been damaged or deformed.

Seven size fractions of zircon were analyzed for uranium and lead concentrations and lead isotopiccompositions (table $\mathrm{C} 2$ ). In all cases, only the least magnetic, light-brown to clear zircons from each size fraction were analyzed. Zircons from the three coarse fractions, two of which were composed of handpicked, clear, elongate grains, were abraded to remove weak or damaged areas.

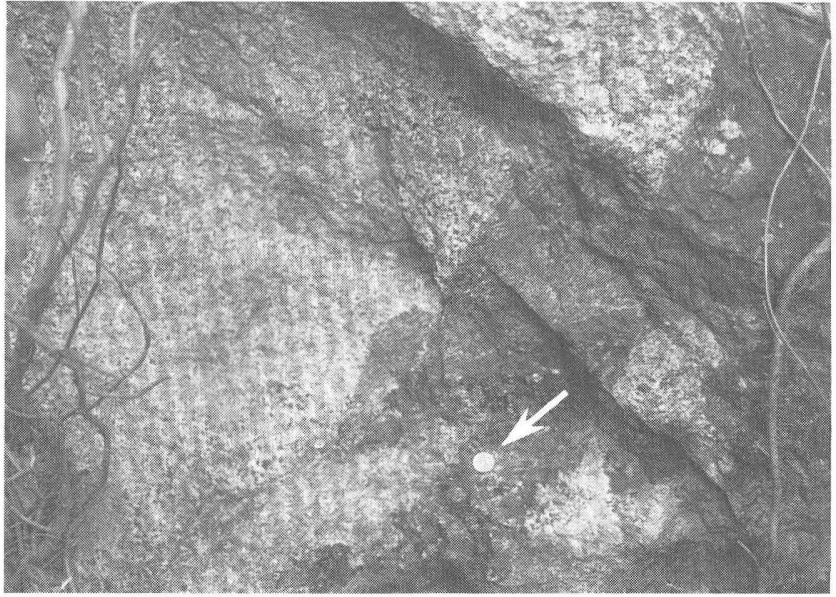

A

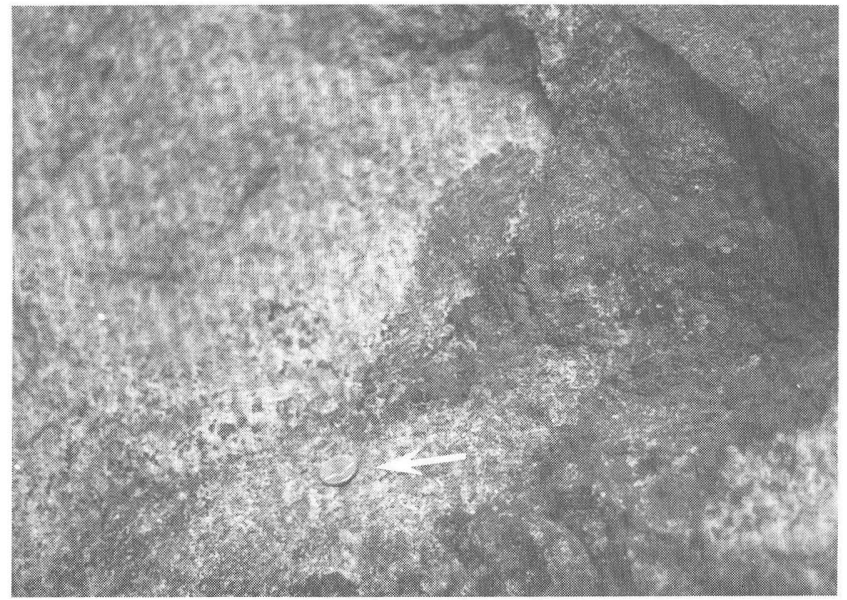

B

Figure C7. Mount Eve Granite intruding amphibolite in quarry in saddle between Mounts Adam and Eve. A, More distant view. Coin is 0.75 inch in diameter. $B$, Close up. Granite cuts across the foliation in the amphibolite at a $90^{\circ}$ angle. Coin is 0.75 inch in diameter. 


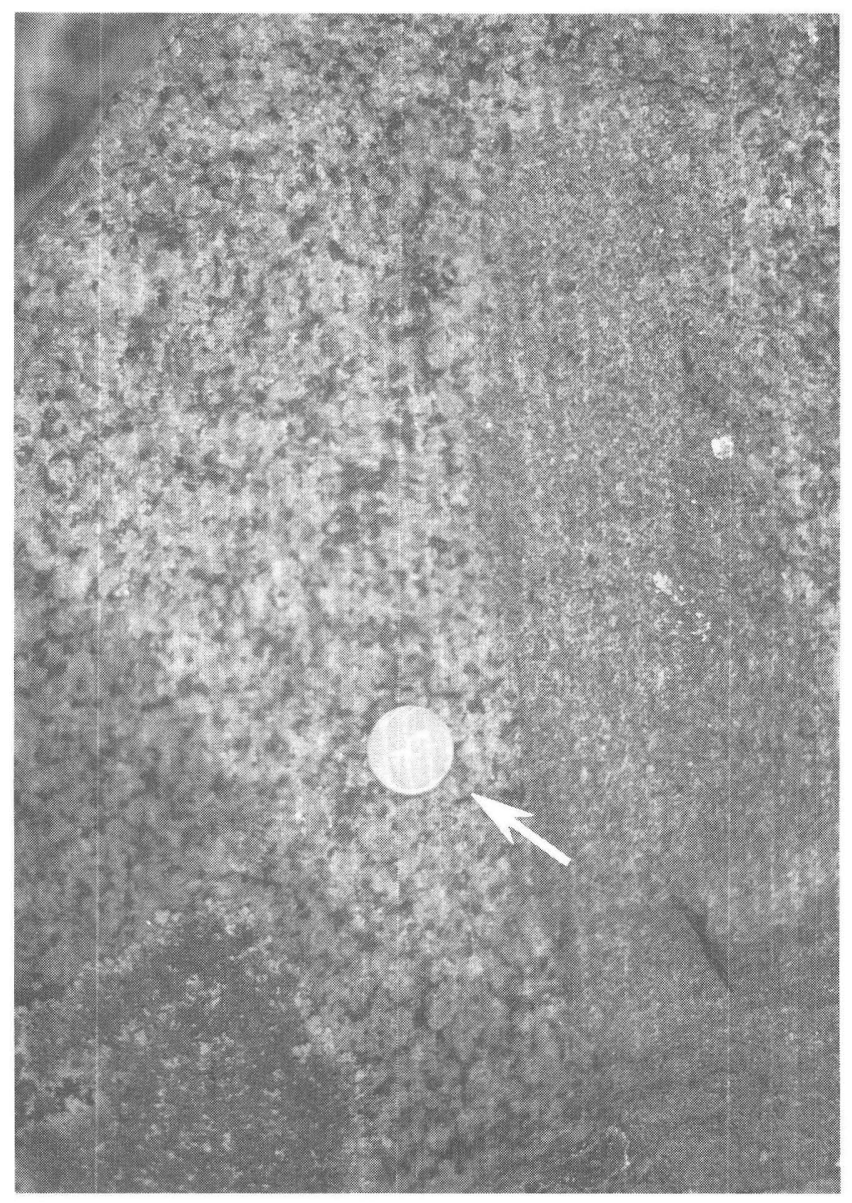

Figure C8. Lenticular inclusion of potassic feldspar gneiss in Mount Eve Granite in quarry in saddle between Mounts Adam and Eve (loc. A in fig. C3). Coin is 0.75 inch in diameter.

Chemical methods for elemental extractions were modified from Krogh (1973). All isotopic ratios were measured on an automated, single collector, VG MicroMass 54E mass spectrometer, with Daly multiplier. Laboratory blank lead ranged from about 0.2 to $1 \mathrm{ng}$ (nanogram), depending on sample size. Ages and concordia systematics were calculated using programs of Ludwig (1980, 1988).

Uranium concentrations are relatively low, ranging from about 170 to $275 \mathrm{ppm}$ (parts per million). The seven analyzed fractions form a linear array that is slightly discordant on a concordia plot (fig. C11), with an upper intercept age of $1034 \pm 13 \mathrm{Ma}$ and a lower intercept age of $671 \pm 110 \mathrm{Ma}$. However, because overgrowths are observed on many of the zircons, we also calculated a best-fit line through only the abraded fractions whose zircons should not contain any younger rims. This regression has intercept ages of $1020 \pm 4$ and $280 \pm 190 \mathrm{Ma}$. We interpret these results to indicate that the Mount Eve Granite crystallized at

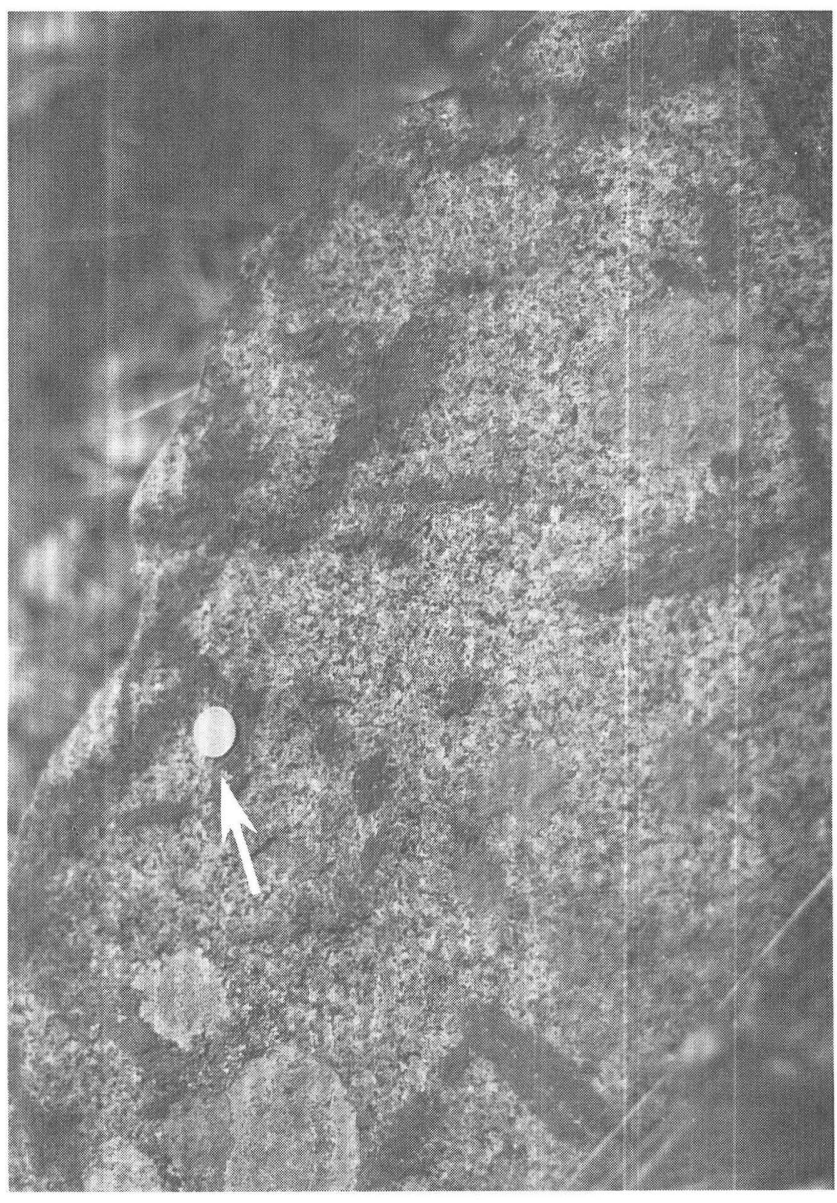

Figure C9. Inclusions of amphibolite in Mount Eve Granite in quarry in saddle between Mounts Adam and Eve (loc. A in fig. C4). Inclusions have a slight preferred orientation, probably resulting from flow alignment. Coin is 0.75 inch in diameter.

about $1020 \mathrm{Ma}$. The lower intercept age is suggestive of Alleghanian disturbance and lead loss, but the uncertainty is large enough to include most possible events during the Phanerozoic.

Fine, unabraded fractions are more discordant than the fractions composed of cores, and they plot to the left of the discordia shown in figure $\mathrm{C} 11$, suggesting formation of overgrowths probably during the Late Proterozoic (Avalonian?). Modern lead loss slightly rotated the discordia for the composite grains, resulting in an upper intercept age that is somewhat too old.

\section{CONCLUSIONS}

Igneous rocks in the New Jersey Highlands can be characterized as being prekinematic, synkinematic, and postkinematic as they relate to the Grenvillian orogenic event. The Losee Metamorphic Suite and the charnockitic 
Table C1. Chemical analyses and CIPW norms of Mount Eve Granite ${ }^{1}$

[In weight percent. Dashes indicate not present.]

\begin{tabular}{|c|c|c|c|}
\hline & 1 & 2 & 3 \\
\hline \multicolumn{4}{|c|}{ Chemical analyses } \\
\hline $\mathrm{SiO}_{2}$ & 66.9 & 71.4 & 73.1 \\
\hline $\mathrm{Al}_{2} \mathrm{O}_{3}$ & 13.9 & 14.3 & 14.6 \\
\hline $\mathrm{Fe}_{2} \mathrm{O}_{3}$ & 1.6 & 1.71 & 1.4 \\
\hline $\mathrm{FeO}$ & 3.0 & .88 & .4 \\
\hline $\mathrm{MgO}$ & .74 & .31 & .16 \\
\hline $\mathrm{CaO}$ & 2.4 & .77 & 1.5 \\
\hline $\mathrm{Na}_{2} \mathrm{O}$ & 3.4 & 3.19 & 4.8 \\
\hline $\mathrm{K}_{2} \mathrm{O}$ & 5.3 & 5.8 & 3.0 \\
\hline $\mathrm{H}_{2} \mathrm{O}^{+}$ & .56 & .53 & .46 \\
\hline $\mathrm{H}_{2} \mathrm{O}^{-}$ & .15 & .12 & .05 \\
\hline $\mathrm{TiO}_{2}$ & .74 & .32 & .11 \\
\hline $\mathrm{P}_{2} \mathrm{O}_{5}$ & .18 & .05 & .03 \\
\hline $\mathrm{MnO}$ & .10 & .02 & .02 \\
\hline $\mathrm{CO}_{2}$ & .02 & .01 & .01 \\
\hline Total & 98.99 & 99.41 & 99.64 \\
\hline \multicolumn{4}{|c|}{ CIPW norms } \\
\hline Quartz & 20.9 & 29.0 & 31.1 \\
\hline Orthoclase & 31.7 & 35.0 & 17.8 \\
\hline Albite & 29.3 & 27.2 & 40.4 \\
\hline Anorthite & 7.2 & 3.1 & 7.5 \\
\hline Corundum & - & 1.6 & .8 \\
\hline Diopside & 3.3 & .8 & .4 \\
\hline Hypersthene & 3.3 & - & - \\
\hline Magnetite & 2.3 & 2.1 & 1.2 \\
\hline Ilmenite & 1.5 & .6 & .2 \\
\hline Apatite & .3 & .3 & - \\
\hline Hematite & - & .3 & .6 \\
\hline Total & 99.8 & 100.0 & $\overline{100.0}$ \\
\hline
\end{tabular}

${ }^{1}$ Descriptions and locations of rocks are as follows:

1. Mt. Eve Granite from abandoned quarry in saddle between Mounts Adam and Eve 200 feet north of the intersection of Little York and Hedges Roads, Pine Island 7.5-minute quadrangle, N.Y.-N.J. (loc. A in fig. C3). Chemically, the rock is granite. This is the same locality as the dated sample. Rapid rock analysis by M. Kavulak, U.S. Geological Survey.

2. Mt. Eve Granite from outcrop on northwest slope of Pochuck Mountain about 200 feet northeast of intersection of Liberty Corners Road and an unnamed northwest-trending road about 1 mile southwest of Owens, Unionville 7.5-minute quadrangle, N.Y.-N.J. (loc. B in fig. C3). Chemically, the rock is granite. Rapid rock analysis by J. Taggart, A. Bartel, and D. Siems, U.S. Geological Survey.

3. Granitoid from outcrop at sharp bend in unnumbered road about 1.4 miles S. $5^{\circ} \mathrm{W}$. from Sparta, N.J., Newton East 7.5-minute quadrangle, N.J. (loc. A in fig. C4). Chemically, the rock is trondhjemite. Rapid rock analysis by H. Smith, U.S. Geological Survey.

sequence constitute the prekinematic sequence. They have been interpreted, on the basis of map relations, to be unconformably beneath the calcareous and quartzofeldspathic sequences. Recently, an unconformable contact between charnockite and an overlying feldspathic quartzite layer in potassic feldspar gneiss has been found, confirming

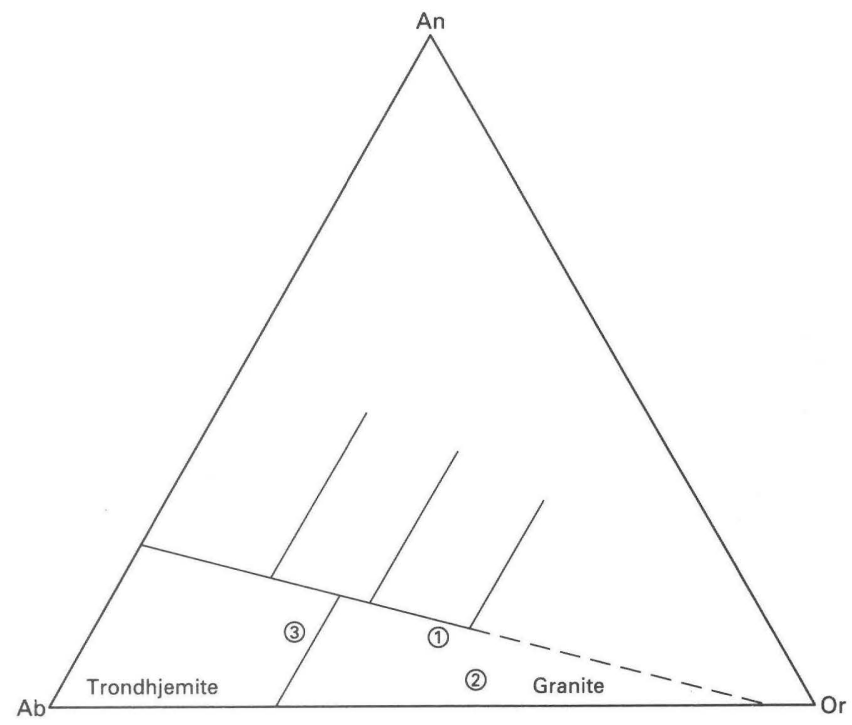

Figure C10. Normative feldspar plot (O'Connor, 1965) of Mount Eve Granite. Sample 1 is from the Mount Eve quarry, sample 2 is from Pochuck Mountain, and sample 3 is from south of Sparta, N.J. (loc. A in fig. C4).

the earlier interpretation. These rocks have not yet been dated.

The synkinematic rocks include the Byram and Lake Hopatcong Intrusive Suites, which were emplaced during the major episode of orogenesis. The Byram has an upper intercept $\mathrm{U}-\mathrm{Pb}$ age of about $1090 \mathrm{Ma}$ (Drake and others, chap. D, this vol.).

Evidence presented herein shows that the Mount Eve Granite is not deformed, and thereby is a posttectonic intrusion. It seems to have the general characteristics of Pitcher's (1982) Caledonian I-type granite, although we noted only metasedimentary xenoliths. This type of granite characteristically is emplaced during postcollision uplift. The Mount Eve Granite is postkinematic, and we place an upper bound for Grenvillian orogenesis in this part of the Reading Prong at $1020 \pm 4 \mathrm{Ma}$.

The lower intercept age (fig. C11) is $671 \pm 110 \mathrm{Ma}$, suggesting an episode of lead loss corresponding to the time of the Avalonian event in eastern Connecticut and Rhode Island, where plagioclase gneisses and granites have been dated at about 620-600 Ma (Wintsch and Aleinikoff, 1987; Zartman and others, 1988). Farther west, in southern New York, using the Rb-Sr whole-rock method, Long (1969) determined an age of $563 \pm 30 \mathrm{Ma}$ for the Yonkers Gneiss (age recalculated using ${ }_{87}=1.42 \times 10^{-11} \mathrm{yr}^{-1}$ ) and Mose and Hayes (1975) dated the Pound Ridge Gneiss at 583 \pm 19 $\mathrm{Ma}$. A similar U-Pb lower intercept age has been found for the Storm King Granite (Aleinikoff, unpub. results, 1986). Thus, although evidence for an Avalonian disturbance is not pervasive throughout the Reading Prong and Hudson Highlands, some isotopic results suggest its occurrence in the area. 
Table C2. Uranium-lead concentration and isotopic compositien data from zircon from the Mount Eve Granite [mg, milligram; ppm, parts per million;]

\begin{tabular}{|c|c|c|c|c|c|c|c|c|c|c|c|c|}
\hline \multirow{3}{*}{ Fraction $^{1}$} & \multirow[t]{3}{*}{$\begin{array}{l}\text { Weight } \\
\text { (mg) }\end{array}$} & \multicolumn{2}{|c|}{$\begin{array}{l}\text { Concentration } \\
(\mathrm{ppm})\end{array}$} & \multicolumn{3}{|c|}{$\mathrm{Pb}$ composition ${ }^{2}$} & \multicolumn{3}{|c|}{ Ratios $^{3}$} & \multicolumn{3}{|c|}{ Ages $(\mathrm{Ma})^{4}$} \\
\hline & & $U$ & $\mathrm{~Pb}$ & ${ }^{206} \mathrm{~Pb}$ & ${ }^{206} \mathrm{~Pb}$ & ${ }^{206} \mathrm{~Pb}$ & ${ }^{206} \mathrm{~Pb}$ & ${ }^{207} \mathrm{~Pb}$ & ${ }^{207} \mathrm{~Pb}$ & ${ }^{206} \mathrm{~Pb}$ & ${ }^{207} \mathrm{~Pb}$ & ${ }^{207} \mathrm{~Pb}$ \\
\hline & & & & ${ }^{204} \mathrm{~Pb}$ & ${ }^{207} \mathrm{~Pb}$ & ${ }^{208} \mathrm{~Pb}$ & ${ }^{238} \mathrm{U}$ & ${ }^{235} \mathrm{U}$ & ${ }^{206} \mathrm{~Pb}$ & ${ }^{238} U$ & ${ }^{235} \mathrm{U}$ & ${ }^{206} \mathrm{~Pb}$ \\
\hline$(+100)$ NMDEA & 0.27 & 172.4 & 28.40 & 114320 & 13.660 & 15.601 & $.1684(.48)$ & $1.696(.49)$ & $.0731(.08)$ & 1003 & 1007 & 1016 \\
\hline$(-100+150)$ NMDEA & 0.84 & 168.9 & 28.05 & 11107 & 13.436 & 16.423 & $.1698(.47)$ & $1.713(.47)$ & $.0731(.06)$ & 1011 & 1013 & 1018 \\
\hline$(-150+200) \mathrm{NMD}$ & 6.64 & 238.6 & 39.35 & 2514.4 & 12.722 & 16.978 & $.1674(.55)$ & $1.683(.56)$ & $.0729(.06)$ & 998 & 1002 & 1012 \\
\hline$(-150+200) \mathrm{NMDA}$ & 0.58 & 266.8 & 42.98 & 9450.2 & 13.414 & 23.653 & $.1675(.46)$ & $1.687(.47)$ & $.0730(.06)$ & 998 & 1004 & 1015 \\
\hline$(-200+250) \mathrm{NMD}$ & 2.02 & 264.0 & 42.33 & 12684 & 13.527 & 21.768 & $.1663(.47)$ & $1.670(.48)$ & $.0728(.11)$ & 992 & 997 & 1008 \\
\hline$(-325+400) \mathrm{NMD}$ & 3.05 & 274.7 & 43.79 & 15862 & 13.596 & 20.980 & $.1652(.47)$ & $1.655(.47)$ & $.0727(.06)$ & 985 & 991 & 1004 \\
\hline$(-400)$ NMD & 1.26 & 266.5 & 42.88 & 4225.7 & 13.180 & 17.698 & $.1645(.79)$ & $1.645(.80)$ & $.0725(.10)$ & 982 & 987 & 1000 \\
\hline
\end{tabular}

\footnotetext{
${ }^{1}$ Abbreviations: NM, nonmagnetic; D, diamagnetic; E, elongate; A, abraded.

${ }^{2} \mathrm{~Pb}$ composition ratios corrected from $0.14 \pm .05 \%$ /average mass unit mass fractionation and 1 nanogram or less blank $\mathrm{Pb}$ of composition $1: 18.8: 15.7: 38.5$.

${ }^{3} 2$ sigma errors (expressed as a percent) in parentheses.

${ }^{4}$ Ages corrected for common lead using appropriate values from Stacey and Kramers (1975).

Constants: ${ }^{235} \mathrm{U}=9.8485 \mathrm{E}-10 / \mathrm{yr} ;{ }^{238} \mathrm{U}=1.55125 \mathrm{E}-10 / \mathrm{yr} ;{ }^{238} \mathrm{U} /{ }^{235} \mathrm{U}=137.88$ (Steiger and, Jäger 1977).
}



Figure C11. Concordia diagram for zircons from the Mount Eve Granite. MSWD, mean square of the weighted deviations (from the mean). 


\section{REFERENCES CITED}

Drake, A.A., Jr., 1984, The Reading Prong of New Jersey and eastern Pennsylvania: An appraisal of rock relations and chemistry of a major Proterozoic terrane in the Appalachians, in Bartholomew, M.J., ed., The Grenville event in the Appalachians and related topics: Geological Society of America Special Paper 194, p. 75-109.

Drake, A.A., Jr., Kastelic, R.L., Jr., and Lyttle, P.T., 1985 , Geologic map of the eastern parts of the Belvidere and Portland quadrangles, Warren County, New Jersey: U.S. Geological Survey Miscellaneous Investigations Map I-1530, scale 1:24,000.

Grauch, R.I., and Ludwig, K.R., 1980, Precambrian uranium mineralization in the central Appalachians: Geological Society of America Abstracts with Programs, v. 12, p. 39.

Hague, J.M., Baum, J.L., Herrman, L.A., and Pickering, R.J., 1956, Geology and structure of the Franklin-Sterling area, New Jersey: Geological Society of America Bulletin, v. 67 , p. 434-474.

Kemp, J.F., and Hollick, Arthur, 1894, The granite at Mounts Adam and Eve, Warwick, Orange County, N.Y., and its contact phenomena: New York Academy of Science Annals, v. 7, p. 638-654.

Krogh, T.E., 1973, A low-contamination method for hydrothermal decomposition of zircon and extraction of $\mathrm{U}$ and $\mathrm{Pb}$ for isotopic age determination: Geochimica et Cosmochimica Acta, v. 37, p. 485-494.

Long, L.E., 1969, Whole-rock Rb-Sr age of the Yonkers Gneiss, Manhattan Prong: Geological Society of America Bulletin, v. 80 , p. 2087-2090.

Ludwig, K.R., 1980, Calculation of uncertainties of U-Pb isotopic data: Earth and Planetary Science Letters, v. 46, p. 212-220.

1988, ISOPLOT VERSION 2-A plotting and regression program for isotope geochemists, for use with HP Series 200/300 computers: U.S. Geological Survey Open-File Report 87-601, 59 p.

Mather, W.W., 1843, Geology of New York, Part 1, Comprising the geology of the first geological district: Albany, New York Geological Survey, $653 \mathrm{p}$.
Mose, D.G., and Hayes, John, 1975, Avalonian igneous activity in the Manhattan Prong, southeastern New York: Geological Society of America Bulletin, v. 86, p. 929-932.

O'Connor, J.T., 1965, A classification for quartz-rich igneous rocks based on feldspar ratios: U.S. Geological Survey Professional Paper 525-B, p. B79-B84.

Offield, T.W., 1967, Bedrock geology of the Goshen-Greenwood Lake area, New York: New York State Museum and Science Service Map and Chart Series 9, 78 p.

Pitcher, W.S., 1982, Granite type and tectonic environment, in Hsu, K.J., ed., Mountain building processes: New York, Academic Press, p. 19-40.

Ries, Heinrich, 1895, Geology of Orange County: New York State Museum Annual Report 49, pt. 2, p. 393-475.

Spencer, A.C., Kummel, H.B., Wolff, J.E., Salisbury, R.D., and Palache, Charles, 1908, Franklin Furnace, New Jersey: U.S. Geological Survey Geologic Atlas of the United States, Folio 161, 27 p., 6 maps.

Stacey, J.S., and Kramers, J.D., 1975, Approximation of terrestrial lead isotope evolution by a two-stage model: Earth and Planetary Science Letters, v. 26, p. 207-226.

Steiger, R.H., and Jäger, Emile, 1977, Subcommission on geochronology, Convention on the use of decay constants in geo- and cosmochronology: Earth and Planetary Science Letters, v. 36, p. 359-362.

Streckeisen, Albert, 1976, To each plutonic rock its proper name: Earth Science Reviews, v. 12, p. 1-33.

Volkert, R.A., and Drake, A.A., Jr., 1986, Some Middle Proterozoic rocks of the New Jersey Highlands, in Husch, J.M., and Goldstein, F.R., eds., Geology of the New Jersey Highlands and radon in New Jersey: Geological Association of New Jersey annual meeting, 3d, Randolph, N.J., Field guide and proceedings, p. 1-17.

Wintsch, R.P., and Aleinikoff, J.N., 1987, U-Pb isotopic and geologic evidence for late Paleozoic anatexis, deformation, and accretion of the Late Proterozoic Avalon terrane, southcentral Connecticut: American Journal of Science, v. 287, p. $107-126$.

Zartman, R.H., Hermes, O.D., and Pease, M.H., Jr., 1988, Zircon crystallization ages, and subsequent isotopic disturbance events, in gneissic rocks of eastern Connecticut and western Rhode Island: American Journal of Science, v. 288, p. $376-402$. 
Chapter D

The Byram Intrusive Suite of the Reading ProngAge and Tectonic Environment

By AVERY ALA DRAKE, JR., and JOHN N. ALEINIKOFF, U.S. Geological Survey, and RICHARD A. VOLKERT, New Jersey Geological Survey 


\title{
CONTENTS
}

\author{
Abstract D1 \\ Introduction D1 \\ Regional Geology D1 \\ Byram Intrusive Suite D4 \\ Petrography and Field Relations D4 \\ Chemistry D4 \\ U-Pb Geochronology D5 \\ Storm King Granite D6 \\ Petrography and Field Relations D6 \\ Chemistry D10 \\ Tectonic Environment D11 \\ Conclusions D11 \\ References Cited D13
}

\section{FIGURES}

D1-D3. Maps showing:

D1. Distribution of rocks older than 1 billion years in Eastern North America D2

D2. Highly generalized geologic map of the Durham and Reading Hills, New Jersey Highlands, and part of the Hudson Highlands D3

D3. Distribution of Middle Proterozoic rocks of the Reading Prong in New Jersey and immediately adjacent New York D5

D4. Modal Q-A-P plot of rocks of the Byram Intrusive Suite from the Durham and Reading Hills and the New Jersey Highlands D6

D5. Geologic map of part of the Greenwood Lake quadrangle, New York-New Jersey D7

D6. Modal Q-A-P plot of rocks of the Byram Intrusive Suite in the Greenwood Lake quadrangle, New York-New Jersey D8

D7. Normative An-Ab-Or plot comparing rocks of the Byram Intrusive Suite with rocks of the Storm King Granite D8

D8. Graph of Shand's index showing different tectonic environments of granitoids D8

D9. $\mathrm{Na}_{2} \mathrm{O}-\mathrm{K}_{2} \mathrm{O}$ plot of rocks of the Byram Intrusive Suite and Storm King Granite D9

D10. Graph of oxidation ratio vs. differentiation index of rocks of the Byram Intrusive Suite and Storm King Granite D9

D11. $\mathrm{TiO}_{2}-\mathrm{FeO}-\mathrm{Fe}_{2} \mathrm{O}_{3}$ diagram for rocks of the Byram Intrusive Suite and Storm King Granite showing their oxidation state D9

D12. Normative Q-Ab-Or plot of rocks of the Byram Intrusive Suite and Storm King Granite showing water pressures of $0.5,2$, and 5 kilobars D9

D13. Plot of rocks of the Byram Intrusive Suite and Storm King Granite on the Or-Ab-An- $\mathrm{SiO}_{2}$ system at 5 kilobars $\mathrm{P}_{\mathrm{H}_{2} \mathrm{O}} \quad$ D10

D14. Concordia plot of U-Pb data from zircons from sample NY/GL 1-82 D10 
D15. Generalized geologic map of the Bear Mountain area, New York D12

D16. Modal Q-A-P plot of hornblende granite from the Hudson Highlands D13

\section{TABLES}

D1. Molar $\mathrm{Al}_{2} \mathrm{O}_{3} /\left(\mathrm{CaO}+\mathrm{Na}_{2} \mathrm{O}+\mathrm{K}_{2} \mathrm{O}\right)$ ratios of rocks of the Byram Intrusive Suite and Storm King Granite D8

$\mathrm{D} 2$. U-Pb isotopic data from zircons from hornblende granite of the Byram Intrusive Suite D11 


\title{
The Byram Intrusive Suite of the Reading Prong- Age and Tectonic Environment
}

\author{
By Avery Ala Drake, Jr., John N. Aleinikoff, and Richard A. Volkert
}

\begin{abstract}
Rocks of the Byram Intrusive Suite are the most abundant granitoid rocks in the Reading Prong of New Jersey and eastern Pennsylvania. The Storm King Granite in the Hudson Highlands to the east is similar to the Byram both petrographically and petrochemically, and the two units have been correlated by almost all geologists. Both units are I-type granitoids, belong to the magnetite-series of granitoids, are interpreted to have been generated in a continental arc setting, and were synkinematically emplaced during the Grenville orogeny.

Zircons from the Byram were difficult to date because of both an inherited component and later overgrowths. The time of emplacement of the Byram is best interpreted to be about $1090 \mathrm{Ma}$. The Storm King has a time of emplacement of about $1134 \mathrm{Ma}$. Taken at face value, this suggests that granite emplacement occurred over a period of about $44 \mathrm{~m} . \mathrm{y}$. , not an unreasonable interpretation based on younger continental arc magma systems. In any case, the isotopic ages of these rocks suggest that the Grenville orogeny spanned the period $1134 \mathrm{Ma}$ to $1020 \mathrm{Ma}$, when the postkinematic Mount Eve Granite was emplaced.
\end{abstract}

\section{INTRODUCTION}

Granitoid rocks of the Byram Intrusive Suite are the most abundant intrusive rocks within the Durham and Reading Hills (Drake, in press a) and New Jersey Highlands (Drake, 1990) segments of the Reading Prong (fig. D1), a major external massif in the central Appalachians (Drake and others, 1988). Similar rocks crop out in the Hudson Highlands and were called Storm King Granite by Berkey (1907) and described in detail by Lowe (1950). Most geologists have correlated the Byram and Storm King because of their petrographic and chemical similarity. Recent U-Pb dating, however, suggests that the Storm King Granite has an age of about 1134 Ma (J.N. Aleinikoff, unpub. data) and the Byram an age of about $1090 \mathrm{Ma}$. In this paper we briefly discuss the petrography and petro-

Manuscript approved for publication July 19, 1990. chemistry of the Byram Intrusive Suite and Storm King Granite, present the geochronological data for the Byram, interpret the tectonic environment within which the granitoids were emplaced, and attempt to explain the age dichotomy.

\section{REGIONAL GEOLOGY}

The Reading Prong is underlain by roughly equal parts of metavolcanic, metasedimentary, and granitoid intrusive rocks (fig. D2). The oldest of these rocks in Pennsylvania is the Hexenkopf Complex (Drake, 1984, in press a), a sequence of severely metamorphosed and altered mafic diorite, gabbro, pyroxenite, and impure chert that is interpreted to be an oceanic suite. The Hexenkopf Complex is unconformably overlain by the Losee Metamorphic Suite, a major rock unit in New Jersey and New York (fig. D2), where it is associated with rocks of charnockitic aspect. The Losee is interpreted to be a metamorphosed sequence of quartz keratophyre, dacite, and basalt, and related trondhjemite and tonalite intrusions (Drake, 1984, 1990, in press a). Many of the charnockitic rocks are interpreted to result from the high-grade metamorphism and anatexis of the Losee. Others are probably enderbite and quartz-poor enderbite intrusions (Drake, 1990).

The Losee and charnockitic rocks are unconformably overlain by a sequence of marble, other calcareous rocks, and abundant quartzofeldspathic gneisses. Much of the quartzofeldspathic sequence is potassic feldspar gneiss that at places contains abundant magnetite, suggesting that it may be metamorphosed iron-formation, perhaps with an exhalitive component (Drake, 1984, 1990, in press a).

All these rocks are intruded by large to small synkinematic sheets of the Byram Intrusive Suite (Drake, 1984), Storm King Granite (Lowe, 1950), and the Lake Hopatcong Intrusive Suite (Drake and Volkert, chap. A, this vol.). The Lake Hopatcong differs from the Byram and Storm King in that it is characterized by clinopyroxene and microantiperthite, whereas the other rocks are characterized by hornblende and microperthite. The Lake Hopatcong Intrusive Suite is not considered further herein. 


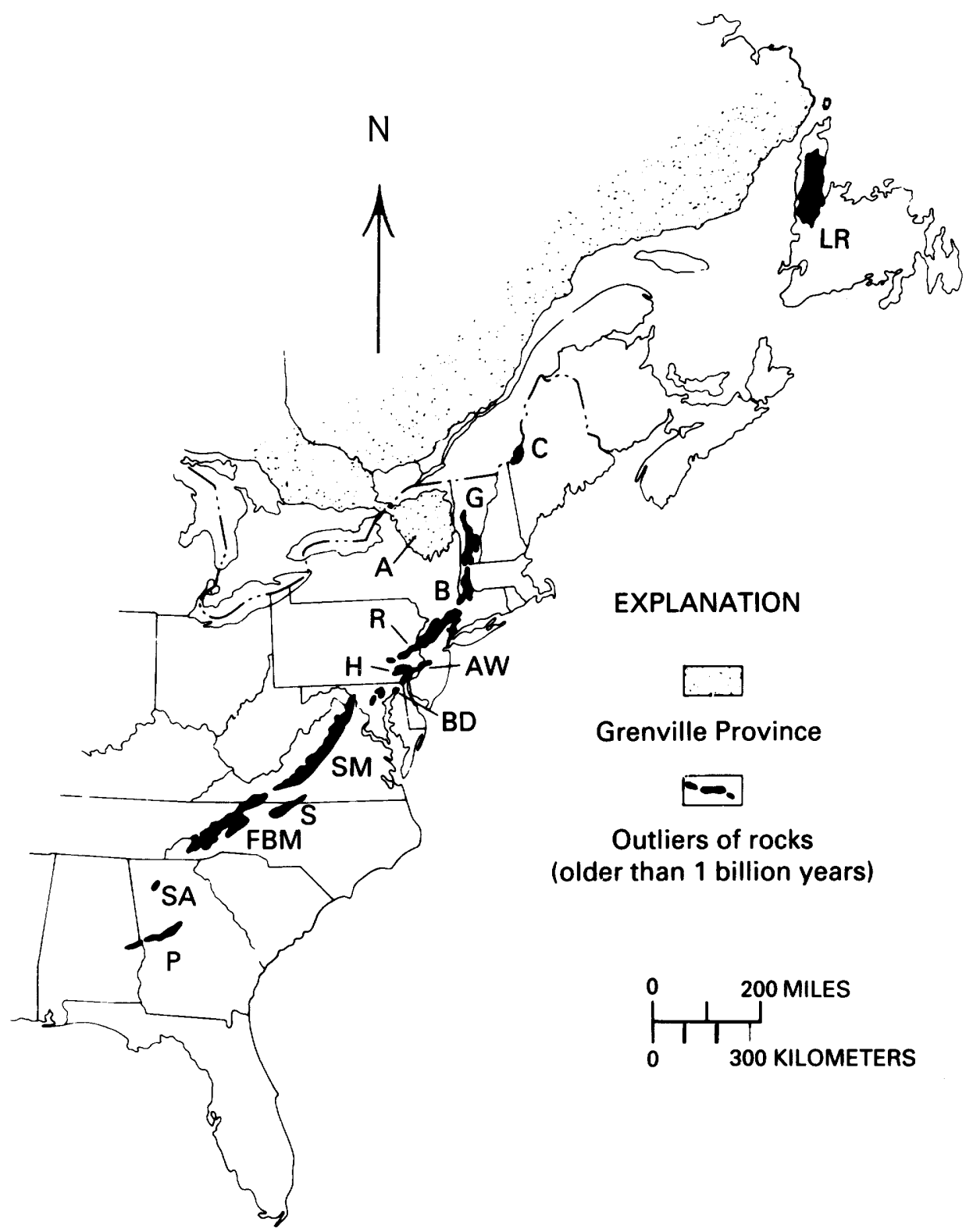

Figure D1. Distribution of rocks older than 1 billion years in Eastern North America. LR, Long Range; C, Chain Lakes massif; G, Green Mountain massif; A, Adirondack massif; B, Berkshire massif; R, Reading Prong; H, Honey Brook upland; AW, Avondale-West Chester massif; BD, Baltimore "gneiss domes"; SM, Shenandoah massif; S, Sauratown Mountains window; FBM, French Broad massif; SA, Salem Church anticline; and P, Pine Mountain window. Modified from Drake (1984).

The metavolcanic and metasedimentary rocks are also intruded by small bodies of Mount Eve Granite in a small area of northern New Jersey and immediately adjacent New York (Drake and others, chap. C, this vol.). The Mount Eve appears to be postkinematic. It has an upper intercept $\mathrm{U}-\mathrm{Pb}$ age of $1020 \pm 4 \mathrm{Ma}$, which can be taken as the upper bound for the Grenville orogeny in the New Jersey and Hudson Highlands (Drake and others, 1990, chap. C, this vol.).
Three phases of folds have been mapped in the Durham and Reading Hills (Drake, in press b) and New Jersey Highlands (Drake and others, 1985). These folds deform compositional layering and foliation that is marked by hornblende and feldspar crystals, as well as lens-shaped rock bodies that probably result from regional transposition. None of these mapped phases are first folds. The only evidence for earlier deformation is provided by the foliation 


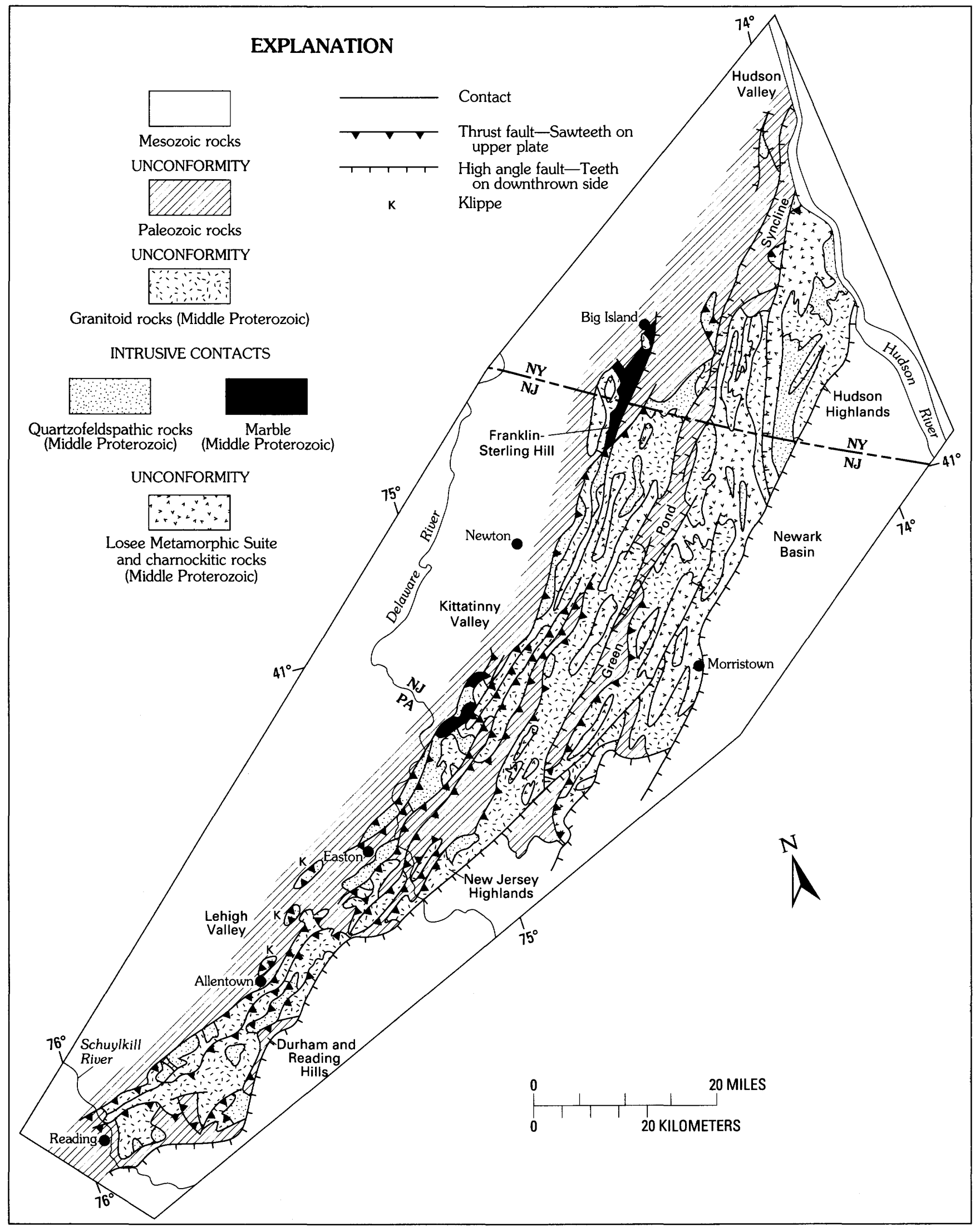

Figure D2. Highly generalized geologic map of the Durham and Reading Hills, New Jersey Highlands, and part of the Hudson Highlands. Modified from Rankin, Drake, and Ratcliffe (1989). 
and the regional transposition. The rocks of the Byram and Lake Hopatcong Intrusive Suites were emplaced synkinematically during the event, resulting in the oldest mapped folds. The Mount Eve Granite was emplaced after the youngest folds.

Three fold phases are also recognized in the Hudson Highlands (Helenek, 1971; Dallmeyer, 1972; Ratcliffe and others, 1972; Helenek and Mose, 1984). The Storm King Granite was emplaced during the second of these phases (Ratcliffe, in Rankin and others, in press). The second mapped folds in the Hudson Highlands, therefore, correlate with the first mapped folds in the New Jersey Highlands and Durham and Reading Hills.

\section{BYRAM INTRUSIVE SUITE}

Rocks of the Byram Intrusive Suite are the most abundant of the Middle Proterozoic units in Pennsylvania (Drake, in press a) and western New Jersey. In central New Jersey, rocks of the Lake Hopatcong Intrusive Suite occur in subequal amounts with the Byram (Drake and Volkert, chap. A, this vol.). Many of the Lake Hopatcong rocks were mismapped as Byram by earlier workers. The Lake Hopatcong Intrusive Suite has not been recognized in southeastern New York.

\section{Petrography and Field Relations}

The Byram Intrusive Suite rocks are medium- to coarse-grained, pink to buff to bronze, gneissoid to indistinctly foliated granitoids and sparse granite gneiss. They consist largely of quartz, microperthite, and oligoclase. The Byram consists of five different rock types: hornblende granite, microperthite alaskite, hornblende-quartz syenite, hornblende syenite, and biotite granite. The hornblende granite differs from the alaskite in its content of hornblende (ferrohastingsite), and both differ from the syenites in their quartz contents. The quartz-poor rocks are most common in the Washington, Tranquility, and Stanhope quadrangles (fig. D3). Biotite granite occurs in sparse amounts and is interpreted to have resulted from the assimilation and modification of biotite-bearing metasedimentary rocks by alaskite (Drake, 1969, 1984; Sims, 1958). All phases of the Byram contain some magnetite, as much as 4 percent in some specimens, as well as accessory zircon, apatite, and sphene.

Abundant modal data are available for rocks of the Byram Intrusive Suite in New Jersey west of the Franklin and Dover quadrangles (fig. D3) and in eastern Pennsylvania (fig. D4). The bulk of the rocks are either syenogranites or monzogranites that plot near the field boundary. Quartz syenite and syenite are underrepresented, because so few of these rocks have been point counted. Recent work north of the Wisconsinan terminal moraine, where more rocks are exposed, shows that the interior parts of the intrusive sheets are alkali-feldspar granite, suggesting that these rocks may be a late differentiate.

Migmatitic rocks have been recognized and described in western New Jersey and eastern Pennsylvania by Buckwalter (1962) and Drake and others (1961), but strangely. have not been recognized east of the Belvidere quadrangle (fig. D3). Perhaps the migmatizing process has gone to completion in this area.

To compare the rocks along the New Jersey-New York boundary with those from the better studied western area, modes of rocks from the Greenwood Lake quadrangle (figs. D3, D5) were plotted separately from those to the west (fig. D6). These modes have about the same distribution as those in figure D4, except that no syenites were recognized and there are proportionally fewer monzogranites and alkali feldspar granites. The dated sample (" $x$ " in fig. D5) is an alkali feldspar granite containing about 57 percent microperthite, 7 percent oligoclase, 31 percent quartz, and 5 percent hornblende.

In most of New Jersey and eastern Pennsylvania, the Byram rocks form small to large, essentially conformable sheets within the hornblende granulite facies country rocks, which range from about $200 \mathrm{ft}$ (feet) to as much as $4 \mathrm{mi}$ (miles) long. The sheet from which the dated sample was taken in the Greenwood Lake quadrangle (fig. D5) appears to be more than $6 \mathrm{mi}$ long, judging from the New York State map (Fisher and others, 1970). How much of this length is real and how much results from the requirements of small-scale compilation is unknown. In any case, the outcrop pattern and the bulbous southern end of the sheet east of Sterling Lake (fig. D5) suggest a refolded fold, and that the mapped synform is a third phase fold.

\section{Chemistry}

The chemistry of rocks from the Byram Intrusive Suite has been published by Baker and Buddington (1970), Drake $(1969,1984)$, Drake and Volkert (chap. A, this vol.), Sims (1958), and Young (1978). This chemistry is summarized in figure D7. Chemically, most of the rocks are granite and some are quartz monzonite. The aberrant trondhjemite and tonalite samples are hybrid rocks. The rocks are calc-alkaline (Drake, 1984; Drake and Volkert, chap. A, this vol.). Most are either mildly peraluminous or mildly metaluminous (fig. D8), but there is some scatter, probably because of the hybrid nature of some rocks. Their molecular ratios of $\mathrm{Al}_{2} \mathrm{O}_{3} /\left(\mathrm{CaO}+\mathrm{Na}_{2} \mathrm{O}+\mathrm{K}_{2} \mathrm{O}\right)$ range from 0.67 to 1.09 , all being less than 1.1 (table D1). Their $\mathrm{Na}_{2} \mathrm{O} / \mathrm{K}_{2} \mathrm{O}$ ratios are greater than 1 (fig. D9), and their oxidation state is high (figs. D10, D11). Almost all the rocks are diopside normative (Drake, 1984; Drake and Volkert, chap. A, this vol.). A Q-Ab-Or plot of the Byram rocks (fig. D12) shows that they tend to cluster at water 


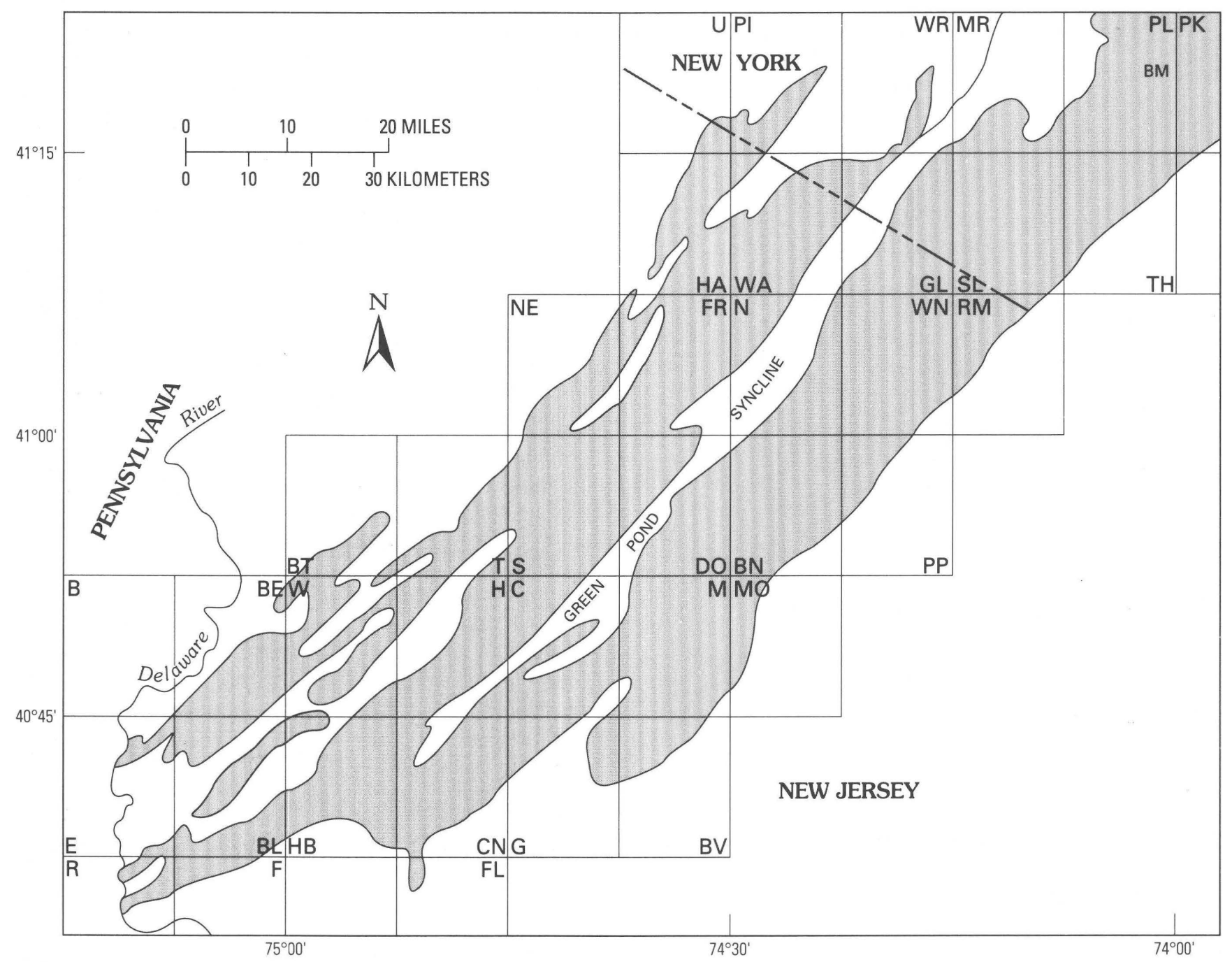

Figure D3. Distribution of Middle Proterozoic rocks of the Reading Prong in New Jersey and immediately adjacent New York. Quadrangles (7.5-minute) are as follows: R, Riegelsville; F, Frenchtown; FL, Flemington; E, Easton; BL, Bloomsbury; HB, High Bridge; CN, Califon; G, Gladstone; BV, Bernardsville; B, Banger; BE, Belvidere; W, Washington; H, Hackettstown; C, Chester; M, Mendham; MO, Morristown; BT, Blairstown; T, Tranquility; S, Stanhope; DO, Dover; BN, Boonton; PP, Pompton Plains; NE, Newton East; FR, Franklin; N, Newfoundland; WN, Wanaque; RM, Ramsey; HA, Hamburg; WA, Wawayanda; GL, Greenwood Lake; SL, Sloatsburg; TH, Thiels; U, Unionville; PI, Pine Island; WR, Warwick; MR, Monroe; PL, Popolopen Lake; and PK, Peekskill. Place mentioned in text: BM, Bear Mountain.

pressures between 2 and $5 \mathrm{~kb}$ (kilobars). A normative An-Ab-Or plot (fig. D13) shows that most of the rocks plot in the low-temperature region of the system and near the orthoclase-oligoclase boundary of the granodiorite system (Tuttle and Bowen, 1958), suggesting that they solidified by fractional crystallization trending from granodioritic to alkali-feldspar granitic composition at temperatures roughly between 650 and $750{ }^{\circ} \mathrm{C}$, assuming the system was water saturated.

All these data suggest that rocks of the Byram Intrusive Suite are I-type granites that were derived from the melting of an igneous source (Chappell and White, 1974). In addition, most can be assigned to the magnetite series of Ishihara (1977).

\section{U-Pb Geochronology}

Zircons from hornblende granite sample NY/GL 1-82 are heterogeneous in morphology. Nearly all the grains are fractured. Many are subhedral and nearly equant; about 10 percent are euhedral, prismatic, and doubly terminated. Within the euhedral population, the grains are medium to dark brown, are finely zoned, and have thin, unzoned, clear overgrowths. About 20 percent of the euhedral zircons have an optically perceptible, rounded core (either clear or dark brown). Because of the variability in color, shape, zoning, and presence or absence of a core, we handpicked several fractions of zircons that appeared to be the least deformed (that is, had both terminations and minimal fractures), as 


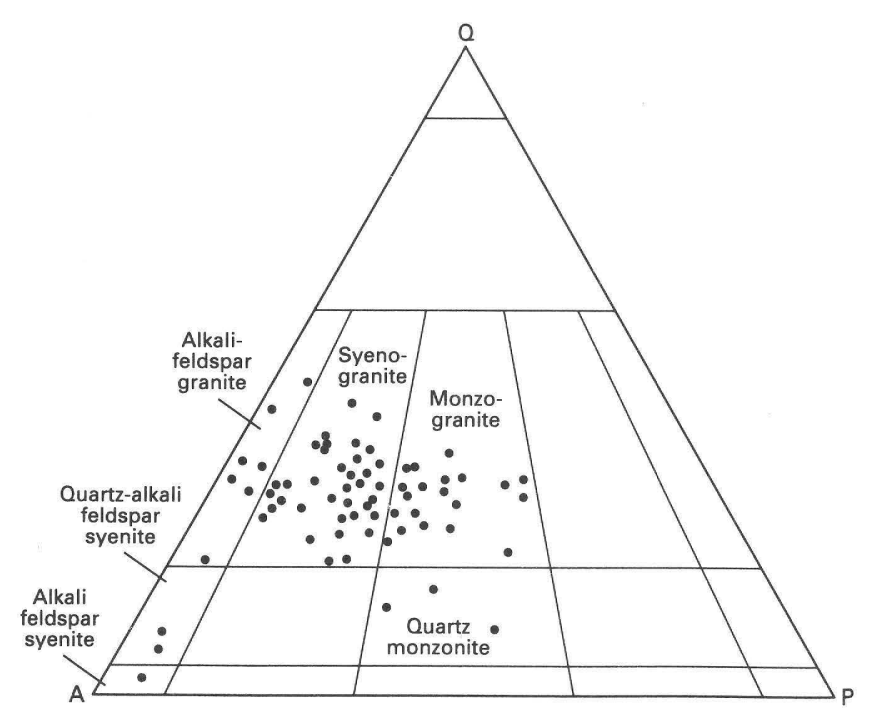

Figure D4. Modal Q-A-P plot of rocks of the Byram Intrusive Suite from the Durham and Reading Hills and the New Jersey Highlands exclusive of the Greenwood Lake quadrangle. Data from Baker and Buddington (1970), Drake (1969), Hague and others (1956), Kastelic (1980), Sims (1958), Smith (1969), and Young (1971).

well as three fractions separated by size and magnetic susceptibility. As discussed below, however, in spite of our attempts to prepare homogeneous splits, this granite has proved to be a formidable rock to date.

Three fractions composed of diamagnetic and nonmagnetic zircons (table D2, fractions 6-8) have ${ }^{207} \mathrm{~Pb} /{ }^{206} \mathrm{~Pb}$ ages ranging from 1031 to $1063 \mathrm{Ma}$. Five fractions composed of handpicked, nonmagnetic, abraded zircons have ${ }^{207} \mathrm{~Pb} /{ }^{206} \mathrm{~Pb}$ ages ranging from 1074 to $1110 \mathrm{Ma}$. Uranium concentrations range from 483 to $673 \mathrm{ppm}$ in the unabraded splits and from 146 to $440 \mathrm{ppm}$ in the abraded splits. As shown in figure D14, the unabraded fractions are more discordant than the fractions of abraded zircon (except fraction 2). A best-fit regression through seven points (fraction 2 excluded) has an upper intercept age of $1122 \pm 53$ $\mathrm{Ma}$ and a large MSWD (mean square of the weighted deviations (from the mean)) (fig. D14).

Based on morphology and isotopic systematics, we suggest that the unabraded zircons contain at least two age components: (1) the bulk of the crystals (euhedrally zoned) and (2) clear overgrowths. Grains with cores may have a third, inherited component. Fractions 6, 7, and 8 plot between these two age components (fig. D14). Four of the five abraded fractions (1, 3, 4, and 5) are between 2 and 4.5 percent discordant. Fraction 4 , with a ${ }^{207} \mathrm{~Pb} /{ }^{206} \mathrm{~Pb}$ age of $1074 \mathrm{Ma}$, probably contained a small amount of rim material, despite abrasion. ${ }^{207} \mathrm{~Pb} /{ }^{206} \mathrm{~Pb}$ ages of fractions 1 , 3 , and 5 probably are representative of the age of intrusion of the granite. A best-fit line calculated for these three fractions and forced through a lower intercept of $0 \pm 50 \mathrm{Ma}$ has an upper intercept age of $1088 \pm 41 \mathrm{Ma}$. The uncertainty is high because of the 8 -m.y. range in ${ }^{207} \mathrm{~Pb} /{ }^{206} \mathrm{~Pb}$ ages and the limited spread in $\mathrm{Pb} / \mathrm{U}$ ages (table D2). Perhaps a better estimate of the age of emplacement, the weighted average of the ${ }^{207} \mathrm{~Pb} /{ }^{206} \mathrm{~Pb}$ age of fractions 1,3 , and 5 , is $1087 \pm 7$ Ma. The weighted average calculation assumes that the isotopic systematics of the cores were disturbed only in the geologic past. With a Paleozoic or Mesozoic Pb-loss event, the ${ }^{207} \mathrm{~Pb} /{ }^{206} \mathrm{~Pb}$ ages become minimum ages. It is likely that the age of granite emplacement is about $1090 \mathrm{Ma}$. Thus, the upper intercept age based on the regression through seven fractions is spurious, the result of multiple times of zircon growth and lead loss.

Fraction 2, with a ${ }^{207} \mathrm{~Pb} /{ }^{206} \mathrm{~Pb}$ age of $1110 \mathrm{Ma}$, probably contained an inherited component. As noted earlier, about 20 percent of the prismatic grains contain cores. We suggest that despite our efforts to pick pristine, single-age-component grains, fraction 2 contained some grains with cores.

The clear overgrowths probably formed after about $1031 \mathrm{Ma}\left({ }^{207} \mathrm{~Pb} /{ }^{206} \mathrm{~Pb}\right.$ age of the $(-400) \mathrm{NM}$ fraction (fraction 8 , table D2)). A likely time of zircon overgrowth may be about $1020 \mathrm{Ma}$, the age of emplacement of the postkinematic Mount Eve Granite (Drake and others, chap. C, this vol.) of northern New Jersey and southeastern New York. Alternatively, the high-grade metamorphism responsible for regional foliation in the Byram Intrusive Suite, which occurred sometime between about 1090 and $1020 \mathrm{Ma}$ (Drake and others, 1990), may have provided fluids and zircon for formation of the thin rims of zircon.

\section{STORM KING GRANITE}

Hornblende granite in the Hudson Highlands was named Storm King Granite by Berkey (1907) for exposures on Storm King Mountain in Putnam and Orange Counties, N.Y., and was mapped as such by Berkey and Rice (1919) and Lowe (1950). That name, however, was not used by Dodd (1965), who mapped in the same area (Popolopen Lake quadrangle, fig. D3) as Lowe, or by Jaffe and Jaffe (1973) in the Monroe quadrangle (fig. D3) immediately to the west. Storm King is not used on the Geologic Map of New York State (Fisher and others, 1970). More recent workers such as Helenek and Mose (1984) and Ratcliffe (in Rankin and others, in press) map the hornblende granite in the Hudson Highlands as Storm King Granite. It is considered herein that the hornblende granite in the Hudson Highlands is Storm King Granite.

\section{Petrography and Field Relations}

The typical Storm King Granite is medium to coarse grained, pink to buff to bronze, and gneissoid to nearly 




Figure D5. Geologic map of part of the Greenwood Lake quadrangle, New York-New Jersey, showing location of dated sample. Modified from Hotz (1953) and Offield (1967). 


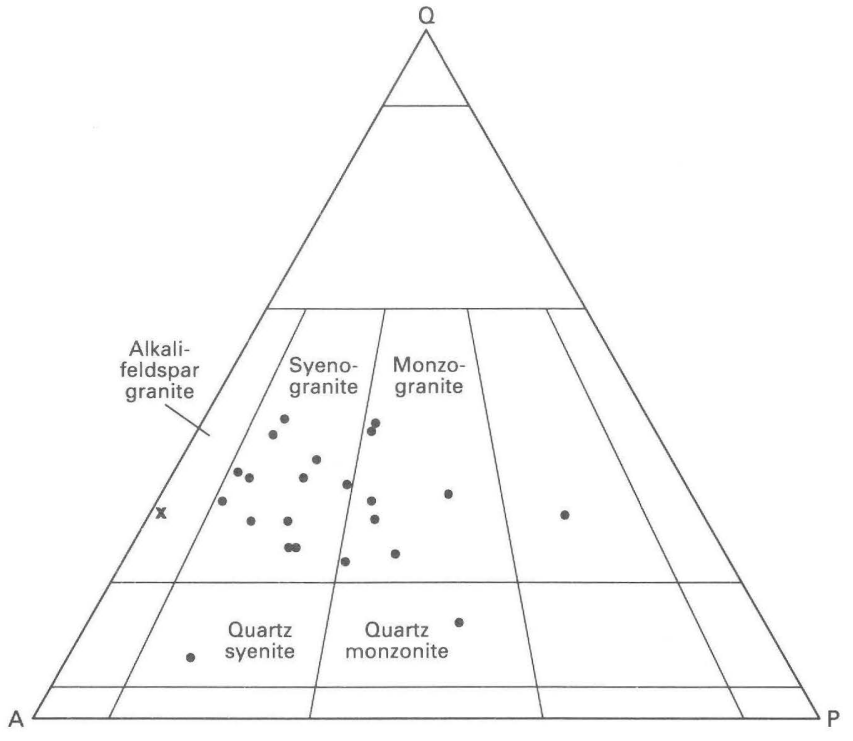

Figure D6. Modal Q-A-P (Streckeisen, 1976) plot of rocks of the Byram Intrusive Suite in the Greenwood Lake quadrangle, New York-New Jersey. Dated sample, x. Data from Hotz (1953), Offield (1967), and this study.

massive. It consists largely of quartz, microperthite, and oligoclase and as much as 13 percent hornblende (ferrohastingsite). The Storm King contains magnetite as well as minor amounts of apatite, zircon, sphene, tourmaline, and allanite.

Dodd (1965) mapped leucogranite that appears to be similar to the microperthite alaskite of the Byram. He also described bitoite granite that grades down into hornblende

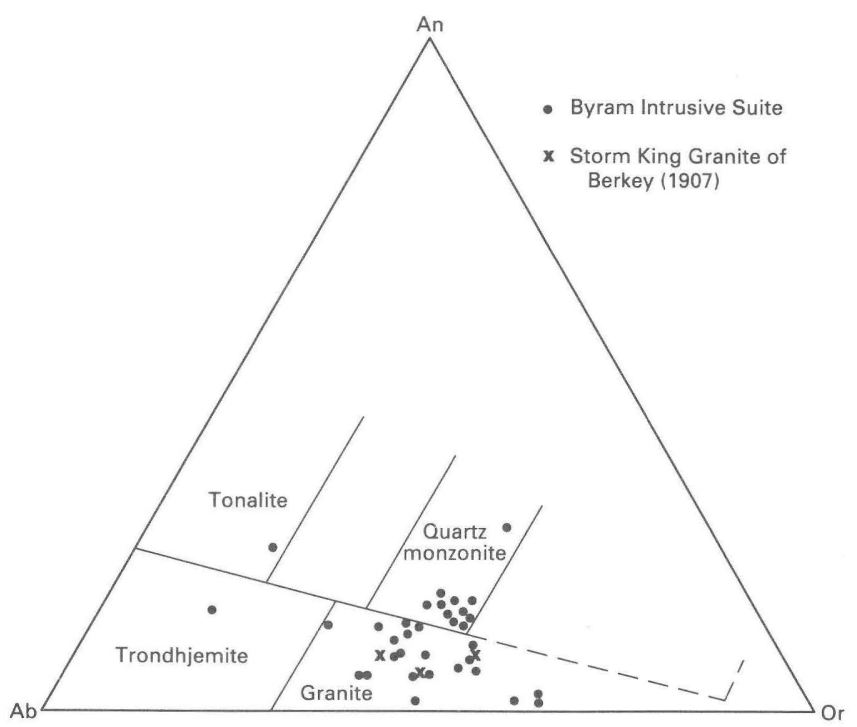

Figure D7. Normative Ab-An-Or plot (O'Connor, 1965) comparing rocks of the Byram Intrusive Suite with rocks of the Storm King Granite of Berkey (1907). Byram data from Drake and Volkert (chap. A, this vol.). Storm King data from Lowe (1950).

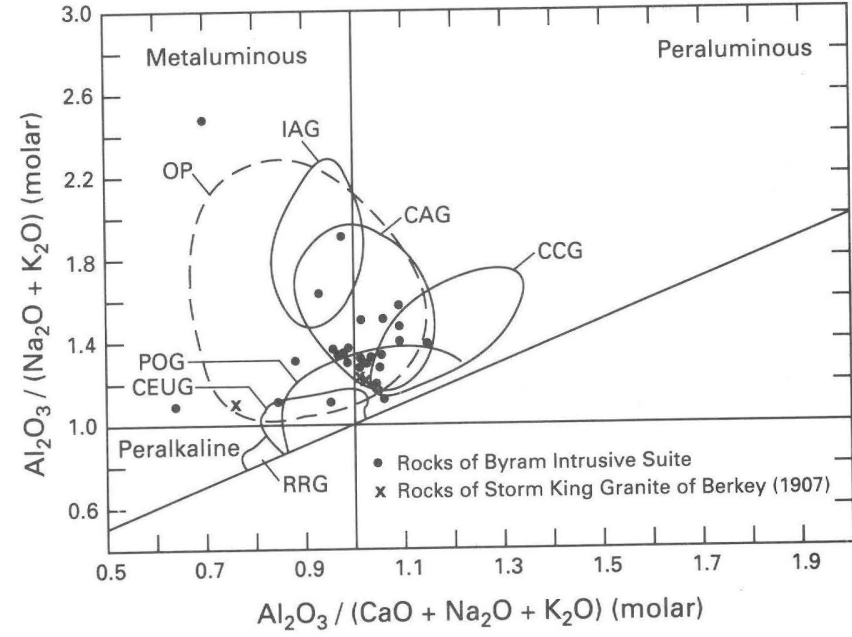

Figure D8. Shand's index showing different tectonic environments of granitoids (after Maniar and Piccoli, 1989). Fields are as follows: IAG, island arc granitoids; CAG, continental arc granitoids; CCG, continental collision granitoids; POG, postorogenic granites; RRG, rift-related granitoids; CEUG, continental epeirogenic uplift granitoids; and OP, oceanic plagiogranites. Data from Drake (1984), Drake and Volkert (chap. A, this vol.), and Lowe (1950).

granite and upward into biotite-quartz-feldspar gneiss, suggesting that it is a hybrid rock like the biotite granite of the Byram Intrusive Suite. Dodd (1965) also mapped rocks that appear to be amphibolite migmatite (fig. D15) similar to those described by Buckwalter (1962) and Drake and others (1961) to the west. He (Dodd, 1965) suggested alternatively that these rocks may be restite from which melt has been extracted, rather than migmatite to which melt has been added.

The Jaffes' description of hornblende granite in the Monroe quadrangle (fig. D3) is similar to that in the Popolopen Lake quadrangle. They also mapped small

Table D1. Molar $\mathrm{Al}_{2} \mathrm{O}_{3} /\left(\mathrm{CaO}+\mathrm{Na}_{2} \mathrm{O}+\mathrm{K}_{2} \mathrm{O}\right)$ ratios of rocks of the Byram Intrusive Suite and Storm King Granite of Berkey (1907).

[Data from Drake (1984), Drake and Volkert (chap. A, this vol.), and Lowe (1950)]

\begin{tabular}{cccc}
\hline $\begin{array}{c}\text { Byram Intrusive } \\
\text { Suite }\end{array}$ & $\begin{array}{r}\text { Byram- } \\
\text { Cont. }\end{array}$ & $\begin{array}{c}\text { Byram }- \\
\text { Cont. }\end{array}$ & $\begin{array}{c}\text { Storm King } \\
\text { Granite }\end{array}$ \\
\hline 0.99 & 1.01 & 0.84 & 1.02 \\
1.1 & .99 & .96 & 1.0 \\
1.09 & .96 & 1.06 & .77 \\
.98 & .98 & 1.05 & \\
.87 & 1.14 & 1.0 & \\
1.04 & 1.07 & 1.01 & \\
1.01 & 1.09 & 0.93 & \\
1.06 & 1.04 & 1.05 & \\
1.02 & .67 & & \\
\hline
\end{tabular}




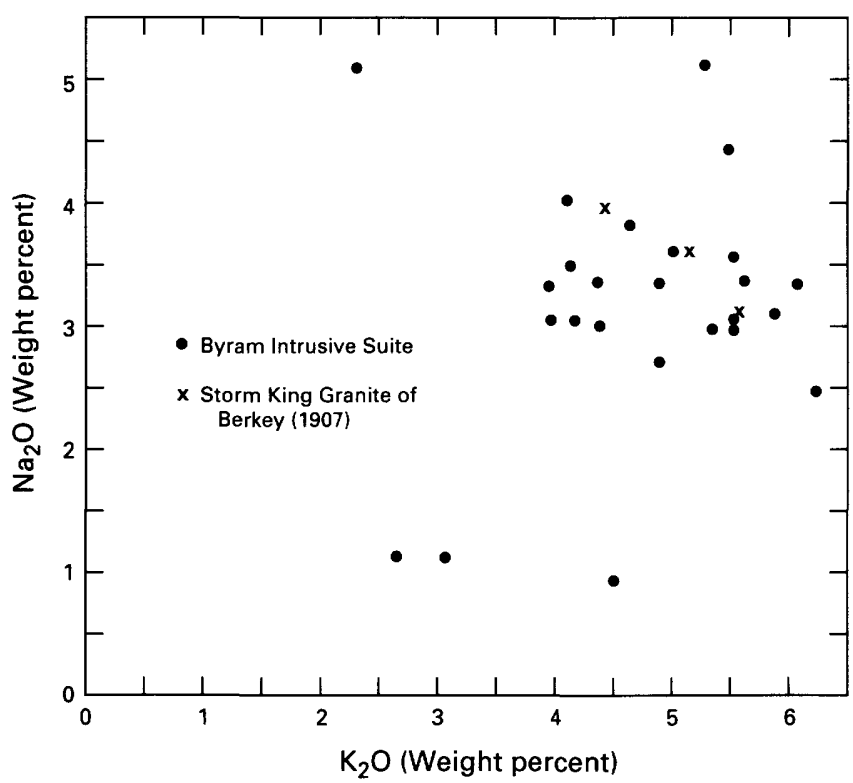

Figure D9. $\mathrm{Na}_{2} \mathrm{O}-\mathrm{K}_{2} \mathrm{O}$ plot of rocks of the Byram Intrusive Suite and Storm King Granite of Berkey (1907).

bodies of microcline alaskite that resembles the alaskite of the Byram except in its alkali feldspar. They (Jaffe and Jaffe, 1973) also described, but did not map, biotite granite and migmatitic rocks.

Modal data from the Popolopen Lake and Monroe quadrangles (fig. D3) are presented in figure D16. These data points have about the same distribution as those for

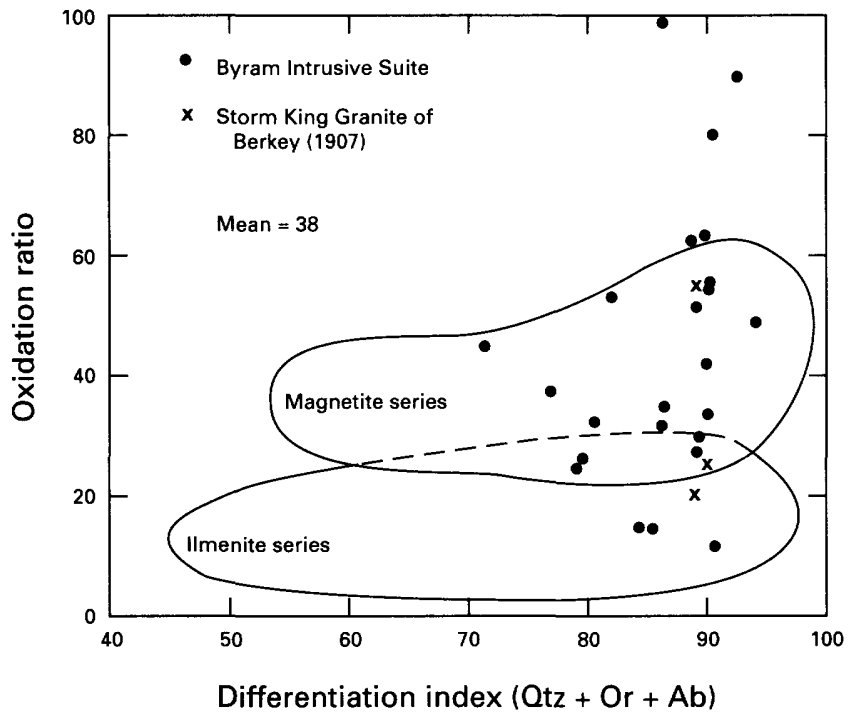

Figure D10. Oxidation ratio $\left(2 \mathrm{Fe}_{2} \mathrm{O}_{3} \times 100 / 2 \mathrm{Fe}_{2} \mathrm{O}_{3}+\mathrm{F}\right.$ eO in mole percent (Chinner, 1960) vs. differentiation index (Thornton and Tuttle, 1960) of rocks of the Byram Intrusive Suite and Storm King Granite of Berkey (1907). Magnetite and ilmenite series fields from Jin and others (1981). Data from Drake (1984), Drake and Volkert (chap. A, this vol.), and Lowe (1950).

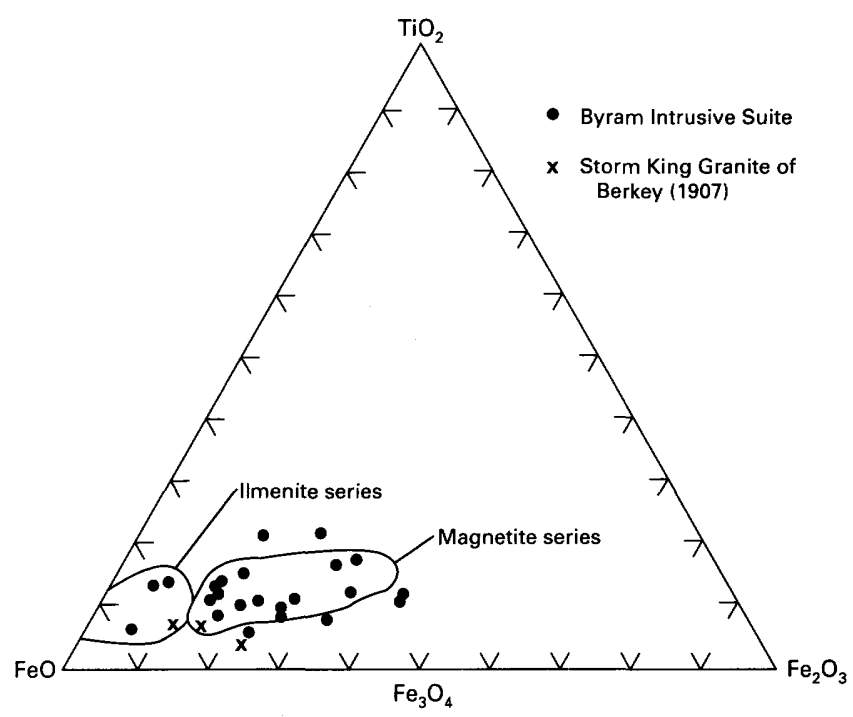

Figure D11. $\mathrm{TiO}_{2}-\mathrm{FeO}-\mathrm{Fe}_{2} \mathrm{O}_{3}$ (mole percent) diagram for rocks of the Byram Intrusive Suite and Storm King Granite of Berkey (1907) showing their oxidation state. Magnetite and ilmenite series fields from Jin and others (1981). Data from Drake (1984), Drake and Volkert (chap. A, this vol.), and Lowe (1950).

areas to the west (figs. D4, D6). Here, as in northern New Jersey and Pennsylvania, alkali-feldspar granite appears to be restricted to the interior parts of the granitic bodies.

The Storm King, like the Byram to the west, forms small to large, essentially conformable sheets within the hornblende granulite facies country rocks. The large Bear Mountain pluton (fig. D15) is a refolded sheet that is about $5 \mathrm{mi}$ long (Fisher and others, 1970) and about $1.25 \mathrm{mi}$ wide. The largest sheet in the Monroe quadrangle (fig. D3) is

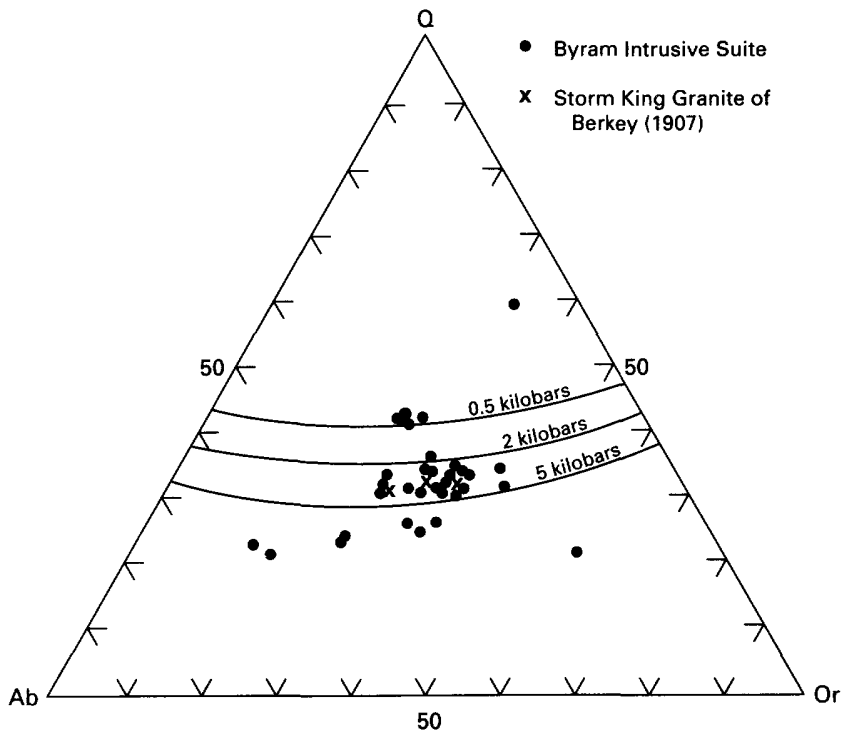

Figure D12. Normative Q-Ab-Or plot of rocks of the Byram Intrusive Suite and Storm King Granite of Berkey (1907) showing water pressures of $0.5,2$, and 5 kilobars. 


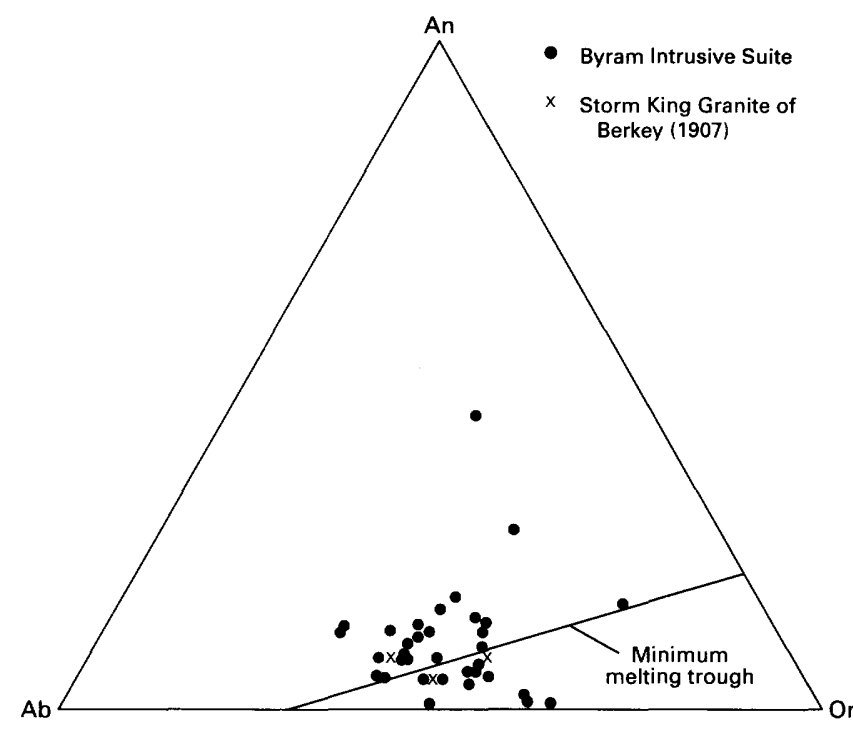

Figure D13. Rocks of the Byram Intrusive Suite and Storm King Granite of Berkey (1907) plotted on the $\mathrm{SiO}_{2}$ - saturated surface of the Or-Ab-An- $\mathrm{SiO}_{2}$ system at 5 kilobars $\mathrm{P}_{\mathrm{H}_{2} \mathrm{O}}$ projected onto the Or- $\mathrm{Ab}-\mathrm{An}$ face of the tetrahedron. Data from Drake $(1969,1984)$, Drake and Volkert (chap. A, this vol.), Lowe (1950), Sims (1958), and Young (1978). about $6 \mathrm{mi}$ long and about $0.5 \mathrm{mi}$ wide (Jaffe and Jaffe, 1973). Even larger sheets are shown by Fisher and others (1970), but this probably reflects the small-scale compilation, as the sheets mapped by Dodd (1965) and Jaffe and Jaffe (1973) are much smaller.

\section{Chemistry}

The only chemical data for the Storm King Granite that are available to us are the three analyses of Lowe (1950). These rocks are calc-alkaline (fig. D7). Two are slightly peraluminous, and a sample from the interior of the Bear Mountain pluton is metaluminous (fig. D8). The molecular ratios of $\mathrm{Al}_{2} \mathrm{O}_{3} /\left(\mathrm{CaO}+\mathrm{Na}_{2} \mathrm{O}+\mathrm{K}_{2} \mathrm{O}\right)$ of Storm King samples are 1.02 or less (table D1). Their $\mathrm{Na}_{2} \mathrm{O} / \mathrm{K}_{2} \mathrm{O}$ ratios are greater than 1 (fig. D9), and their oxidation state is high (figs. D10, D11). They are diopside normative (Lowe, 1950), and they plot at water pressures between 2 and $5 \mathrm{~kb}$ on the Q-Ab-Or diagram (fig. D12). They lie in the low-temperature trough on the An-Ab-Or plot (fig. D13), suggesting that they, like the Byram, solidified from magmatic fractional crystallization trending from granodioritic to alkali-feldspar granitic composition at temperatures of $650-750{ }^{\circ} \mathrm{C}$.



Figure D14. Concordia plot of U-Pb data from zircon from sample NY/GL 1-82. Diamonds are unabraded fractions (fractions 6-8, table D2); open circles are abraded fractions (fractions $1-5$, table D2); filled circles are used for regression forced through $0 \pm 50 \mathrm{Ma}$. MSWD, mean square of the weighted deviations (from the mean). See text for additional explanation. 
Table D2. U-Pb isotopic data from zircons from hornblende granite of the Byram Intrusive Suite [mg, milligrams; ppm, parts per million]

\begin{tabular}{|c|c|c|c|c|c|c|c|c|c|c|c|c|}
\hline \multirow{3}{*}{ Fraction $^{1}$} & \multirow{3}{*}{$\begin{array}{l}\text { Weight } \\
\text { (mg) }\end{array}$} & \multirow{2}{*}{\multicolumn{2}{|c|}{$\begin{array}{c}\text { Concentration } \\
(\mathrm{ppm})\end{array}$}} & \multicolumn{3}{|c|}{$\mathrm{Pb}$ composition ${ }^{2}$} & \multicolumn{3}{|c|}{ Ratios (percent error) ${ }^{3}$} & \multicolumn{3}{|c|}{ Ages $(M a)^{4}$} \\
\hline & & & & \multirow{2}{*}{$\frac{{ }^{206} \mathrm{~Pb}}{{ }^{204} \mathrm{~Pb}}$} & \multirow{2}{*}{$\frac{{ }^{206} \mathrm{~Pb}}{{ }^{207} \mathrm{~Pb}}$} & \multirow{2}{*}{$\frac{{ }^{206} \mathrm{~Pb}}{{ }^{208} \mathrm{~Pb}}$} & \multirow{2}{*}{$\frac{{ }^{206} \mathrm{~Pb}}{{ }^{238} \mathrm{U}}$} & \multirow{2}{*}{$\frac{{ }^{207} \mathrm{~Pb}}{{ }^{235} \mathrm{U}}$} & \multirow{2}{*}{$\frac{{ }^{207} \mathrm{~Pb}}{{ }^{206} \mathrm{~Pb}}$} & \multirow{2}{*}{$\frac{{ }^{206} \mathrm{~Pb}}{{ }^{238} \mathrm{U}}$} & \multirow{2}{*}{$\frac{{ }^{207} \mathrm{~Pb}}{{ }^{235} \mathrm{U}}$} & \multirow{2}{*}{$\frac{{ }^{207} \mathrm{~Pb}}{{ }^{206} \mathrm{~Pb}}$} \\
\hline & & $\mathrm{U}$ & $\mathrm{Pb}$ & & & & & & & & & \\
\hline $1(-100+150) \mathrm{DA}$ & 1.01 & 370.2 & 65.13 & 17523 & 13.038 & 12.472 & $0.1767(.13)$ & $1.849(.14)$ & $0.0759(.06)$ & 1049 & 1063 & 1092 \\
\hline $2(-150+200) \mathrm{DA}$ I & .22 & 345.1 & 52.69 & 4670.4 & 12.561 & 10.149 & $.1501(.16)$ & $1.585(.25)$ & $.0766(.19)$ & 902 & 964 & 1110 \\
\hline $3(-150+200) \mathrm{DA}$ II & .30 & 439.9 & 79.26 & 8961.2 & 12.943 & 12.077 & $.1803(.18)$ & $1.881(.19)$ & $.0757(.06)$ & 1068 & 1074 & 1086 \\
\hline $4(-150+200)$ DA III & .60 & 431.4 & 77.51 & 2354.9 & 12.307 & 11.054 & $.1770(.16)$ & $1.835(.18)$ & $.0752(.08)$ & 1050 & 1058 & 1074 \\
\hline $5(-200+250) \mathrm{DA}$ & .30 & 145.8 & 25.61 & 13905 & 13.051 & 12.058 & $.1759(.18)$ & $1.833(.26)$ & $.0756(.17)$ & 1045 & 1058 & 1084 \\
\hline $6(-100+150) \mathrm{D}$ & 1.22 & 506.3 & 84.77 & 215370 & 13.372 & 15.162 & $.1707(.21)$ & $1.759(.22)$ & $.0747(.07)$ & 1016 & 1030 & 1061 \\
\hline $7(-150+200) \mathrm{D}$ & .26 & 483.1 & 80.56 & 44461 & 13.315 & 14.983 & $.1698(.18)$ & $1.751(.19)$ & $.0748(.19)$ & 1011 & 1027 & 1063 \\
\hline $8(-400) \mathrm{NM}$ & 1.11 & 673.2 & 108.3 & 10893 & 13.345 & 15.100 & $.1637(.14)$ & $1.662(.16)$ & $.0736(.06)$ & 977 & 994 & 1031 \\
\hline
\end{tabular}

${ }^{1}$ Abbreviations: D, diamagnetic; A, abraded; NM, nonmagnetic.

${ }^{2}$ Blank and fractionation corrected. Blank lead composition is $1: 18.7: 15.6: 37.2$.

32 sigma errors (expressed as percent) in parentheses.

${ }^{4}$ Ages corrected for common lead using appropriate values from Stacey and Kramers (1975).

Constants: ${ }^{235} \mathrm{U}=9.8485 \mathrm{E}-10 / \mathrm{yr} ;{ }^{238} \mathrm{U}=1.55125 \mathrm{E}-10 / \mathrm{yr} ;{ }^{238} \mathrm{U} /{ }^{235} \mathrm{U}=137.88$ (Steiger and Jäger, 1977).

Available chemical data are similar to those of the Byram, as are other, more abundant Storm King data presented in Rankin and others (in press). The Storm King Granite, then, is an I-type granite derived from the melting of an igneous source (Chappell and White, 1974).

\section{TECTONIC ENVIRONMENT}

Maniar and Piccoli (1989) have recently developed criteria to determine the tectonic environment in which a granitoid was generated. The most critical factors for rocks like the Byram Intrusive Suite and Storm King Granite are their position on the Shand's index plot (fig. D8) and their molar ratios of $\mathrm{Al}_{2} \mathrm{O}_{3} /\left(\mathrm{CaO}+\mathrm{Na}_{2} \mathrm{O}+\mathrm{K}_{2} \mathrm{O}\right)$. It can be seen that the bulk of the Byram and Storm King analyses plot within the continental arc granite field (fig. D8). There is an overlap between this field and that of continental collision granitoids, but rocks of these two environments can be separated on the basis of their molar ratios of $\mathrm{Al}_{2} \mathrm{O}_{3} /\left(\mathrm{CaO}+\mathrm{Na}_{2} \mathrm{O}+\mathrm{K}_{2} \mathrm{O}\right.$ ) (Maniar and Piccoli, 1989). Continental arc granites have ratios less than 1.05 , whereas continental collision granites have ratios greater than 1.15. It is not possible to discriminate between the environments that have ratios between 1.05 and 1.15. Most of the Byram and Storm King samples have ratios less than 1.05 , and their highest ratio is 1.1 (table D1). It is concluded, therefore, that the Byram Intrusive Suite and Storm King Granite were generated in a continental arc setting. This conclusion is supported by their I-type nature and their assignment to the magnetite-series, which shows that they crystallized from highly oxidized magmas (Ishihara, 1977; Wones, 1981). Such magmas must come from an oxidized source, and a carbon-free ocean floor is a prime candidate for such a source. Such rocks must have been generated at an ocean-continental convergent margin along which a continental arc developed above a downgoing oceanic slab. It is difficult to determine at this time where the ocean was during Grenville time, but it was probably east of the Reading Prong (present direction), as granitoids similar to the Byram and Storm King occur in the external basement massifs and Adirondack Highlands to the north (Drake, 1984; Drake and Ratcliffe, in Rankin and others, in press; Drake and Volkert, chap. A, this vol.). Such rocks are not known in the Honey Brook Uplands or internal basement massifs to the south (Crawford and Hoersch, 1984; Drake, 1984; Drake and Ratcliffe, in Rankin and others, in press). Metamorphosed volcanic rocks, however, are abundant in the internal basement massifs that project to the east of the Reading Prong.

\section{CONCLUSIONS}

Rocks of the Byram Intrusive Suite and the Storm King Granite are quite similar in appearance, petrography, chemistry, and mode of emplacement. They differ in age, however, by $44 \mathrm{~m} . \mathrm{y}$. Taking the geochronologic data at face value suggests that granite emplacement occurred over this time span. Younger granitoids in continental arc settings such as the coastal batholith of Peru (Pitcher, 1978) and the Sierra Nevada batholith of California (Bateman and Clark, 1974) were emplaced over periods of $70 \mathrm{~m} . \mathrm{y}$. and 60-80 m.y. respectively; therefore a period of intrusion of $44 \mathrm{~m} . \mathrm{y}$. is not unreasonable. Some support for this concept is found in the work of Buddington and Leonard (1953), who found that the quartz- and potash-rich (alkali-feldspar granite) phases of the hornblende granite in the Adirondacks 


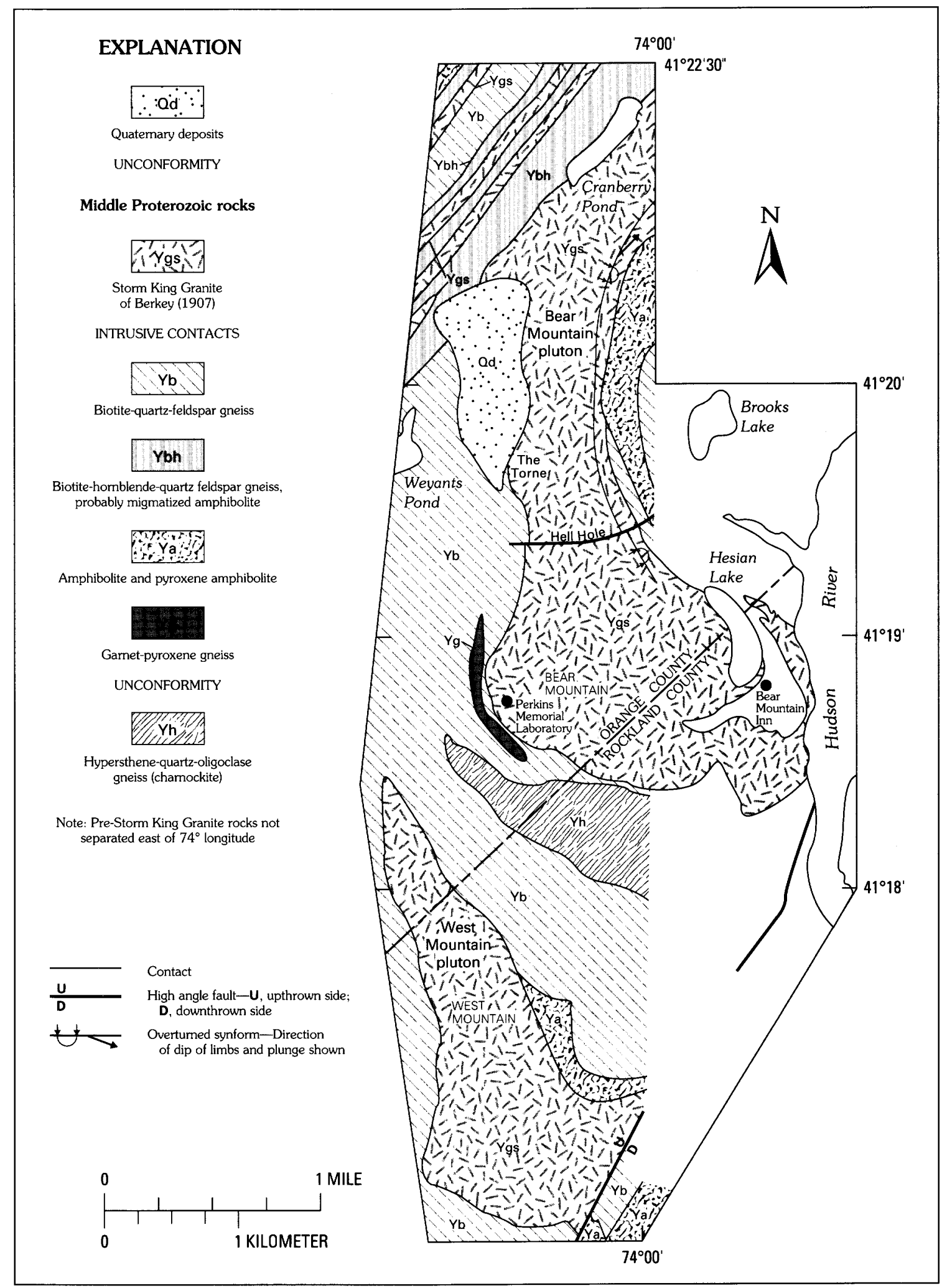

Figure D15. Generalized geologic map of the Bear Mountain area, New York. Data from Dodd (1965) and Lowe (1950). 




Figure D16. Modal Q-A-P (Streckeisen, 1976) plot of hornblende granite from the Hudson Highlands. (Storm King Granite is usage of Berkey, 1907.) Data from Dodd (1965): + , average of five samples from interior of West Mountain pluton of Storm King Granite, a, average of four samples from near contacts of West Mountain pluton of Storm King Granite; $x$, average of two samples from interior of Bear Mountain pluton of Storm King Granite; $\square$, average of four samples from near contacts of Bear Mountain pluton of Storm King Granite; and o, other samples of hornblende granite from the Popolopen Lake quadrangle, New York. Data from Monroe quadrangle, New York, •, from Jaffe and Jaffe (1973).

were younger differentiates of the same magma that produced the normal syeno- and monzogranites. The dated sample of Byram is an alkali-feldspar granite, whereas many of the other rocks are syeno- or monzogranites. On the other hand, zircons from the Storm King may, like the Byram, include an inherited element, and the rocks may actually be more similar in age. In any case, our current level of knowledge suggests that the Byram Intrusive Suite and Storm King Granite were generated in a continental arc setting, that magmatism extended from about $1134 \mathrm{Ma}$ to $1090 \mathrm{Ma}$, and that Grenville deformation extended from at least $1134 \mathrm{Ma}$ to $1020 \mathrm{Ma}$, when the postkinematic Mount Eve Granite was intruded.

\section{REFERENCES CITED}

Baker, D.R., and Buddington, A.F., 1970, Geology and magnetite deposits of the Franklin quadrangle and part of the Hamburg quadrangle, New Jersey: U.S. Geological Survey Professional Paper 638, 73 p.

Bateman, P.C., and Clark, L.D., 1974, Stratigraphic and structural setting of the Sierra Nevada batholith, California: Pacific Geology, v. 8, p. 79-89.
Berkey, C.P., 1907, Structural and stratigraphic features of the basal gneisses of the Highlands: New York State Museum Bulletin 107, p. 361-387.

Berkey, C.P., and Rice, Marion, 1919, Geology of the West Point quadrangle, New York: New York State Museum Bulletins 225-226, $179 \mathrm{p}$.

Buckwalter, T.V., 1962, The Precambrian geology of the Reading 15-minute quadrangle: Pennsylvania Geological Survey, 4th ser., Progress Report 161, 49 p.

Buddington, A.F., and Leonard, B.F., 1953, Chemical petrology and mineralogy of hornblendes in northwest Adirondack granitic rocks: American Mineralogist, v. 38, p. 891-902.

Chappell, B.W., and White, A.J.R., 1974, Two contrasting granite types: Pacific Geology, v. 8, p. 173-174.

Chinner, G.A., 1960, Pelitic gneisses with varying ferrous/ferric ratios from Glen Clova, Angus, Scotland: Journal of Petrology, v. 1, p. 178-217.

Crawford, W.A., and Hoersch, A.L., 1984, The geology of the Honey Brook Upland, southeastern Pennsylvania, in Bartholomew, M.J., ed., The Grenville event in the Appalachians and related topics: Geological Society of America Special Paper 194, p. 111-125.

Dallmeyer, R.D., 1972, Precambrian structural history of the Hudson Highlands, near Bear Mountain, New York: Geological Society of America Bulletin, v. 83, p. 895-904.

Dodd, R.T., 1965, Precambrian geology of the Popolopen Lake quadrangle, southeastern New York: New York State Museum and Science Service Map and Chart Series 6, $39 \mathrm{p}$.

Drake, A.A., Jr., 1969, Precambrian and Lower Paleozoic geology of the Delaware Valley, New Jersey-Pennsylvania, in Subitzky, Seymour, ed., Geology of selected areas in New Jersey and eastern Pennsylvania and Guidebook of excursions: New Brunswick, N.J., Rutgers University Press, p. 51-131.

1984, The Reading Prong of New Jersey and eastern Pennsylvania-An appraisal of rock relations and chemistry of a major Proterozoic terrane in the Appalachians, in Bartholomew, M.J., ed., The Grenville event in the Appalachians and related topics: Geological Society of America Special Paper 194, p. 75-109.

1990, The regional geologic setting of the FranklinSterling Hill district, Sussex County, New Jersey, in Character and Origin of the Franklin-Sterling Hill orebodies: Bethlehem, Pa., Franklin-Ogdensburg Mineralogical Society symposium, Lehigh University, Proceedings, p. 17-34.

in press a, Precambrian and lower Paleozoic metamorphic and igneous rocks of South Mountain and the Reading Prong, in Shultz, C.H., ed., The geology of Pennsylvania: Harrisburg, Pa., Pittsburgh Geological Society.

-in press b, Structural geology and tectonics of South Mountain and the Reading Prong, in Shultz, C.H., ed., The geology of Pennsylvania: Harrisburg, Pa., Pittsburgh Geological Society.

Drake, A.A., Jr., Aleinikoff, J.N., and Volkert, R.A., 1990, Synand post-kinematic granites of the New Jersey Highlands: Geological Society of America Abstracts with Programs, v. 22 , p. 12.

Drake, A.A., Jr., Hall, L.M., and Nelson, A.E., 1988, Basement and basement-cover relation map of the Appalachian orogen 
in the United States: U.S. Geological Survey Miscellaneous Investigations Map I-1655, scale 1:1,000,000.

Drake, A.A., Jr., Kastelic, R.L., Jr., and Lyttle, P.T., 1985, Geologic map of the eastern parts of the Belvidere and Portland quadrangles, Warren County, New Jersey: U.S. Geological Survey Miscellaneous Investigations Map I-1530, scale 1:24,000.

Drake, A.A., Jr., McLaughlin, D.B., and Davis, R.E., 1961, Geology of the Frenchtown quadrangle, New JerseyPennsylvania: U.S. Geological Survey Geologic Quadrangle Map GQ-133, scale 1:24,000.

Fisher, D.W., Isachsen, Y.W., and Rickard, L.V., 1970, Geologic map of New York State, Lower Hudson sheet: New York State Museum and Science Service Map and Chart Series 15, scale 1:250,000.

Hague, J.M., Baum, J.L., Herrman, L.A., and Pickering, R.J., 1956, Geology and structure of the Franklin-Sterling area, New Jersey: Geological Society of America Bulletin, v. 67, p. $434-474$.

Helenek, H.L., 1971, An investigation of the origin, structure, and metamorphic evolution of major rock units in the Hudson Highlands: Unpub. Ph.D. thesis, Brown University, 244 p.

Helenek, H.L., and Mose, D.G., 1984, Geology and geochronology of Canada Hill Granite and its bearing on the timing of the Grenvillian events in the Hudson Highlands, New York, in Bartholomew, M.J., ed., The Grenville event in the Appalachians and related topics: Geological Society of America Special Paper 194, p. 57-73.

Hotz, P.E., 1953, Magnetite deposits of the Sterling Lake, N.Y.-Ringwood, N.J., area: U.S. Geological Survey Bulletin 982-F, p. 153-244.

Ishihara, S., 1977, The magnetite-series and ilmenite-series granitic rocks: Mining Geology, v. 27, p. 293-305.

Jaffe, H.W., and Jaffe, E.B., 1973, Bedrock geology of the Monroe quadrangle, Orange County, New York: New York State Museum and Science Service Map and Chart Series 20, $74 \mathrm{p}$.

Jin, M-S, Kim, S-Y, and Lee, J-S, 1981, Granitic magmatism and associated mineralization in the Gyeongsand Basin, Korea: Mining Geology, v. 31, p. 245-260.

Kastelic, R.L., Jr., 1980, Precambrian geology and magnetite deposits of the New Jersey Highlands in Warren County, New Jersey: U.S. Geological Survey Open-File Report 80-789, 140 p.

Lowe, K.E., 1950, Storm King Granite at Bear Mountain, N.Y.: Geological Society of America Bulletin, v. 61, p. 137-190.

Maniar, P.D., and Piccoli, P.M., 1989, Tectonic discrimination of granitoids: Geological Society of America Bulletin, v. 101 , p. $635-643$.

O'Connor, J.T., 1965, A classification for quartz-rich igneous rocks based on feldspar ratios: U.S. Geological Survey Professional Paper 525-B, p. B79-B84.

Offield, T.W., 1967, Bedrock geology of the Goshen-Greenwood Lake area, New York: New York Museum and Science Service Map and Chart Series 9, 78 p.

Pitcher, W.S., 1978, The anatomy of a batholith: Journal of the Geological Society of London, v. 135, p. 157-182.
Rankin, D.W., Drake, A.A., Jr., Glover, Lynn, III, Goldsmith, Richard, Hall, L.M., Murray, D.P., Ratcliffe, N.M., Read, J.F., Secor, D.T., Jr., and Stanley, R.S., 1989, Pre-orogenic terranes, in Hatcher, R.D., Jr., Thomas, W.A., and Viele, G.W., eds., The Appalachian-Ouachita Orogen, U.S. (The Geology of North America, v. F-2): Boulder, Colo., Geological Society of America, p. 7-100.

Rankin, D.W., Drake, A.A., Jr., and Ratcliffe, N.M., 1989 , Geologic map of the U.S. Appalachians showing the Laurentian margin and Taconic orogen, in Hatcher, R.D., Jr., Thomas, W.A., and Viele, G.W., eds., The AppalachianOuachita Orogen, U.S. (The Geology of North America, v. F-2): Boulder, Colo., Geological Society of America, scale $1: 1,500,000$.

-in press, Proterozoic North American (Laurentian) rocks of the Appalachian orogen, in Reed, J.C., Jr., Bickford, M.E., Houston, R.S., Link, P.K., Rankin, D.W., Sims, P.K., and Van Schmus, W.R., Precambrian: Conterminous U.S. (The Geology of North America, v. C-2): Boulder, Colo., Geological Society of America.

Ratcliffe, N.M., Armstrong, R.L., Chai, B.H.T., and Seneschel, R.G., 1972, K-Ar and Rb-Sr geochronology of the Canopus pluton, Hudson Highlands, New York: Geological Society of America Bulletin, v. 83, p. 523-530.

Sims, P.K., 1958, Geology and magnetite deposits of the Dover district, Morris County, New Jersey: U.S. Geological Survey Professional Paper 287, 162 p.

Smith, B.L., 1969, The Precambrian geology of the central and northeastern parts of the New Jersey Highlands, in Subitzky, Seymour, ed., Geology of selected areas in New Jersey and eastern Pennsylvania and Guidebook of excursions: New Brunswick, N.J., Rutgers University Press, p. 35-47.

Stacey, J.S., and Kramers, J.D., 1975, Approximation of terrestrial lead isotope evolution by a two-stage model: Earth and Planetary Science Letters, v. 26, p. 207-226.

Steiger, R.H., and Jäger, Emile, 1977, Subcommission of geochronology, Convention on the use of decay constants in geo- and cosmochronology: Earth and Planetary Science Letters, v. 36, p. 359-362.

Streckeisen, Albert, 1976, To each plutonic rock its proper name: Earth Science Reviews, v. 12, p. 1-33.

Thornton, C.P., and Tuttle, O.F., 1960, Chemistry of igneous rocks-I, Differentiation index: American Journal of Science, v. 258, p. 664-684.

Tuttle, O.F., and Bowen, N.L., 1958, Origin of granite in the light of experimental studies in the system $\mathrm{NaAlSi}_{3} \mathrm{O}_{8}$ $\mathrm{KAlSi}_{3} \mathrm{O}_{8}-\mathrm{SiO}_{2}-\mathrm{H}_{2} \mathrm{O}$ : Geological Society of America Memoir $74,153 \mathrm{p}$.

Wones, D.R., 1981, Mafic silicates as indicators of intensive variables in granitic magmas: Mining Geology, v. 31, p. 191-212.

Young, D.A., 1971, Precambrian rocks of the Lake Hopatcong area, New Jersey: Geological Society of America Bulletin, v. 82 , p. $143-158$.

1978, Precambrian salic intrusive rocks of the Reading Prong: Geological Society of America Bulletin, v. 89, p. $1502-1514$. 


\section{SELECTED SERIES OF U.S. GEOLOGICAL SURVEY PUBLICATIONS}

\section{Periodicals}

Earthquakes \& Volcanoes (issued bimonthly).

Preliminary Determination of Epicenters (issued monthly).

\section{Technical Books and Reports}

Professional Papers are mainly comprehensive scientific reports of wide and lasting interest and importance to professional scientists and engineers. Included are reports on the results of resource studies and of topographic, hydrologic, and geologic investigations. They also include collections of related papers addressing different aspects of a single scientific topic.

Bulletins contain significant data and interpretations that are of lasting scientific interest but are generally more limited in scope or geographic coverage than Professional Papers. They include the results of resource studies and of geologic and topographic investigations, as well as collections of short papers related to a specific topic.

Water-Supply Papers are comprehensive reports that present significant interpretive results of hydrologic investigations of wide interest to professional geologists, hydrologists, and engineers. The series covers investigations in all phases of hydrology, including hydrogeology, availability of water, quality of water, and use of water.

Circulars present administrative information or important scientific information of wide popular interest in a format designed for distribution at no cost to the public. Information is usually of short-term interest.

Water-Resources Investigations Reports are papers of an interpretive nature made available to the public outside the formal USGS publications series. Copies are reproduced on request unlike formal USGS publications, and they are also available for public inspection at depositories indicated in USGS catalogs.

Open-File Reports include unpublished manuscript reports, maps, and other material that are made available for public consultation at depositories. They are a nonpermanent form of publication that may be cited in other publications as sources of information.

\section{Maps}

Geologic Quadrangle Maps are multicolor geologic maps on topographic bases in 7.5- or 15-minute quadrangle formats (scales mainly $1: 24,000$ or $1: 62,500$ ) showing bedrock, surficial, or engineering geology. Maps generally include brief texts; some maps include structure and columnar sections only.

Geophysical Investigations Maps are on topographic or planimetric bases at various scales; they show results of surveys using geophysical techniques, such as gravity, magnetic, seismic, or radioactivity, which reflect subsurface structures that are of economic or geologic significance. Many maps include correlations with the geology.

Miscellaneous Investigations Series Maps are on planimetric or topographic bases of regular and irregular areas at various scales; they present a wide variety of format and subject matter. The series also includes 7.5-minute quadrangle photogeologic maps on planimetric bases that show geology as interpreted from aerial photographs. Series also includes maps of Mars and the Moon.
Coal Investigations Maps are geologic maps on topographic or planimetric bases at various scales showing bedrock or surficial geology, stratigraphy, and structural relations in certain coal-resource areas.

Oil and Gas Investigations Charts show stratigraphic information for certain oil and gas fields and other areas having petroleum potential.

Miscellaneous Field Studies Maps are multicolor or blackand-white maps on topographic or planimetric bases on quadrangle or irregular areas at various scales. Pre-1971 maps show bedrock geology in relation to specific mining or mineral-deposit problems; post-1971 maps are primarily black-and-white maps on various subjects such as environmental studies or wilderness mineral investigations.

Hydrologic Investigations Atlases are multicolored or blackand-white maps on topographic or planimetric bases presenting a wide range of geohydrologic data of both regular and irregular areas; principal scale is $1: 24,000$, and regional studies are at 1:250,000 scale or smaller.

\section{Catalogs}

Permanent catalogs, as well as some others, giving comprehensive listings of U.S. Geological Survey publications are available under the conditions indicated below from the U.S. Geological Survey, Books and Open-File Reports Section, Federal Center, Box 25425, Denver, CO 80225. (See latest Price and Availability List.)

"Publications of the Geological Survey, 1879-1961" may be purchased by mail and over the counter in paperback book form and as a set of microfiche.

"Publications of the Geological Survey, 1962-1970" may be purchased by mail and over the counter in paperback book form and as a set of microfiche.

"Publications of the U.S. Geological Survey, 1971-1981" may be purchased by mail and over the counter in paperback book form (two volumes, publications listing and index) and as a set of microfiche.

Supplements for 1982, 1983, 1984, 1985, 1986, and for subsequent years since the last permanent catalog may be purchased by mail and over the counter in paperback book form.

State catalogs, "List of U.S. Geological Survey Geologic and Water-Supply Reports and Maps For (State)," may be purchased by mail and over the counter in paperback booklet form only.

"Price and Availability List of U.S. Geological Survey Publications," issued annually, is available free of charge in paperback booklet form only.

Selected copies of a monthly catalog "New Publications of the U.S. Geological Survey" are available free of charge by mail or may be obtained over the counter in paperback booklet form only. Those wishing a free subscription to the monthly catalog "New Publications of the U.S. Geological Survey" should write to the U.S. Geological Survey, 582 National Center, Reston, VA 22092.

Note. - Prices of Government publications listed in older catalogs, announcements, and publications may be incorrect. Therefore, the prices charged may differ from the prices in catalogs, announcements, and publications. 


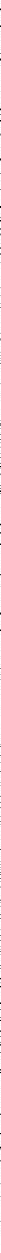

